\title{
Energy Management Curriculum Starter Kit
}

\author{
N. L. Moore, Project Manager
}

February 1987

Prepared by W. C. Turner, Consultant, for Pacific Northwest Laboratory under Contract DE-AC06-76RLO 1830 with the U.S. Department of Energy

Pacific Northwest Laboratory

Operated for the U.S. Department of Energy by Battelle Memorial Institute 


\section{DISCLAIMER}

This report was prepared as an account of work sponsored by an agency of the United States Government. Neither the United States Government nor any agency thereof, nor Battelle Memorial Institute, nor any of their employees, makes any warranty, expressed or implied, or assumes any legal liability or responsibility for the accuracy, completeness, or usefulness of any information, apparatus, product, or process disclosed, or represents that its use would not infringe privately owned rights. Reference herein to any specific commercial product, process, or service by trade name, trademark, manufacturer, or otherwise, does not necessarily constitute or imply its endorsement, recommendation, or favoring by the United States Government of any agency thereof, or Battelle Memorial Institute. The views and opinions of authors expressed herein do not necessarly state or reflect those of the United States Government or any agency thereof, or Battelle Memorial Institute.

\section{PACIFIC NORTHWEST LABORATORY operated by BATTELLE MEMORIAL INSTITUTE for the UNITED STATES DEPARTMENT OF ENERGY under Contract DE-AC06-76RLO 1830}

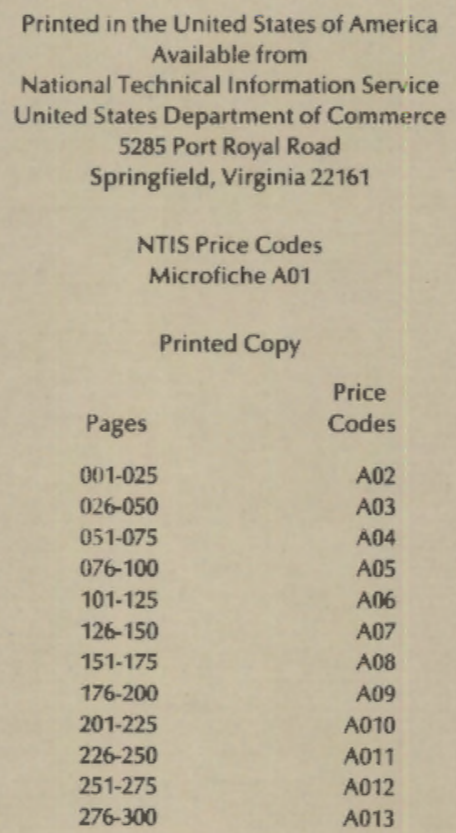


PNL -6156

UC $-95 f$

Subcontractor Report

ENERGY MANAGEMENT CURRICULUM STARTER KIT

\author{
W. C. Turner \\ Consultant \\ Stillwater, Oklahoma
}

February 1987

Prepared by W. C. Turner, Consultant, for Pacific Northwest Laboratory under Contract DE-AC06-76RLO 1830 with the U.S. Department of Energy

Pacific Northwest Laboratory

Richland, Washington 99352 


\section{$\bullet$}




\section{PREFACE}

The Energy Management Curriculum Starter Kit was designed to help engineering educators develop and teach energy management courses. Montana State University and OKlahoma State University courses are embodied in the model curriculum given. The curricula offered at many other universities throughout the United States are also presented.

The kit was designed specifically to train engineering students to be good energy managers. Courses at both the undergraduate and postgraduate level are presented. It is hoped that professors reading this text can use this kit to design new courses. Most professors will probably start close to this model and deviate more as experience is gained.

We sincerely hope that this kit helps in the teaching of these badly needed courses. Suggestions to improve this kit are welcome and will be examined sincerely. Alternative course outlines or other suggestions will be made available by W. C. Turner as long as feasible. Inquiries or suggestions may be addressed to:

Dr. Wayne C. Turner

Industrial Engineering and Management

Oklahoma State University

Stillwater, Oklahoma 74078

Work (405) 624-6055

Home (405) 377-0592 
-

.

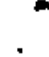

$\bullet$

. 
SUMMARY

The Energy Management Curriculum Starter Kit was developed as a cooperative effort by Montana State University, Oklahoma State University, the United States Department of Energy, and Pacific Northwest Laboratory. This research first surveyed a set of existing courses and potential textbooks. Then course syllabi for an undergraduate and a graduate course in energy management were developed. The laboratory exercises were developed as a valuable part of the study; "hands-on" laboratory experience is badly needed in energy management education. An annotated bibliography of the potential textbooks was also developed.

The undergraduate model course was designed for engineering students in their junior or senior year and will require a sound engineering science basis. The graduate level class was designed to be presented at the Masters level, and the undergraduate course would be required as a prerequisite.

In addition to the model course, syllabi from numerous engineering colleges are shown. Programs at the associate-, undergraduate-, and graduate level are represented.

The researchers recommend a follow-up study in a few years to assess the maturing of energy management education and revising of the model courses. A forum for energy management educators might be needed at that time. 
$\therefore$

$\bullet$ 


\section{ACKNOWLEDGMENTS}

This project could not have been completed without the help of the United States Department of Energy and Pacific Northwest Laboratory. Energy management owes them a word of thanks. Special thanks to Mr. Nick Knight, a graduate student at Montana State University. 
-

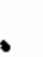

. 


\section{CONTENTS}

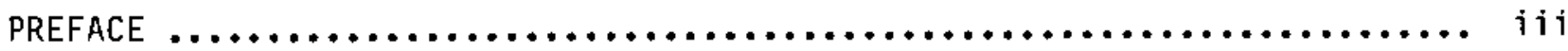

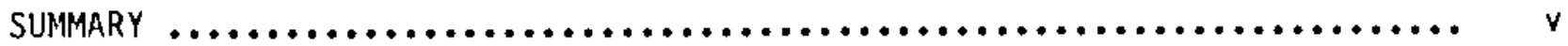

ACKNOWLEDGMENTS $\ldots \ldots \ldots \ldots \ldots \ldots \ldots \ldots \ldots \ldots \ldots \ldots \ldots \ldots \ldots \ldots \ldots \ldots \ldots \ldots \ldots$

ENERGY MANAGEMENT CURRICULUM STARTER KIT $\ldots \ldots \ldots \ldots \ldots \ldots \ldots \ldots \ldots \ldots \ldots \ldots \ldots$

INTRODUCTION $\ldots \ldots \ldots \ldots \ldots \ldots \ldots \ldots \ldots \ldots \ldots \ldots \ldots \ldots \ldots \ldots \ldots \ldots \ldots \ldots \ldots \ldots$

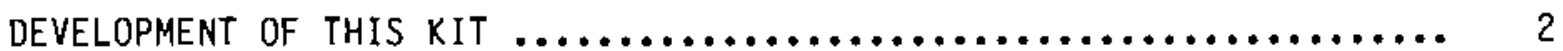

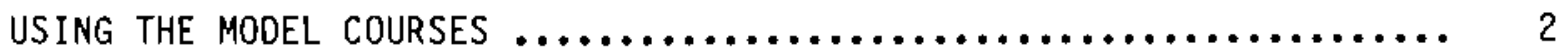

OTHER COURSE CURRICULA ............................ 3

CONTINUING EDUCATION PROGRAMS $\ldots \ldots \ldots \ldots \ldots \ldots \ldots \ldots \ldots \ldots \ldots \ldots \ldots \ldots \ldots \ldots$

MODEL ENERGY MANAGEMENT COURSE $\ldots \ldots \ldots \ldots \ldots \ldots \ldots \ldots \ldots \ldots \ldots \ldots \ldots \ldots \ldots \ldots \ldots \ldots . \ldots$

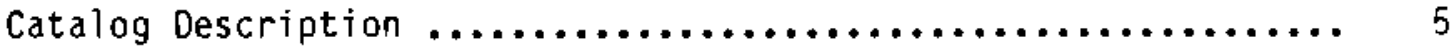

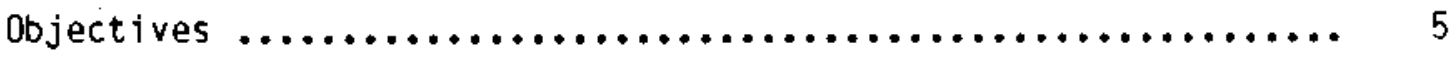

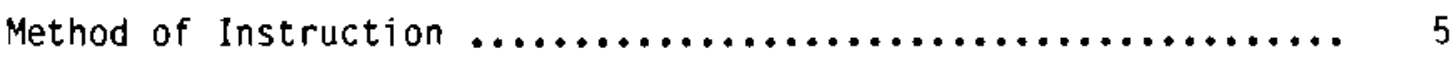

ENERgy MANAGEMENT LabORATORIES $\ldots \ldots \ldots \ldots \ldots \ldots \ldots \ldots \ldots \ldots \ldots \ldots \ldots \ldots \ldots \ldots \ldots . \ldots . \ldots \ldots$

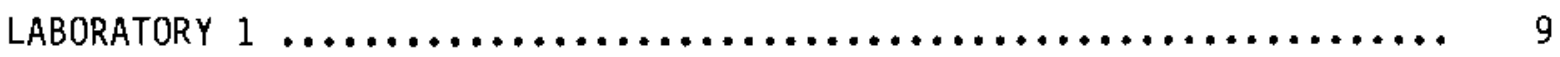

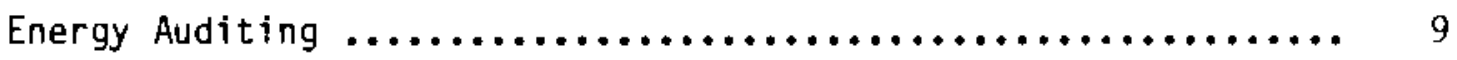

References $\ldots \ldots \ldots \ldots \ldots \ldots \ldots \ldots \ldots \ldots \ldots \ldots \ldots \ldots \ldots \ldots \ldots \ldots \ldots \ldots$

Electric Rate Schedules $\ldots \ldots \ldots \ldots \ldots \ldots \ldots \ldots \ldots \ldots \ldots \ldots \ldots \ldots$

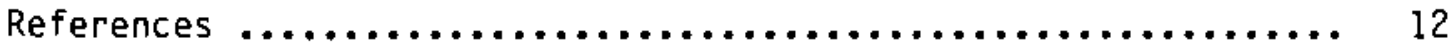

Water and Natural Gas Rate Schedules ................... 12

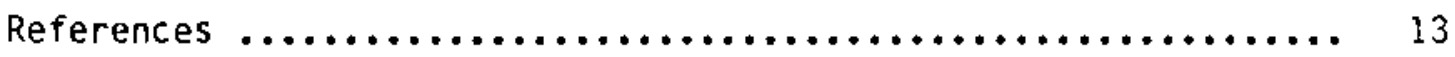

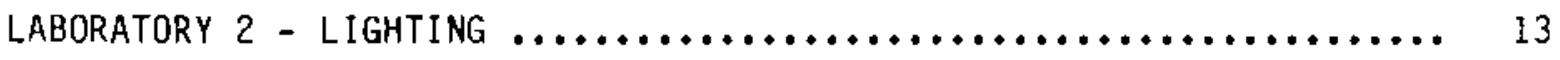

0iscussion $\ldots \ldots \ldots \ldots \ldots \ldots \ldots \ldots \ldots \ldots \ldots \ldots \ldots \ldots \ldots \ldots \ldots \ldots \ldots$

References $\ldots \ldots \ldots \ldots \ldots \ldots \ldots \ldots \ldots \ldots \ldots \ldots \ldots \ldots \ldots \ldots \ldots \ldots \ldots \ldots$ 


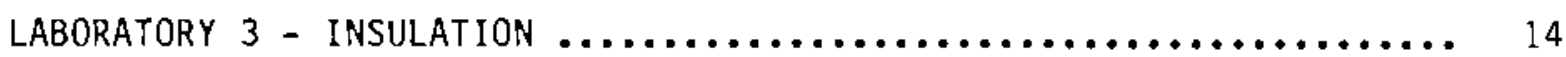

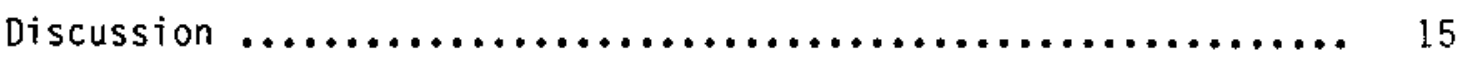

References $\ldots \ldots \ldots \ldots \ldots \ldots \ldots \ldots \ldots \ldots \ldots \ldots \ldots \ldots \ldots \ldots \ldots \ldots \ldots \ldots \ldots$

LABORATORY 4 - ELECTRICAL ENERGY MANAGEMENT $\ldots \ldots \ldots \ldots \ldots \ldots \ldots \ldots \ldots$

Discussion $\ldots \ldots \ldots \ldots \ldots \ldots \ldots \ldots \ldots \ldots \ldots \ldots \ldots \ldots \ldots \ldots \ldots \ldots \ldots \ldots$

References $\ldots \ldots \ldots \ldots \ldots \ldots \ldots \ldots \ldots \ldots \ldots \ldots \ldots \ldots \ldots \ldots \ldots \ldots \ldots \ldots \ldots$

LABORATORY 5 - HEATING, VENTILATION, AND AIR CONOITIONING ....... 17

Discussion $\ldots \ldots \ldots \ldots \ldots \ldots \ldots \ldots \ldots \ldots \ldots \ldots \ldots \ldots \ldots \ldots \ldots \ldots \ldots \ldots$

References $\ldots \ldots \ldots \ldots \ldots \ldots \ldots \ldots \ldots \ldots \ldots \ldots \ldots \ldots \ldots \ldots \ldots \ldots \ldots \ldots \ldots$

LABORATORY 6 - FACILITY OESIGN, LOCATION, AND LAYOUT ............ 19

0iscussion $\ldots \ldots \ldots \ldots \ldots \ldots \ldots \ldots \ldots \ldots \ldots \ldots \ldots \ldots \ldots \ldots \ldots \ldots \ldots \ldots \ldots$

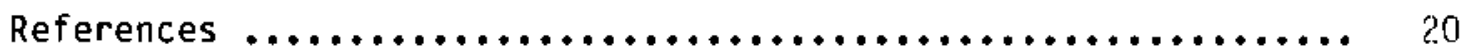

LABORATORY 7 - WASTE HEAT RECOVERY $\ldots \ldots \ldots \ldots \ldots \ldots \ldots \ldots \ldots \ldots \ldots \ldots \ldots \ldots$

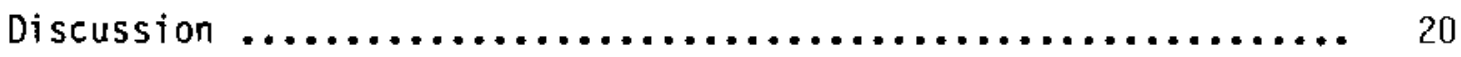

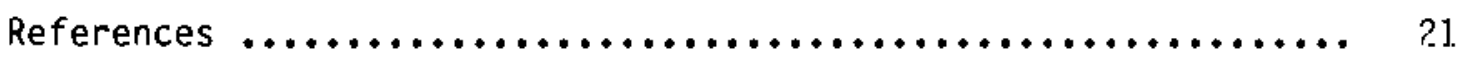

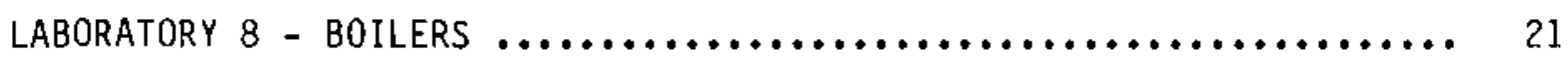

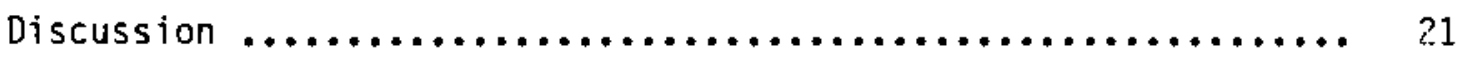

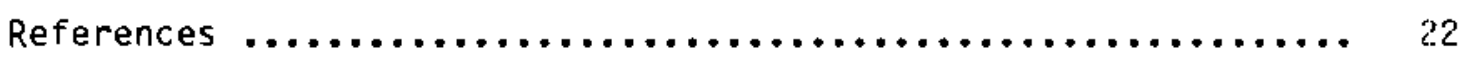

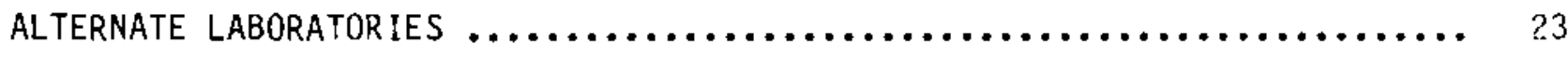

ALTERNATE LABDRATORY 1 - COST ESTIMATING ................. 23

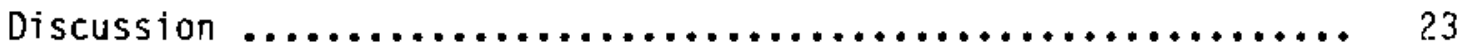

ALTERNATE LABORATORY 2 - VELOMETER EXPERIMENT .............. 24

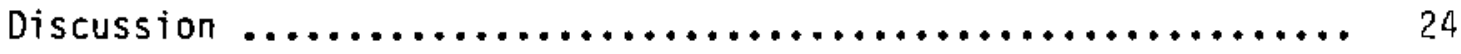

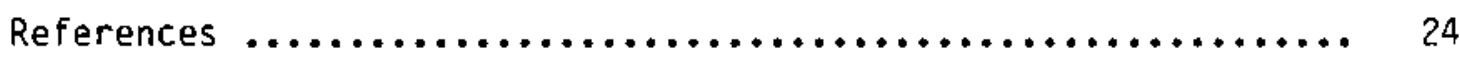


AdVANCEd Energy Management course Syllabus $\ldots \ldots \ldots \ldots \ldots \ldots \ldots \ldots \ldots \ldots \ldots, 25$

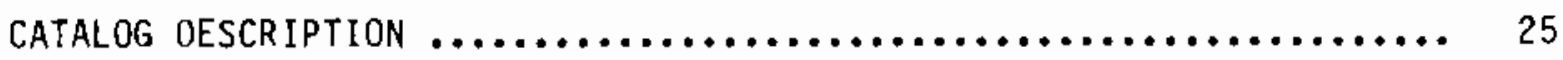

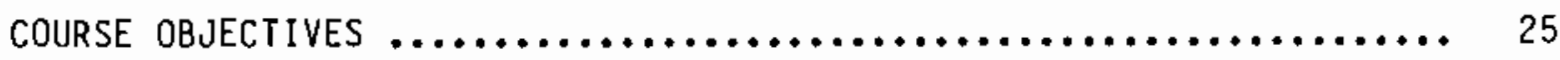

METHOD OF INSTRUCTION $\ldots \ldots \ldots \ldots \ldots \ldots \ldots \ldots \ldots \ldots \ldots \ldots \ldots \ldots \ldots \ldots, 25$

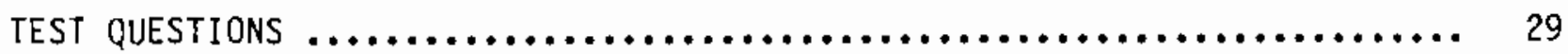

SELECTED ENERGY MANAGEMENT COURSES UNOERGRADUATE AND GRADUATE LEVEL $\ldots \ldots .61$

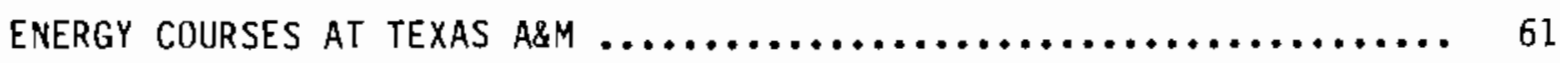

UNIVERSITY OF FLORIDA - INDUSTRIAL ENERGY MANAGEMENT COURSE $\ldots \ldots \ldots .69$

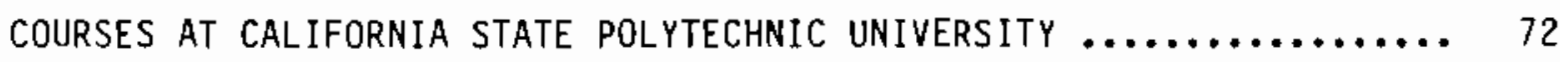

COURSES AT LOUISIANA TECHNICAL UNIVERSITY $\ldots \ldots \ldots \ldots \ldots \ldots \ldots \ldots . \ldots \ldots$

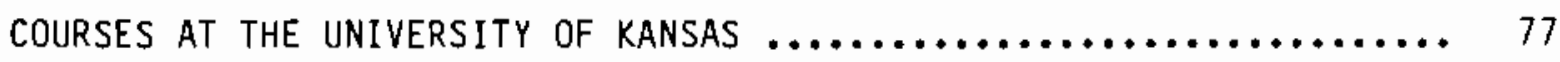

UNIVERSITY OF UTAH-INDUSTRIAL ENERGY MANAGEMENT $\ldots \ldots \ldots \ldots \ldots \ldots \ldots . \ldots$

UNIVERSITY OF CINCINNATI--ENERGY MANAGEMENT/AUDITING CURRICULUM $\ldots . .88$

CONTINUING EDUCATION COURSES $\ldots \ldots \ldots \ldots \ldots \ldots \ldots \ldots \ldots \ldots \ldots \ldots \ldots \ldots \ldots \ldots \ldots \ldots \ldots$

VIRGINIA POLYTECHNIC INSTITUTE AND STATE UNIVERSITY $\ldots \ldots \ldots \ldots \ldots \ldots . \ldots 7$

ENERGY MANAGEMENT SERIES - UNIVERSITY OF WISCONSIN $\ldots \ldots \ldots \ldots \ldots \ldots . . \ldots 9$

ENERGY MANAGEMENT/AUDITING TECHNOLOGY -

UNIVERSITY OF CINCINMATI $\ldots \ldots \ldots \ldots \ldots \ldots \ldots \ldots \ldots \ldots \ldots \ldots, 92$

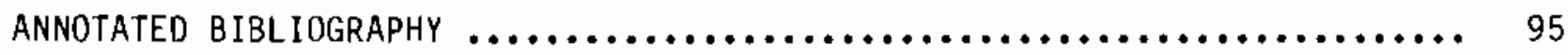

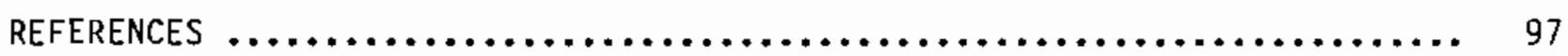




\section{TABLES}

1 Energy Management Course--Grading System $\ldots \ldots \ldots \ldots \ldots \ldots \ldots \ldots \ldots \ldots, 6 \ldots \ldots, 6 \ldots \ldots$

2 Suggested Grading Emphasis for Case Study $\ldots \ldots \ldots \ldots \ldots \ldots \ldots \ldots \ldots \ldots$

3 Suggested Grading Emphasis for Term Paper ...................... 6

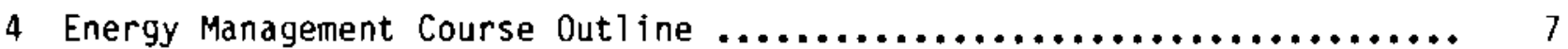

5 Advanced Energy Management Course Grading ....................... 26

6 Sample Advanced Energy Management Course Syllabus $\ldots \ldots \ldots \ldots \ldots \ldots \ldots . .27$

7 ME 436: Heating, Ventilating, and Air Conditioning--Texas A\&M ....... 62

8 ME 437: Principles of Building Energy Analysis--Texas A\&M .......... 63

9 ME 438: Energy Conservation in Industry and Commerce--Texas A\&M ..... 64

10 ME 661 : Energy Sy.stems-.Texas A\&M .......................... 65

11 ME 662: Energy Management in Industry--Texas A\&M ................ 66

12 ME 664: Energy Management in Commercial Buildings--Texas A\&M ....... 67

13 ME 665: Applications of Energy Management--Texas A\&M ............. 69

14 EIN 4321: Industrial Energy Management--University of Florida ...... 71

15 ME 306: Energy Management--California State Polytechnic University .. 72

16 Text Contents--Readings for ME 306--California State

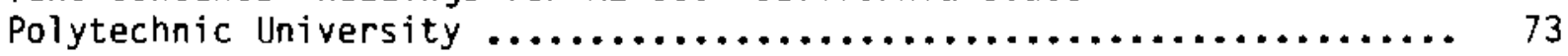

17 ME 438: Industrial Energy Conservation--Louisiana Tech ........... 76

18 ME 729: Introduction to Energy Management--University of Kansas ..... 77

19 Industrial Engineering $579--$ University of Utah $\ldots \ldots \ldots \ldots \ldots \ldots \ldots \ldots \ldots . .61$

20 Energy Management/Auditing Technology--University of Cincinnati ..... 83

21 Mechanical Energy Systems--University of Cincinnati $\ldots \ldots \ldots \ldots \ldots \ldots . .84$

22 Electrical Energy Systems--Course No. - 17-241-184--

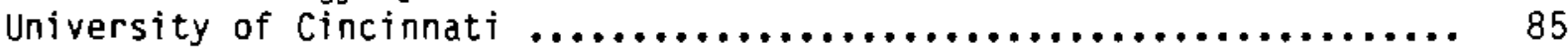


23 Energy Resource Technology--Course No. - 17-241-191

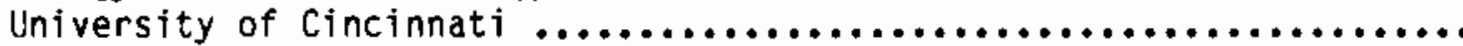

24 Energy Management Diploma Program--Virginia Polytechnic Institute and State University 
-

, 


\section{ENERGY MANAGEMENT CURRICULUM STARTER KIT}

Course syllabi were developed for two courses in energy management. The first is an undergraduate course for the junior or senior year of an engineering study plan. The second is for a graduate-level engineering course. Also presented are several laboratory exercises for the first course and sample test questions for both. Finally, sample course materials used in various engineering colleges throughout the country are presented.

\section{INTRODUCTION}

The Energy Management Curriculum Starter Kit was developed as a cooperative effort by Montana State University, Oxlahoma State University, the United States Department of Energy, and Pacific Northwest Laboratory. (a)

This kit is designed to help engineering educators develop and teach energy management courses. Educators may completely adhere to the model, or they may vary significantly from it depending upon their personal preferences. The following materials are included in this kit:

- a model curriculum for a junior-or senior-level course with accompanying laboratories - Course objectives and a list of potential textbooks are included.

- a model curriculum for a graduate-level course - This course is designed to be more flexible than the undergraduate course.

- sample test questions that can be used with the course - The test questions are drawn from material at both the undergraduate and the graduate levels.

- an annotated bibliography of potential textbooks

- course outlines from numerous universities, including the texts used in these programs, if provided

(a) Operated by Battelle Memorial Institute for the Department of Energy under Contract OE-AC06-76RLO 1830. 
- continuing education courses or adult education programs in the energy management field.

\section{DEVELOPMENT OF THIS KIT}

Two types of energy management course are found in colleges across the United States. Policy-oriented courses examine the global energy picture and a country's response. This type of course primarily concentrates on macro economics and Targe-scale systems modeling.

The second type trains the engineering student to be a good energy manager for organizations that must use energy to accomplish objectives. This energy manager can expect to deal with site-specific management and must employ engineering techniques for optimal energy use. A solid background in rate selection, fuel choice, waste heat recovery, demand leveling, employee motivation, and a host of other techniques is required. The courses described in this kit were designed to fill this need.

\section{USING THE MODEL COURSES}

Users of this starter kit will probably examine the Model Energy Management and Advanced Energy Management Course syllabi, then obtain copies of the potential texts. Once a primary text for the class has been chosen, instructors may use the other potential texts and listed references to strengthen specific weaknesses in their chosen text.

The course outlines shown here may be used as references for suggestions. The sequence is quite flexible and may be easily modified. Several laboratories are suggested to help the budding energy manager become familiar with the assorted equipment at his disposal and to gain firsthand experience in the occurrence of various phenomena, e.g., power factor.

Test questions from a variety of areas are listed. Questions are drawn from both the undergraduate and the graduate levet. 
OTHER COURSE CURRICULA

Numerous colleges and universities have shared their energy course curricula. By studying courses available in a variety of areas, engineering educators may develop a more complete program. Both undergraduate- and graduate-level courses are represented. Prerequisites are shown if they were provided by participating universities.

CONTINUING EDUCATION PROGRAMS

Several colleges have recognized the necessity for continuing education in the field of energy management. These adult programs are designed for 1) the licensed professional wanting to expand his knowledge and 2) the high school graduate training for entry-level positions in firms requiring a knowledge of the energy field. Both types of programs are represented in this kit. 


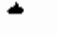

.

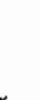

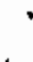




\section{MODEL ENERGY MANAGEMENT COURSE}

The following outline is a possible design for a junior-to senior-level course requiring a good engineering science basis. Forty-five class periods are dedicated to the course with a laboratory exercise approximately every fourth period. If no laboratory is used or if only a few sessions are used, the material can be expanded to cover more areas or more depth in each subject. Catalog Description

Energy Management is a study of the objectives, design, implementation, and supervision of energy management programs. The scope includes energy conservation, choice of energy sources, safety and security of fuel storage, and contingency planning with emphasis on improving profits (reducing costs) through optimal energy management. Outside speakers and field trips may be utilized. Students must have completed the following prerequisites: engineering calculus, heat transfer, and engineering economy.

Objectives

At the conclusion of the course, the student should:

- understand the basic energy situation and present and future problems

- understand the profit improvement (cost reduction) potential of energy management

- possess the necessary talents to design, implement, operate, and manage successful energy management programs.

Method of Instruction

The course is presented primarily in a lecture format with some laboratory exposure. Field trips may be utilized. Several texts are recommended, but the choice of a primary text is the instructor's prerogative. Table 1 gives one possible grading system for the course.

The Case Study is an energy management study for an industry, office building, store, church or other building or an in-depth probe into an appropriate subject. The subject must be approved. 
TABLE 1. Energy Management Course--Grading System

\begin{tabular}{ll} 
Two Tests $0 \%$ each & $40 \%$ \\
Final Exam & $25 \%$ \\
Case Study or Research Paper & $20 \%$ \\
Homework and Special Assignments & $15 \%$ \\
\hline
\end{tabular}

The Case Study should be a complete analysis (audit of the energy profile with economic analysis and specific proposals for profit improvement). Students will work in teams of two. Table 2 suggests a point system to be used in evaluating the case study.

TABLE 2. Suggested Grading Emphasis for Case Study

\begin{tabular}{ll}
\multicolumn{1}{c}{ Grading Categories } & \\
\hline Relations With Company & $15 \mathrm{pts}$. \\
Depth and Quality & $45 \mathrm{pts}$. \\
Report Structure & $20 \mathrm{pts}$. \\
Grammar, Spelling & $20 \mathrm{pts}$. \\
\cline { 2 - 2 } & $100 \mathrm{pts}$.
\end{tabular}

Research papers must be approved before submission. The student should thoroughly examine a topic that pushes the frontiers of knowledge concerning that subject. Students might examine cogeneration potential for small industries, or they could look at industrial uses of solar energy. Table 3 shows the point system suggested for the research paper.

TABLE 3. Suggested Grading Emphasis for Term Paper

\begin{tabular}{|c|c|}
\hline Grading Categories & Points \\
\hline $\begin{array}{l}\text { Choice of Subject } \\
\text { Originality } \\
\text { Depth and Quality } \\
\text { References } \\
\text { Report Structure } \\
\text { Grammar, Spelling }\end{array}$ & $\begin{array}{l}10 \\
10 \\
40 \\
10 \\
15 \\
15 \\
\end{array}$ \\
\hline Total & 100 \\
\hline
\end{tabular}


A complete outline of the undergraduate energy management course appears in Table 4. Laboratories are recommended at intervals throughout the course. A key to references is shown at the bottom of the table.

\section{TABLE 4. Energy Management Course Outline}

\begin{tabular}{|c|c|}
\hline Perlod & Topic \\
\hline 1 & Introduction To Course, Overvlew of Materlal \\
\hline 2 & $\begin{array}{l}\text { Today's Energy Stituation - the global and } \\
\text { natlonal energy pleture and predictions for the } \\
\text { future }\end{array}$ \\
\hline 3 to 4 & $\begin{array}{l}\text { Inltiating, Organizing, and Managing Energy (EM) } \\
\text { Management Programs. How to design on EM } \\
\text { organization and start it properly. How to } \\
\text { monitar it. }\end{array}$ \\
\hline 4 to 5 & $\begin{array}{l}\text { Energy Auditing - The role of the energy } \\
\text { auditor. Specific arees of concern ond } \\
\text { necessary equipment. Audlting checklists. }\end{array}$ \\
\hline 6 & $\begin{array}{l}\text { Utflity Bills - How energy is bllled. How to } \\
\text { read rate schedules. Calculating and checklng } \\
\text { blilis. }\end{array}$ \\
\hline 7 & Laboratory 1 - Auditing, Utility Rate Schedules \\
\hline $8,9,10$ & $\begin{array}{l}\text { Lighting - How to measure ilght levels. } \\
\text { Advantages and disadvantages of different ilght } \\
\text { sources. Energy efficfency. Design of ilight } \\
\text { systems. }\end{array}$ \\
\hline 11 & Labor atory 2 - Lighting Systems \\
\hline $12,13,14$ & $\begin{array}{l}\text { Insulation - The importance of insulation. } \\
\text { Calculation of heat loss and gain. } \\
\text { Economles of heat loss and gain. } \\
\text { Types of insulation. }\end{array}$ \\
\hline 15 & Laboratory 3 - Insulation Laboratory \\
\hline $16,17,18$ & $\begin{array}{l}\text { Electrfcal Energy Management - Reducing energy } \\
\text { costs. Energy management control systems, } \\
\text { motors, and power factor improvements, etc. }\end{array}$ \\
\hline 20 & Laboratory 4 - Electricity \\
\hline $19,20,21$ & $\begin{array}{l}\text { Heating, Ventllation, and Alr Conditioning - } \\
\text { Brlef introduction to the different types of } \\
\text { HYAC equipment. Economlics, economizers, night } \\
\text { setback, and duty cycling }\end{array}$ \\
\hline 22 & Laboratory 5 - HVAC - Velometer, Economizer \\
\hline $23,24,25$ & $\begin{array}{l}\text { Bullalng Envelope - What can be done in the } \\
\text { envelope Itself? Bullding Insulatlon, energr- } \\
\text { efflelent glass, passive solar plannling, } \\
\text { Inflitratlon, new faclitity design. }\end{array}$ \\
\hline
\end{tabular}

Ref. $\rightarrow$ Page

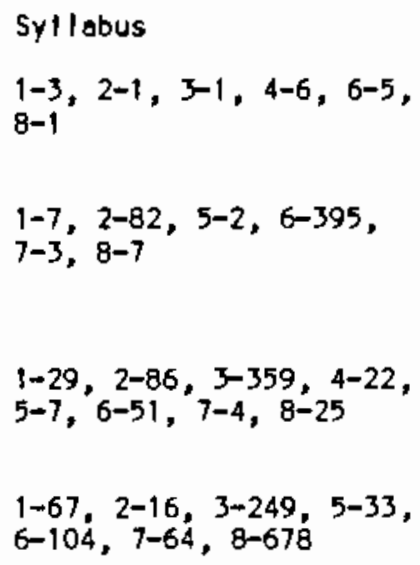

See Laboratorles Section

$1-90,2-172,3-212$, 5-172, 6-91, 7-82, $8-399,9-100$

See Laboratorles Section

$1-204,2-362,3-90$, $5-83,6-392,7-192$, $8-459$

See Laboratorles Section

$1-141,2-269,3-250$,

$5-170,6-80,7-89$,

$8-322,9-3$

See Laboratorles Section

$1-109,2-352,3-166$, 5-128, 6-237, 8-303, 9-83

See Laboratory Section

$3-85,5-129,6-218$, $8-269$ 
TABLE 4. (contd)

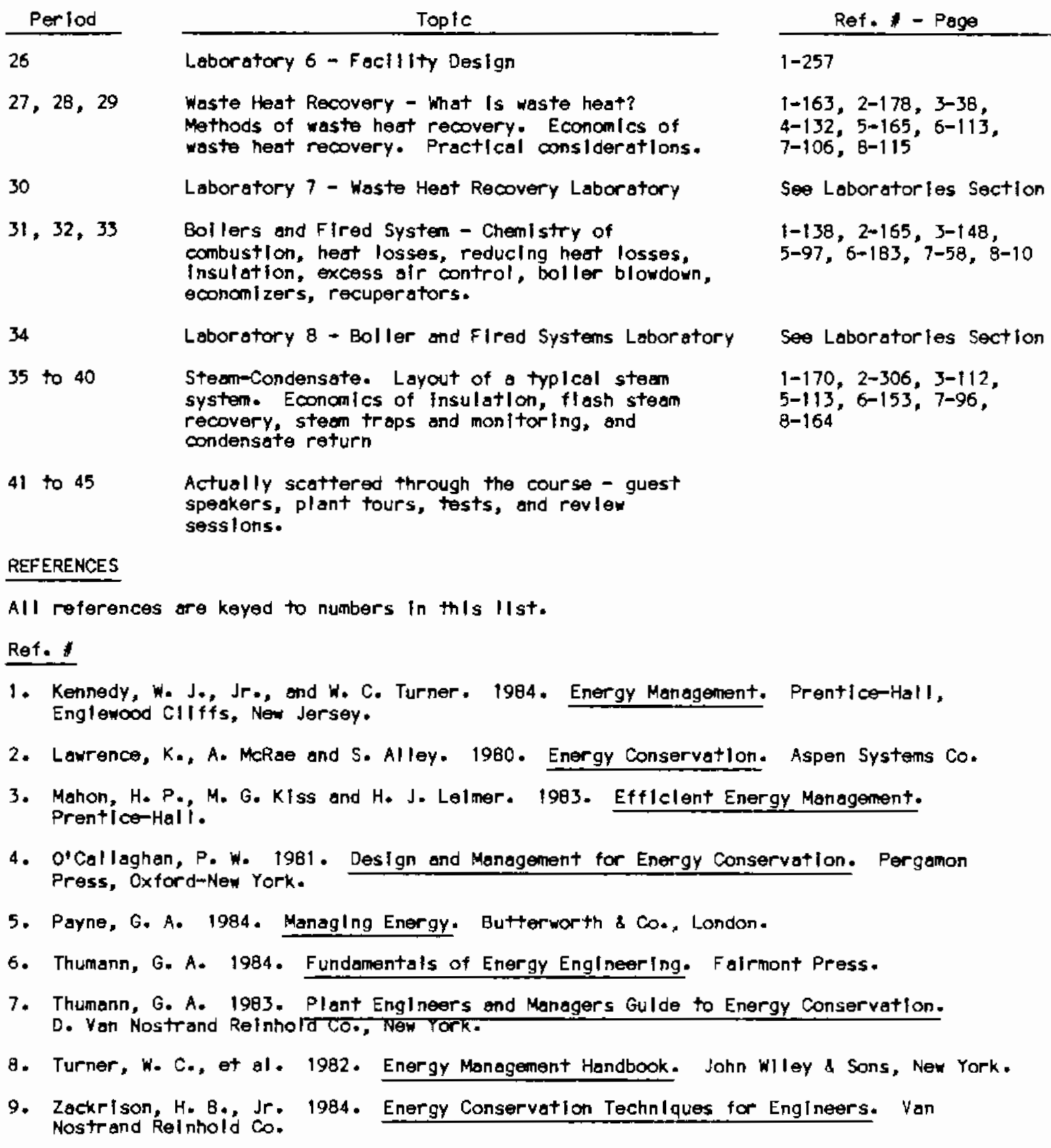




\section{ENERGY MANAGEMENT LABORATORIES}

The laboratories described in this section provide students the opportunity to gain firsthand experience with both the equipment at their disposal and the various techniques used by energy managers. These laboratories were written to accompany the undergraduate energy management course.

\section{LABORATORY 1}

Three Iaboratories are presented in this section that may be used individually or combined.

\section{Energy Auditing}

The objective of this laboratory is to instruct students in the "art" of energy auditing and methods used in conducting an audit. A sample energy audit report and energy audit equipment are needed for this laboratory. The reasons for conducting audits, step-by-step procedures, auditing techniques, sample reports, and typical auditing equipment are covered in this laboratory.

Discussion

The instructor will probably wish to use a format similar to the outline given below.

1. Discuss the reasons for conducting an energy audit. The rationate might include:

- accounting for all energy users within a plant

- gaining knowledge about plant processes

- locating possible savings opportunities.

2. Discuss example standard operating procedures for conducting an energy audit. One example might be as follows:

- meet with plant personnel

- conduct a brief tour of plant

- hold a short meeting to discuss initial observations

- take measurements needed (e.g., temperature, light levels)

- plan another short team meeting 
- Discuss findings with plant personnel

- prepare a formal report during the next few weeks.

3. Discuss auditing techniques. The auditing techniques emphasized in this laboratory might include a physical inspection of the plant and personnel interviews. During the physical inspection, the energy auditor would "touch, listen and look" and take instrument

readings. When giving personnet interviews, the energy auditor might

- speak with maintenance crews

- speak with technicians

- speak with management personnel

- watch for consistent answers from the various groups. Perhaps management and maintenance disagree on how long the lights are on daily.

4. Discuss example report formats and show a sample report. The format might include the following sections, for example:

- a description of plant

- the main energy users

- an outline of energy saving opportunities

- the calculations for each saving opportunity

- a summary of total savings opportunities.

Show typical auditing equipment and discuss each. Examples might include digital thermometers, velometers, tape measures, or flash lights.

\section{References (See Reference List)}

Kennedy and Turner 1984, P. 29

Lawrence, McRae and A1ley 1980, p. 86

Mahon, Kiss and Leimer 1983, pp. 60, 65, 359

0'Callaghan 1981, pp. 22, 117, 211

Payne $1984, \mathrm{pp} .7$ to 16 
Thumann 1983, p. 4

Thumann 1984, p. 51

Turner et a1. 1982, pp. 24 to 71 .

An audit tape has been developed by The American Consulting Engineering Council. This tape is highly recommended for a laboratory-type "audit." Contact:

Mr. Alex Willman

ACEC Research

101515 St. N.W.

Suite 802

Washington, DC 20005.

\section{Electric Rate Schedules}

The objective of this laboratory is to familiarize students with the complexities of utility rate structures in their home state and in other states. The materials necessary for this laboratory are rate schedules and sample electric profiles.

Discussion

The instructor should cover the material listed below.

1. Discuss the purpose of various rate schedules. The discussion should focus on the necessity for various types.

2. Discuss the following types of rate schedules:

a. residential

b. commercial

c. industrial

d. experimental (standby, buy back, interruptable).

3. Discuss kilowatt-hour (kWh) and its measurement.

4. Discuss how utilities charge for khh. Discuss declining rates based on usage.

5. Discuss how and why utilities bill for peak demand. Ratchet clauses, actual demand and billed demand should be covered. 
6. Discuss power factor and how it is measured. Discuss how and why utilities bill for power factor.

7. Discuss the fuel adjustment factor.

8. Show students examples of how a total bill would be calculated for the same business on various rate schedules.

9. Give students hypothetical electric usage profiles and have them calculate the total bill based on different rate schedules. Have them compare the total costs for the different rate schedules.

\section{References}

Kennedy and Turner 1984, p. 67

Lawrence, McRae and Alley, P. 16

Mahon, Kiss, and Leimer 1983, p. 249

Payne 1984, P. 33

Thumann 1983, p. 64

Thumann 1984, p. 104

Turner $1982, \mathrm{P} .678$.

\section{Water and Natural Gas Rate Schedules}

The objective of this laboratory is to familiarize students with the methods utilities use to bill residential, commercial, and industrial water and natural gas customers. Students will work with actual water and natural gas consumptions.

\section{Discussion}

The discussion will center on measuring consumption and the calculation of costs for both natural gas and water.

Natural Gas

1. Discuss units of measurement for natural gas consumption - this is usually determined in thousands of cubic feet (mcf).

2. Discuss the cost of natural gas. 
Water

1. Discuss the units of measurement for water consumption - this is usually determined in thousands of gallons.

2. Discuss the cost of water.

3. Discuss sewer costs and how they are calculated by the utilities. Sometimes sewer costs are based on water consumption. Discuss how excessive bills can result if much of the water consumed is not returned through the sewer but stays with the product or is evaporated.

Activity

Give students actual consumptions and have them calculate actual bills. Include taxes and other costs. References (See Reference List)

Kennedy and Turner 1984, p. 67

Lawrence, McRae and Alley 1980, p. 16

Mahon, Kiss and Leimer 1983, p. 249

Payne 1984, P. 33

Thumann 1983, P. 64

Thumann 1984, p. 104

Turner 1982, p. 678.

\section{LABORATORY 2 - LIGHTING}

This laboratory would appropriately follow lectures dealing with such topics as measurement of light sources, advantages of different types of sources, and energy-efficient lighting systems. The objective of this laboratory is to give students firsthand experience in recognizing various lighting types and characteristics. The equipment needed for this laboratory includes a variety of light sources, color charts, and power consumption charts. 


\section{Discussion}

1. Show examples of various light sources. High pressure sodium (HPS) and mercury vapor are good examples.

2. Discuss the applications of the various types of lights. Discuss light quality, energy consumption and color determination.

3. Darken the room and turn on one of the light types. Point out the color characteristics and luminosity.

4. Discuss the economics of converting from one light source to another more efficient light source. Areas to be covered here might include power savings, fixture costs, bulb costs and bulb life.

5. Discuss the basics in lighting design, e.g., coverage area, lumen rating, mounting and height.

6. Have the students locate a specific lighting system on campus and suggest a more practical and efficient light source.

References (See Reference List)

Kennedy and Turner 1984, pp. 90 to 109

Lawrence, McRae and Alley 1980, pp. 172, 343, 351

Mahon, Kiss and Leimer 1983, pp. 212 to 249

Payne 1984, pp. 172 to 178

Thumann 1983, P. 82

Thumann 1984, p. 91

Turner et al. 1982, pp. 399 to 417

Zackrison 1984, pp. 100 to 267.

\section{LABORATORY 3 - INSULATION}

The objective of this laboratory is to familiarize students with various types of insulation and to discuss their applications. The laboratory also provides an opportunity for students to review basic heat flow equations and their applications to insulation. The only materials needed to present this laboratory are various samples of insulation material. 
Discussion

1. Review basic heat flow equations. Cover surface resistance and insulation resistance. Discuss the units involved with the thermal resistance and conductance. Discuss equivalent thickness for pipe insulation.

2. Show example equations involving various composite cross sections. Give examples of different materials, thicknesses and temperatures. Show pipe insulation examples.

3. Discuss the various types of insulations, their properties and applications.

4. Give students example problems with various goals in mind. An example is listed here.

Given the inside and outside temperatures and a stainless steel surface with no insulations, calculate heat loss per hour.

Given the surface temperature and the ambient temperature, select an insulation type and thickness to give a desired surface temperature. (Personnel Protection)

5. Discuss the law of diminishing returns as it applies to the thickness of insulation applied. Give students an opportunity to explore the economic aspects of insulation.

\section{References}

Kennedy and Turner 1985, p. 204

Lawrence, McRae and Alley, p. 362

Mahon, Kiss and Leimer 1983, P. 90

Payne 1984, P. 83

Thumann 1983, P. 192

Thumann 1984, p. 392

Turner et al. 1982, p. 459. 


\section{LABORATORY 4 - ELECTRICAL ENERGY MANAGEMENT}

During this laboratory, students will have an opportunity to explore wise energy management in a specific building or plant. Students will become familiar with the equipment used to measure electrical quantities. Peak times are also discussed.

The objective of this laboratory is to introduce students to the basics of electrical energy management. A volt meter, amp meter, watt meter, demand meter, and a kilowatt-hour meter are needed for this laboratory. To obtain this equipment, contact the electrical engineering department of a college or a local electric utility.

Discussion

1. Introduce basic electrical terminology: volts, amps, watts, volt-amps, volt-amps-reactive (VAR), power factor $(p f)$, capacitance, inductance, alternating current, peak demand, kilowatt-hours

2. Show students examples of the various instruments used to measure electrical quantities. Volt meters, amp meters, watt meters, VAR meters, and demand meters are suggested.

3. Demonstrate how the various instruments work. A test may be set up, or the students might visit an electrical engineering laboratory.

4. Show the class examples of a plant's demand profiles. Discuss the types of loads that make up the daily peaks or the seasonal peaks. Discuss the impact of ratchet clauses and how ratchet penalties can be reduced.

5. Show how the daily demand can be cut, and discuss how the plant's load profile would change. Show students how rescheduling operations, reducing lighting demands during peak hours, and duty cycle air handling units may be useful in decreasing the daily demand. "Before and after" load profiles might be used for illustration. 
6. Discuss the importance of reducing demand during the "peak times." A question for students to consider is given below.

Question: Will reducing the bulb wattage in existing light fixtures reduce the peak demand?

Answer: Only if the lights are on during the time of peak demand.

7. Have students work various electrical problems. A sample problem is listed here.

- Calculate the annual cost of running a motor.

- Calculate the kVAR needed to correct the power factor.

\section{References}

Kennedy and Turner 1984, p. 41

Mahon, Kiss and Leimer 1983, p. 250

Payne 1984, pp. 170-183

Thumann 1984 , p. 80

Turner et al. 1982, pp. 322 to 355,659 to 672

Zackrison 1984, pp. 1 to $40,73,268$

\section{LABORATORY 5 - HEATING, YENTILATION, AND AIR CONDITIONING}

Students will focus on the various methods for improving the heating/ cooling loads on a given building.

The major objective of this laboratory is to discuss the costs associated with heating, ventilating, and air conditioning buildings. A velometer, a thermometer, and diagrams of HVAC configurations will be needed in the presentation of this workshop.

Discussion

1. Show examples of heating and air conditioning load profiles for a year. Include both electric and natural gas heating.

2. Discuss methods of calculating the heat load of a building. Compare degree day, bin data, and other methods. 
3. Discuss the various building types and how internal heat affects the amount of heating and air conditioning needed. Examples of internal heat might include lighting, human body heat, the heat generated by compressors, and the heat generated by machines.

4. Discuss how outside temperatures affect building heating and air conditioning. It is important for students to understand that some buildings must be air conditioned even when it is freezing outside.

5. Discuss the effects of solar heating on building heating and air conditioning.

6. Discuss building envelopes and why a poor building envelope will cause losses.

7. Discuss methods of reducing building heating and air conditioning costs. Instructors will probably want to include night setback and the use of timers, economizers, and enthalpy controls.

8. Show pictures of various types of HVAC configurations; these are extremely important. Discuss the strengths and weaknesses of each. Discuss economizers.

9. Teach students how to use velometer readings to calculate infiltration losses.

10. Have the students divide into groups. Each group will prepare a mini-report with suggestions for improving the heating/cooling load on a given building.

\section{References}

Kennedy and Turner 1984, pp. 109 to 125

Lawrence, McRae and Alley 1980, pp. 353 to 355

Mahon, Kiss and Leimer 1983, pp. 36 to 59, 126 to 211

D'Callaghan 1981, pp. 128 to 130

Payne 1984, pp. 237 to 239

Turner et al. 1982, pp. 303 to 321

Zackrison 1984, pp. 9, 73 to 78 . 


\section{LABORATORY 6 - FACILITY DESIGN, LOCATION, AND LAYOUT}

This Taboratory was designed primarily to foster a greater understanding of the manner in which building locations and design affect energy management.

The objective of this laboratory is to familiarize students with the importance of facility design, location, and layout in energy management. To present this laboratory, you will need pictures or slides of well-designed buildings.

\section{Discussion}

1. Discuss the elements that should be considered in the location of a plant. The following items might be considered:

Is the plant near transportation facilities?

Is the plant located away from windy areas?

Are natural windbreaks and sun screens located nearby?

Is there an abundant supply of natural resources, e.g., water or fuel?

2. Discuss the design of the facility. Numerous items will impact the building design. Among these are the following areas:

- sun load

- air infiltration

- outside vegetation or lack of it

- overhangs

- parking.

In this discussion, it might be wise to also show students why it is more effective to design than to retrofit after construction. The instructor should also cover the following areas:

- the location of windows, doors, and insulations

- HVAC, air compressors, waste heat recovery

- material handling and warehousing concerns.

Have students design a specific type of building using energy-efficient construction considerations. Have each student explain the design. 


\section{References}

"Facilities Planning and Design for Energy, Water, and Hazardous Waste Management," Proceedings AIIE Annual Conference, Dallas, Texas, May 1986

Kennedy and Turner 1984, p. 256

Lawrence, McRae and Alley, p. 127.

\section{LABORATORY 7 - WASTE HEAT RECOVERY}

This laboratory focuses on the generation of waste heat and ways that the energy manager can utilize waste heat recovery. The laboratory also covers some of the problems encountered in waste heat recovery.

The primary objective of this laboratory is to discuss various methods used in waste heat recovery. Students should become aware that energy and money can be saved through this utilization.

Discussion

1. Show examples of the various types of heat exchangers, and discuss their use. Examples might include gas-to-liquid exchange or air-toair exchangers.

2. Discuss specific instances where waste heat might be recovered and how the heat could be used.

3. Discuss the equations involved with calculating the recoverable heat and the size of the heat exchanger.

4. Discuss the recovery of exhaust heat to utilize as process heat.

5. Discuss the economics of heat recovery.

6. Discuss the problems encountered in waste heat recovery. One example is the condensation of stack gases.

7. Describe a hypothetical plant. Have students give suggestions for waste heat recovery. 


\section{References}

Kennedy and Turner 1984, p. 163

Lawrence, McRae and Alley 1980, p. 178

Mahon, Kiss and Leimer 1983, p. 38

0 'Catlaghan 1981, p. 132

Payne 1984, P. 165

Thumann 1983, p. 106

Thumann 1984 , p. 113

Turner et al. 1982, p. 115.

\section{LABORATORY 8 - BOILERS}

This laboratory will allow an in-depth discussion of the various types of boilers and their efficient operation. The laboratory is most effective if students can tour a local physical plant for practical experience in this area. The primary objective is to cover the energy-saving opportunities concerned with boilers.

Discussion

1. Oiscuss the various types of boilers, e.g., fire in tube, water in tube. Show pictures. Take a short tour so that students can see boilers in operation.

2. Discuss various types of fuel used. Coal, natural gas, and fuel oit are common examples.

3. Discuss single-pass and multiple-pass boilers.

4. Discuss economizers and recuperators and their applications.

5. Discuss boiler efficiency and factors that affect boiler efficiency such as feedwater solids.

6. Discuss how excess air affects stack heat losses.

7. Discuss flue gas analysis. Show the equipment used and the equations that apply.

8. Discuss savings in minimizing excess air level. 
9. Show examples of various boiler types, fuel types, fuel costs, operating hours, and efficiencies.

10. Give students hypothetical problems to work.

11. If possible, tour a local plant, perhaps the university physical plant. Have the students take excess air readings, look for uninsulated 1 ines and tanks, and check for economizers/recuperators.

\section{$\underline{\text { References }}$}

Kennedy and Turner 1984, p. 138

Lawrence, McRae and Alley 1980, p. 165

Mahon, Kiss and Leimer 1983, p. 148

Payne 1984, p. 97

Thumann 1983, p. 58

Thumann 1984, p. 183

Turner et al., p. 10. 


\section{ALTERNATE LABORATORIES}

The two laboratories given in this section may be used as alternates or may be incorporated within other laboratories.

\section{ALTERNATE LABORATORY 1 - COST ESTIMATING}

The basic considerations in estimating the costs of implementing energy saving ideas are dealt with in this laboratory. Discussion

1. Discuss the steps of cost estimating procedures. A sample procedure is listed below:

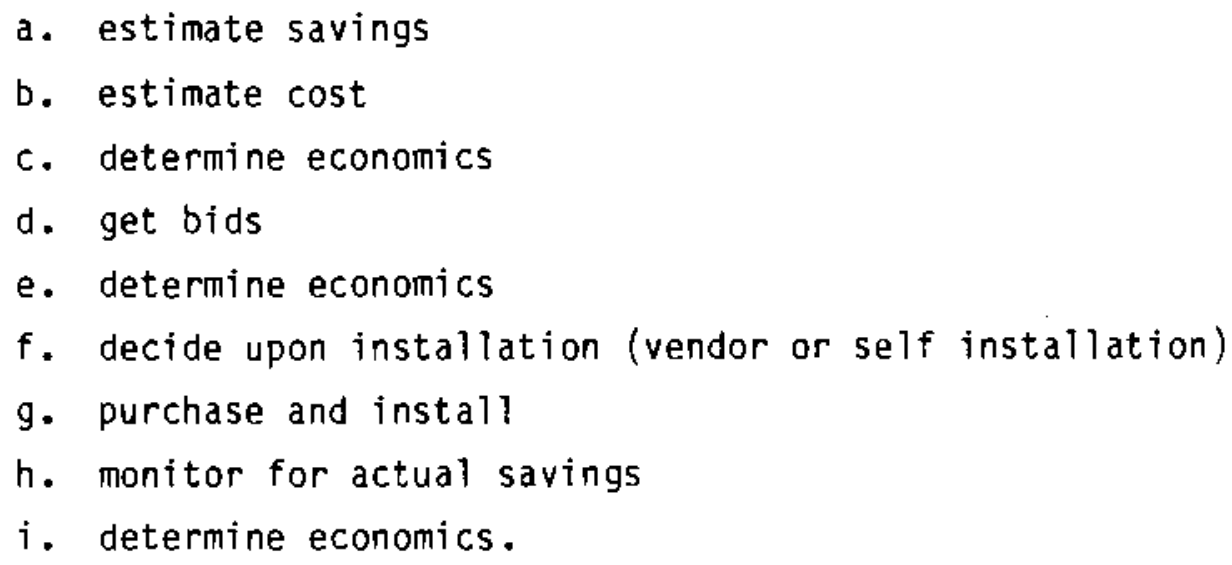

2. Explain cost factors. In this discussion, the instructor will probably wish to cover equipment, installation, maintenance, training, and other recurring costs.

3. Discuss various cost estimating sources. Three recommended sources are the Means Cost Data Book, vendor price lists, and the McMaster Catalog.

4. Give the students an example system and have them get estimates. Compare the range of estimates and considerations that the students give. 


\section{ALTERNATE LABORATORY 2 - VELOMETER EXPERIMENT}

This laboratory introduces the velometer as an energy-management tool. The basic equations used with the velometer are reviewed. A velometer and bindata charts are required for the presentation.

Discussion

1. Discuss infiltration, e.g., losses through cracks, under doors, and through vents.

2. Discuss ventilation requirements and health regulations.

3. Discuss the operation of the velometer. Cover six-, eight-, and tenpoint measurement schemes. Ask the students why these are necessary.

4. Discuss mass flow rate calculations and heat loss calculations based on flow rate.

5. Break the class into groups, and have them measure an infiltration source. Have the students calculate the losses due to heating and air conditioning. Students will need bin-data weather information or degree-day information.

References

Turner et al. 1982 , p. 451. 


\section{ADVANCED ENERGY MANAGEMENT COURSE SYLLABUS}

The following outline is a possible design for a graduate-level course in the field of energy management. The students should have completed the first energy management course and should have a good basic understanding of the principles involved. No laboratories are used. The sequence is designed to be more flexible than in the model undergraduate course. Outside references and recent articles are much more important in this course.

\section{CATALOG DESCRIPTION}

This course is an advanced study of the design, the implementation, and supervision of energy management programs. The course will concentrate on areas more technologically or managerially complex than the basic energy management course. The course covers such topics as cogeneration, alternative energy, energy reporting, and energy management control systems.

\section{COURSE OBJECTIVES}

The student should become more adept in increasingly sophisticated areas of energy management. The course will enable the student to become a better manager by examining accounting and reporting measures and cost-center metering. The student will be able to learn more about technologically sophisticated areas of energy management.

METHOD OF INSTRUCTION

The course witl be primarily presented in a lecture format. The instructor will choose an appropriate text. Several additional sources are shown in the reference section. Laboratory and field trips should be incorporated. Outside lecturers may be used where appropriate. Table 5 shows one possible scenario for grading this course.

Test questions have been developed that may be suitable for this course. Refer to the Test Questions section for ideas. 
TABLE 5. Advanced Energy Management Course Grading

Two tests $40 \%$

Research paper 20\%

Homework, special assignments $\quad 15 \%$

Final exam $\underline{25 \%}$

TOTAL $100 \%$

One important aspect of this course is the research paper. This paper should be an in-depth analysis of an energy management subject. For example, students could analyze the advantages, disadvantages, and pitfalls of an energy management control system. A paper could present a design and an economic analysis of a solar preheating system for an industrial process. The paper should be of research caliber and worthy of publication in an energy journal.

One possible course syllabus for the Advanced Energy Management Course is presented in Table 6. Reference sources have been keyed and are listed at the bottom of the table. Additional reference sources are listed where applicable. 
TABLE 6. Sample Advanced Energy Management Course Syllabus

$\frac{\text { Perfod }}{1}$

2 to 12

$\frac{\text { Tople }}{\text { Introduction to course }}$

Energy management control systems What is an ENCS? What different types are avallable? (Programable, controllers, mainframes, micros). Control Schemes (Duty Cycle, Demend Shed and Optimum Start-Stop).
Reference Number and Page

$1-177,2-76,3-171,5-77$ $6-105,7-89,8-356,9-139$

Other References

OHavlano, VIctor B., Energy Management (USA: OTS Publlcatlon 1983).

Owens, George R. March 1983. "EMS Parts 1 and 2," Energy Management.

"Reader Survey and Rating," Energy User Nows, New York.

"Direct DIgltal Control," TechnIcal Brief 16. Energy Extension Servlco of Georgla Tech., Atlanta, Gorgla.

"Computer Based Energy Managenent," Technlcal Brlef 33, Energy Extension Servlo of Georgla Tech., Atlanta, Georgla.

13 to 22 Cogeneration - What is ogeneration?

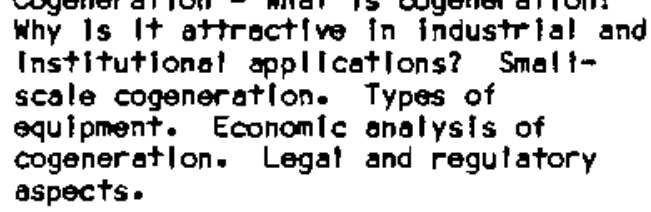

Other References

Pollmeros, George. 1981. Energy Cogenerotion Handbook. Industrial Press, Inc.

The Regulatory Polley Institute, The Industrlal Cogeneration Manual,

Washington, D.C.

Kibert, Charles J., and W. A. Smlth. 1982/Jan. 1983. "Analysis of Pressure Reducing Statlons for Cogeneration," Energy Englneering, p. 5.

23 to 30

$$
\begin{aligned}
& \text { Alternative Energy Appl I cetlons. What } \\
& \text { is on alternative energy source? } \\
& \text { Advontages and disadvantages of each. } \\
& \text { Economlcs of al ternative energy } \\
& \text { sources. Solar-, Ind-, refuse-derived } \\
& \text { fuels. Future of at ternative energy. }
\end{aligned}
$$

30 to 34

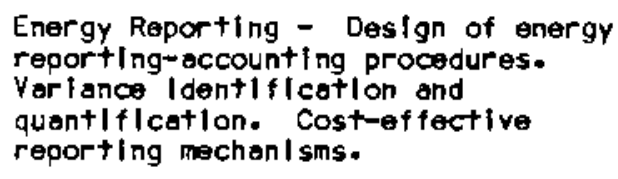

Other References

Turner, W. C. June 1984. "Energy Accountlng: A Now Fleld Results," Ile Transectlons, poge 135.

Shirley, James M. 1985. Multiple Locotlon Energy Accounting Systems: A Case Study," 1985 Annual International industrlal Engl neerling Conference Proceedings. Chi cogo. 
35 to 37 Experimental Rate Schedules - Unlque rate schedules offered to Industrites. interruptable, curtallable and standby schedules: What con they offer companies? identifyling potentlal appllcatlons. Varfous utility schedules avallable from the local utllity or rate commission. (Concentrate on the ner experimental ones, not the conventional ones.)

37 to 41

Miscellaneous toples not covered else-

where. Malntenance for energy management, fleet menagement, other consideratlons.

42 to 45 Actually scattered through course guest speakers, tests, plant tours, review sesslons.

References

1 - Kennedy and Turner 1984

2 - Lawrence, MCRae and Alley 1980

3 - Mahon, KIss and Lelmer 1983

4 - O'Caliaghen 1981

5 - Payne 1984

6 - Thumann 1984

7 - Thumann 1983

8 - Turner et ol. 1982

9 - Zackrison 1984 


\section{TEST QUESTIONS}

Sample test questions that instructors might be able to use are listed in this section. Major categories have been identified. The solutions are not provided for obvious reasons. These can be obtained by contacting

Dr. Wayne $C$. Turner

Industrial Engineering and Management

Oklahoma State University

St $\dagger 1$ iwater, Ok lahoma 74078

Work (405) 624-6055

Some questions are more appropriate for an undergraduate course. Others may be most suitable for graduate level courses.

\section{Electric Rate Schedule}

1. You work for Ajax, a manufacturer of adjustable wrenches. You are trying to understand the billing procedure and encounter the following. Calculate the bill for the month of November. Ignore any charges other than those 1 isted.

Rate Schedule

$\$ 5.00$ per $\mathrm{kW}$ of billed demand

$\$ 0.03$ per kWh of electric consumption

Allowed kilovar (kvar) (with no charge) $=70 \%$ billed demand

Excess kvars billed at $\$ 0.75$ per kvar

Demand ratcheted $80 \%$ over last 12 months

Sales $\operatorname{tax}=3 \%$.

Month of November

Actual demand $=1000 \mathrm{~kW}$

Actual kvar $=790 \mathrm{kvar}$

Actual consumption $=300,000 \mathrm{kWh}$.

Previous Demand

Oec. $1000 \mathrm{~kW}$; Jan. $900 \mathrm{~kW}$; Feb. $950 \mathrm{~kW}$; March $960 \mathrm{~kW}$; April

$960 \mathrm{~kW}$; May $1100 \mathrm{~kW}$; June $1150 \mathrm{~kW}$; July $1350 \mathrm{~kW}$; Aug. $1150 \mathrm{~kW}$;

Sept. $1100 \mathrm{~kW}$; 0ct. $900 \mathrm{~kW}$. 
Power Factor

2. For the rate schedule in Problem 1, what is the base power factor (pf) (i.e., the pf below which a penalty is charged)?

Heat Loss and Insulation

3. At Ajax, you encounter a large indoor tank (see sketch) that is full of hot oil at $110^{\circ} \mathrm{F}$. The tank is heated by steam coils. The boiler supplying the steam is $78 \%$ efficient and burns natural gas at $\$ 5.00$ per million Btu. Ambient air is at $70^{\circ} \mathrm{F}$ year round. The tank is used 8760 hours per year. Calculate:

10 pts. A. The total heat loss with no insulation

10 pts. B. The total heat loss with 1 inch of fiberglass blanket insulation covered with an aluminum jacket.

10 pts $c$. The savings in Btu and dollars from installing the insulation.

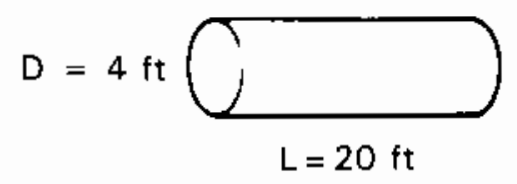

Lighting

4. Recommend a lighting system for each of the following situations. State reasons for each recommendation. Assume that each situation requires average overall lighting (ignore task lighting). Be brief.

A. A small manufacturing plant $\left(1200 \mathrm{ft}^{2}\right)$ plant operates 8 hours per day. The ceiling height is 12 feet. The plant is closed on Saturday and Sunday.

B. A large plant $\left(200,000 \mathrm{ft}^{2}\right)$ operates continuously on 3 shifts. The ceiling height is $22 \mathrm{ft}$. The plant manufactures yarn, and each lot is dyed a unique color. The dye colors cover the entire spectrum. 
C. A moderately sized plant $\left(60,000 \mathrm{ft}^{2}\right)$ with $20 \mathrm{ft}$ ceilings operates continuously over 3 shifts. Color determination requirements are not demanding.

D. A valve manufacturer has a large outdoor storage area for large castings. The plant operates 3 shifts, 5 days per week. Forklift trucks drive outside, pick up a casting, and take it to a machining center inside. Approximately 3 trucks per hour go outside. How would you light the outside storage area?

General

5. Define "energy management." Compare and contrast it to energy conservation.

\section{Electricity}

6. Using the rate schedule of Problem 1 , calculate the cost of running a $50 \mathrm{hp}$ motor.

A. 24 hours per day

B. 16 hours per day (during 2nd and 3rd shift).

Ignore ratchets and power factor. Assume that the company peaks at 2:30 $\mathrm{p.m}$. with a very large demand, then power requirements drop significantly for the rest of the day. $1 \mathrm{hp}=0.746 \mathrm{~kW}$.

Electric Rate Schedule

7. Calculate the power factor penalty (one month only) in dollars for the following conditions under the rate schedules shown. For each, state what capacitance would be required to remove the penalty.

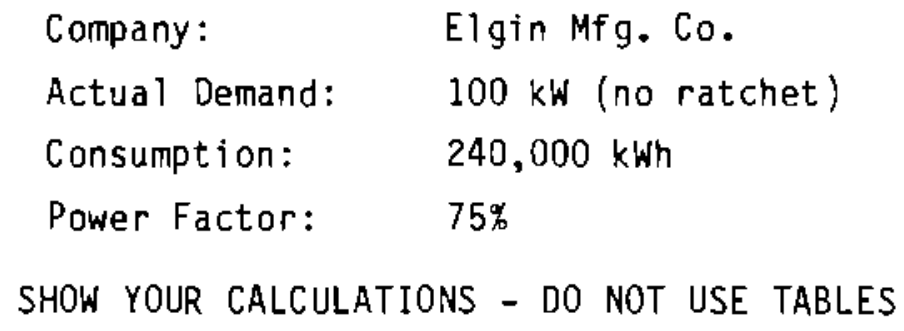


A. Rate Schedule 1

Demand Charge $\$ 4.00 / \mathrm{kW}$

Consumption Charge $\$ 0.04 / \mathrm{kWh}$ (no fuel cost adjustment)

Billed Demand = Actual Demand $(0.8 /$ actual pf).

B. Rate Schedule 2

Demand Charge $\$ 4.00 / k i l o v o l t-a m p e r e(k V a)$

Consumption Charge $\$ 0.04 / \mathrm{kWh}$

\section{Water Heat Recovery}

8. An air compressor is constantly circulating cooling water at 3 gallons per minute. If the water can be reused as rinse tank makeup, what is the dollar savings in energy and water for the parameters below? Assume that the compressor is used 6000 hours per year; water cost is $\$ 1.50$ per

1000 gallons.

A. Temp $\mathrm{H}_{2} \mathrm{O}$ in: $60^{\circ} \mathrm{F}$ : Boiler eff. (to heat rinse tank) 0.8

B. Temp $\mathrm{H}_{2} \mathrm{O}$ out: $110^{\circ} \mathrm{F}$ : Gas cost $\$ 6.00 / 10^{6} \mathrm{Btu}$.

(Assume water is off when the compressor is off.)

EMCS

9. Briefly define each of the following control strategies for energy savings:

A. Optimum start stop

B. Chilled water temperature reset

C. Ventilation economizer (enthalpy control)

D. Duty cycling

E. Demand limiting

F. Night setback.

HVAC

10. While doing a ventilation study for a plant, you find that 2,000 cfm of inside (conditioned) air is being needlessly exhausted. For the conditions below determine the added heating and cooling cost. Ignore any horsepower savings on exhaust fans. 
Inside conditions:

Outside winter average

Outside summer average

Air condit. eff. 2.5

Heating eff. $\quad 0.75$ $70^{\circ} \mathrm{F} 50 \% \mathrm{RH}$ (relative humidity)

$40^{\circ} \mathrm{F} 50 \%$ RH ( 120 days $-24 \mathrm{~h}$ per day)

$85^{\circ} \mathrm{F} 50 \%$ RH ( 90 days $-24 \mathrm{~h}$ per day)

Cost of elec. $=\$ 0.06 / \mathrm{kWh}$

Cost of gas $=\$ 6.00 / 10^{6} \mathrm{Btu}$

A. Ignore the impact of humidity

B. Include the impact of humidity.

\section{Facility Design}

11. For a one-story manufacturing plant, as shown below, discuss the placement of tinted glass, i.e., what should be tinted. Assume the plant is heated and cooled. Assume the plant is located in Tennessee.

$\hat{N}$

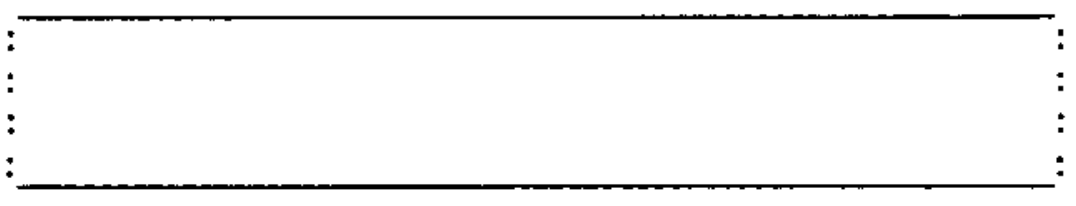

HVAC

12. Discuss briefly why variable air volume units save energy when compared to conventional dual duct, multizone, or terminal reheat systems.

13. Discuss briefly why closed-loop heat pump systems (see sketch below) often work well in large office buildings.

Heat

Pumps

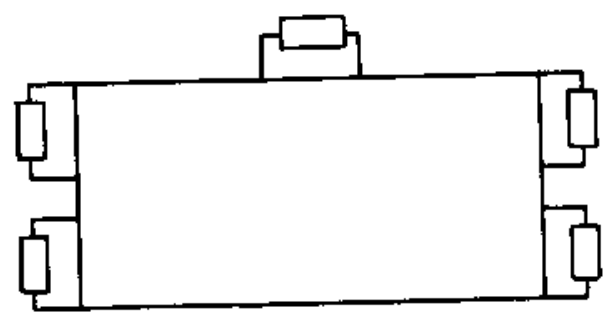

Heat Pumps

Circulating

Water Loop 


\section{Cooling Towers}

14. Discuss briefly the difference between "strainer cycle" and "thermo cycle" measures for using cooling tower water for energy savings.

\section{Electric Rate Schedule}

15. A manufacturing plant has the following characteristics:

A. Location: Oklahoma City, OkTahoma

B. Consumption $125,000 \mathrm{kWh}$ per $\mathrm{h}$

C. Demand (actual): $420 \mathrm{~kW}$

D. Previous Peak - preceding 12 months $=600 \mathrm{~kW}$

E. Billing Period: June, 30 days

F. Fuel cost pass through $\$ 0.0189 / \mathrm{kWh}$

G. Power factor Actual $=0.72$

Power factor Base $=0.80$.

Calculate the total bill for $O G$ and E's LPL rate schedule (substitute a local one).

1. Don't worry about a minimum bill.

2. No franchise payment is required.

3. No delivery voltage surcharge or discount is used.

\section{General}

16. Define energy management. List two examples of energy management that do not involve energy conservation.

\section{Combustion Flue Gas}

17. Draw the lines in the graph below (approximations only) for $\mathrm{O}_{2}, \mathrm{CO}_{2}, \mathrm{CO}$, $\mathrm{H}_{2}$, and methane $\mathrm{CH}_{4}$. Using that plot, state why a good combustion air program is difficult to run when based on tests of one constituent only. 
Composition

Percent

By Volume

Combustion Air

Boilers

18. You encounter a boiler running $\left(9 \times 10^{6}\right.$ Btu per hour $80 \%$ of the time (full time $=8760 \mathrm{~h} / \mathrm{yr}$ ). The boiler burns natural gas. Your combustion test shows $8 \% \mathrm{O}_{2}$ and a stack temperature of $600^{\circ} \mathrm{F}$.

What present excess air are you utilizing? What would you recommend as a goal? What would the dollar (\$) savings be? Assume that you are burning natural gas at $\$ 5.80$ per thousand cubic feet.

\section{Waste Heat Recovery}

19. In doing an audit of a large forging operation, you find a natural-gas rotary hearth furnace exhausting $1000 \mathrm{lb} / \mathrm{min}$ of stack gases $1700^{\circ} \mathrm{F}$. You are running at $10 \%$ excess air. Using a condensing heat exchanger, you feel you can cool the exhaust gases to $100^{\circ} \mathrm{F}$ and generate steam. Considering only sensible heat, what is the savings in Btu?

Boilers

20. In a boiler study, you find the following parameters for the water Solids in make up, ppm 400

Boiler design, ppm $\quad 5000$

Present condensate return 25\%

An expenditure of $\$ 2,000$ would increase the condensate return to $50 \%$. If the boiler is $80 \%$ efficient and consumes natural gas at $\$ 6 / 10^{6}$ Btu is the project worthwhile? Assume the blowdown is managed carefully to what 
it should be, and consider energy savings only. Steam production is $5000 \mathrm{lb} / \mathrm{h}$; makeup water is $60^{\circ} \mathrm{F}$. Drum pressure is $100 \mathrm{psig}$. The boiler is used $8000 \mathrm{~h} / \mathrm{yr}$.

\section{$\underline{\text { Lighting }}$}

21. In a lighting audit, you find 300 recessed fixtures with $150 \mathrm{w}$ flood lights. You feel you could remove 20 of these and replace the others with $75 \mathrm{~W}$ ER bulbs. At $\$ 4.00 / \mathrm{kW}$ and $\$ 0.05 / \mathrm{kWh}$, what is the annual dollar savings in energy? The bulbs burn $12 \mathrm{~h}$ per day, 6 days per week.

Insulation

22. You find $100 \mathrm{ft}$ of uninsulated steam line $3-1 / 2 \mathrm{in}$. nominal pipe carrying steam at $300^{\circ} \mathrm{F}$. Calculate the heat loss in Btu/h before and after adding l-in. foil-coated fiberglass insulation.

$\underline{\text { HVAC }}$

23. You have installed a dry-bulb economizer control unit for an air conditioner in ----- City. Return air is normally $75^{\circ} \mathrm{F}$. Your system is designed to utilize $1000 \mathrm{cfm}$ of outside air whenever the outside dry bulb is below $75^{\circ} \mathrm{F}$. Using the bin data attached, calculate the dollar savings for the month of July. Assume the return air is reduced by $1000 \mathrm{cfm}$ when outside air is used. The unit has a coefficiency of performance (COP) of 2.2 and an energy cost of $\$ 0.09 / \mathrm{kWh}$ (ignore demand).

\section{Electric Rate Schedule}

24. At $\$ 6.00 / \mathrm{kW}$ per month, calculate the annual demand bill for the following profile. The previous high demand was $1000 \mathrm{~kW}$ and the ratchet is $70 \%$.

\begin{tabular}{|c|c|c|c|c|c|c|c|c|c|c|c|c|}
\hline Month & $\mathrm{J}$ & $\mathrm{F}$ & $M$ & A & $M$ & $\mathrm{~J}$ & J & A & $S$ & 0 & $\mathrm{~N}$ & D \\
\hline Actual $\mathrm{kW}$ & : 600 & 500 & 800 & 900 & 800 & 900 & 1000 & 900 & 700 & 600 & 700 & 600 \\
\hline
\end{tabular}


General

25. You are a young engineer working for Ace Manufacturing. You have approached your plant manager about starting an Energy Management program. He asks you the following questions.

A. "What is Energy Management?"

B. "List three typical energy management studies."

C. "Distinguish between a gross audit and a detailed audit."

D. "Why do you say that energy management is the most economical source of new energy today?"

Waste Heat Boiler

26. For the furnace in Problem 3, you are considering installation of a waste heat boiler. The manufacturer states that the boiler-allowable concentration of impurities is 5000 ppm: your makeup water has 400 ppm. Assuming your final stack gas temperature is $300^{\circ} \mathrm{F}$, how many pounds of 150-psigsaturated steam can you produce? Assume your feedwater temperature is $200^{\circ} \mathrm{F}$. Flue gas flow is $25,000 \mathrm{lb} / \mathrm{h}$. What is the dollar savings? boiler efficiency is $80 \%$.

Waste Heat Recovery

27. You are considering an investment in a recuperator to preheat combustion air for a heat-treating furnace. The fuel is natural gas for a furnace rated at 75 per million Btu per $h$. You are running at full load. The present flue-gas temperature is $800^{\circ} \mathrm{F}$ and ambient air is at $70^{\circ} \mathrm{F}$. You are paying a $\$ 3$ per thousand cubic feet of gas on the average, but you consume enough that your marginal price is $\$ 2$ per thousand cubic feet. If the recuperator cost is $\$ 200,000$ installed, what is the payback? Assume that you wish to cool exhaust gases to no less than $300^{\circ} \mathrm{F}$.

Boilers

28. You are working with a boiler plant with a total capacity of 400,000 $1 \mathrm{~b} / \mathrm{h}$. There are three boilers rated at 200,000; 100,000; and 100,000 1b/h each. Steam is supplied at $500 \mathrm{psig} 600^{\circ} \mathrm{F}$. Operating demand varies from $100,000 \mathrm{lb} / \mathrm{h}$ to $250,000 \mathrm{lb} / \mathrm{h}$ peak. Given the chart below, show how you 
$100,000 \mathrm{lb} / \mathrm{h}$ to $250,000 \mathrm{lb} / \mathrm{h}$ peak. Given the chart below, show how you would determine optimum loading for each of the three boilers at a total plant load of $100,000 \mathrm{lb} / \mathrm{h} ; 125,000 \mathrm{1b} / \mathrm{h} ; 150,000 \mathrm{lb} / \mathrm{h} ; 175,000 \mathrm{lb} / \mathrm{h}$; $200,000 \mathrm{lb} / \mathrm{h} ; 225,000 \mathrm{lb} / \mathrm{h}$; and $250,000 \mathrm{lb} / \mathrm{h}$. Demonstrate by calculating the optimum loading profile for a plant load of $175,000 \mathrm{lb} / \mathrm{h}$.

$$
\begin{gathered}
\text { Boiler } 1 \\
100,00016 / \mathrm{h} \text { Cap }
\end{gathered}
$$

Load $\mathrm{O}_{2} \quad$ Stack Temperature,

$\frac{\text { Percent }}{100} \frac{\text { Percent }}{2} \frac{\text { Degree Fahrenheit }}{500}$

75

50

25
3

3

4
550

600

600
Boiler 2

\begin{tabular}{|c|c|c|}
\hline $\begin{array}{l}\text { Load } \\
\text { Percent }\end{array}$ & $\begin{array}{c}\mathrm{O}_{2} \\
\text { Percent }\end{array}$ & $\begin{array}{l}\text { Stack Temperature } \\
\text { Degree Fahrenheit }\end{array}$ \\
\hline 100 & 3 & 500 \\
\hline 75 & 4 & 500 \\
\hline 50 & 4 & 550 \\
\hline 25 & 5 & 600 \\
\hline
\end{tabular}

$100,000 \mathrm{lb} / \mathrm{h}$ Cap

\begin{tabular}{|c|c|c|c|}
\hline \multicolumn{4}{|c|}{$\begin{array}{c}\text { Boiler } 3 \\
200,0001 \mathrm{~b} / \mathrm{h} \text { Cap }\end{array}$} \\
\hline $\begin{array}{l}\text { Load } \\
\text { Percent }\end{array}$ & $\begin{array}{c}\mathrm{O}_{2} \\
\text { Percent } \\
\end{array}$ & $\begin{array}{l}\text { Stack } \\
\text { Degree }\end{array}$ & $\begin{array}{l}\text { Temperature, } \\
\text { Fahrenheit }\end{array}$ \\
\hline 100 & 2 & & 350 \\
\hline 75 & 2 & & 400 \\
\hline 50 & 2 & & 450 \\
\hline
\end{tabular}

General

29. Define energy management, and discuss why it is important for industry today.

Heat Balance

30. In conducting an energy audit, you find a large industrial furnace operating as shown in the figure. Construct a heat balance diagram (with numbers on all inputs and outputs). Identify all the potential waste-heat sources, and list one good application for each. All gas and air flow is standard cubic feet (scf). (Assume all materials have 0 enthalpy $32^{\circ} \mathrm{F}$.) 


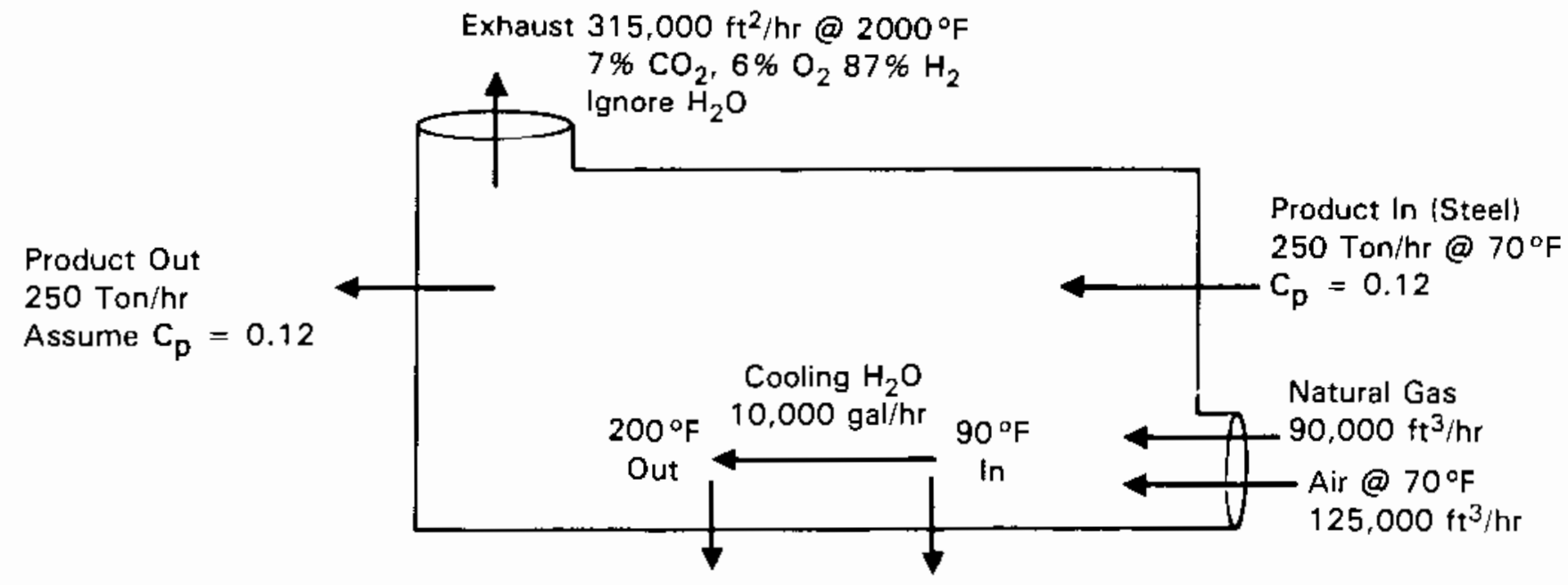

31. In the problem above, exhaust flow was stated in scf. What is the actual flow at $2000^{\circ} \mathrm{F}$ ?

Electric Rate Schedule

32. Given the following electrical parameters for Ace Manufacturing, what are the savings for reducing August demand to $900 \mathrm{~kW}$ ? Note, there is a ratchet clause (no demand shall be less than $60 \%$ of the previous 12-month peak.) Assume all years have monthly demands as shown.

\begin{tabular}{|c|c|c|c|c|c|}
\hline \multirow[b]{2}{*}{ Month } & \multicolumn{3}{|c|}{$\begin{array}{l}\text { Charge } \$ 6.00 / \mathrm{kW} \text { June through } \\
\$ 4.00 / \mathrm{kW} \text { 0ctober through May }\end{array}$} & \multicolumn{2}{|c|}{ September } \\
\hline & $\begin{array}{c}\text { Actual, } \\
\mathrm{kW}\end{array}$ & $\begin{array}{c}\mathrm{Bi} l l e d, \\
\mathrm{~kW} \\
\end{array}$ & Month & $\begin{array}{c}\text { Actual, } \\
\mathrm{kW}\end{array}$ & $\begin{array}{c}\text { Billed, } \\
\mathrm{kW}\end{array}$ \\
\hline Jan. & 450 & 600 & Juty & 900 & 900 \\
\hline Feb. & 375 & 600 & Aug. & 1000 & 1000 \\
\hline March & 475 & 600 & Sept. & 800 & 800 \\
\hline April & 650 & 650 & Oct. & 700 & 700 \\
\hline May & 675 & 675 & Nov. & 400 & 600 \\
\hline June & 700 & 700 & Dec. & 400 & 600 \\
\hline
\end{tabular}




\section{$\underline{\text { Lighting }}$}

33. Your plant has decided to convert from mercury vapor to high pressure sodium (HPS). The plant has 250 mercury vapor fixtures at $1150 \mathrm{~W}$ each including ballast. Your find that you can replace those with 250 HPS fixtures each at $450 \mathrm{~W}$ including ballast. For the parameters shown below, what is the payback on the investment? Ignore ratchet clauses and the impacts of heating and air conditioning. The lights are used $8000 \mathrm{~h}$ per year.

\begin{tabular}{|c|c|}
\hline Mercury Vapor & High Pressure Sodium \\
\hline 50,000 lumen/fixture & 45,000 lumen/fixture \\
\hline 18,000 h bulb life & $24,000 \mathrm{~h}$ bulb Tife \\
\hline$\$ 35.00$ per bulb cost & $\begin{array}{l}\$ 40.00 \text { per bulb cost } \\
\$ 250.00 \text { per fixture cost } \\
\text { (including installation) }\end{array}$ \\
\hline
\end{tabular}

$\begin{array}{ll}\text { Consumption Charges } & \$ 0.06 / \mathrm{kWh} \text { June through September } \\ & \$ 0.04 / \mathrm{kWh} \text { October through May } \\ \text { Demand Charges } & \$ 5.00 / \mathrm{kW} \text { June through September } \\ & \$ 3.50 / \mathrm{kW} \text { October through May }\end{array}$

Boilers

34. A $100,000 \mathrm{lb} / \mathrm{h}$ boiler has been operating at a maximum concentration of $4500 \mathrm{ppm}$ with $40 \%$ condensate return. The condensate return can be increased to $75 \%$ by installing additional traps, pipes, and receiver tanks at a cost of $\$ 20,000$. The boiler operates 8000 per year at a $75 \%$ load, producing saturated steam at 100 pounds per square inch absolute (psia). Is the project worthwhile? The fuel is natural gas costing $\$ 3.00 / 10^{6} \mathrm{Btu}$. Show the savings for energy, water, and water treatment. Water costs $\$ 1.50 / 1000$ gallons and treatment costs $\$ 0.75 / 1000$ gallans. Makeup water has $400 \mathrm{ppm}$ impurities. Assume that condensate is returned as 100 psia saturated liquid.

\section{Steam Traps}

35. In doing an energy audit, you find a cement-curing furnace heated by live injection of steam. You are replacing the steam trap. Discuss whether or not you should buy a trap designed to fail open or shut. Explain why. 
Heat Loss/Gain

36. Given a wall constructed as below, what is the annual heat gain in an area with $3000^{\circ} \mathrm{F}$ cooling degree days? What is the annual heat loss in an area with $5000^{\circ} \mathrm{F}$ heating degree days?

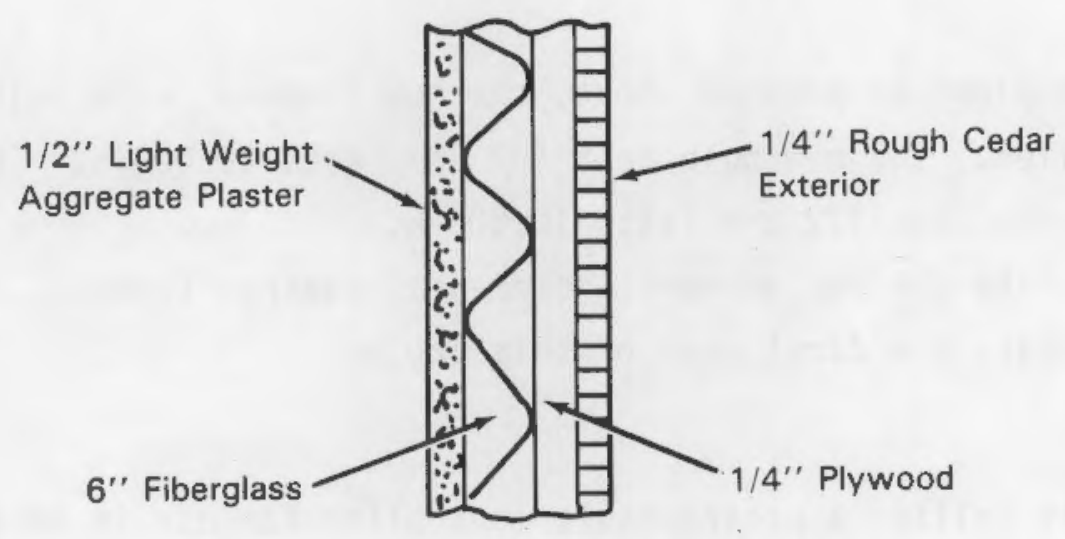

$\underline{\text { Lighting }}$

37. You are working with Ajax, Inc., a highly profitable manufacturer of beach balls. The company operates three 8-hour shifts, five days per week with two weeks off each summer for vacation. Their plant is presently lit with 100 mercury vapor lights of $1000 \mathrm{~W}$ each including ballast. You have recommended that they switch to 100 high-pressure sodium lights of $400 \mathrm{~W}$ each. Other pertinent data is given below:

Electrical Costs

Demand $\$ 4.00 / \mathrm{kW}$ mo

Energy $\$ 0.03 / \mathrm{kWh}$ (including fuel adj.)

Cooling - Heating Parameters (heating is done with gas)

Heating degree days - 4000

Cooling degree days - 1200

Heating plant efficiency 0.8

Cooling plant efficiency - 2.9

Gas cost - $\$ 3.50 / 10^{6}$ Btu.

Cooling is used for the first shift only (12 weeks).

Heating is used for all three shifts (15 weeks). 
Calculate the:

A. estimated electrical savings in $\mathrm{kWh}$ and dollars per year

B. estimated cooling savings in kWh and dollars

C. estimated heating effect in $10^{6}$ Btu and dollars

D. Net dollar savings (not including replacements).

Lighting

38. In the same plant as problem above, the new fixture (with bulb) is $\$ 250$ each installed. The new bulb cost $\$ 40$ and lasts $20,000 \mathrm{~h}$. The old (mercury) bulb cost $\$ 22$ and lasts $10,000 \mathrm{~h}$.

A. Calculate the replacement incremental savings (costs).

B. Calculate the first cost of this project.

EMCS

39. A company is selling a programmable controller for use in managing their electrical consumption better. The company intends to cycle the air conditioning equipment as follows.

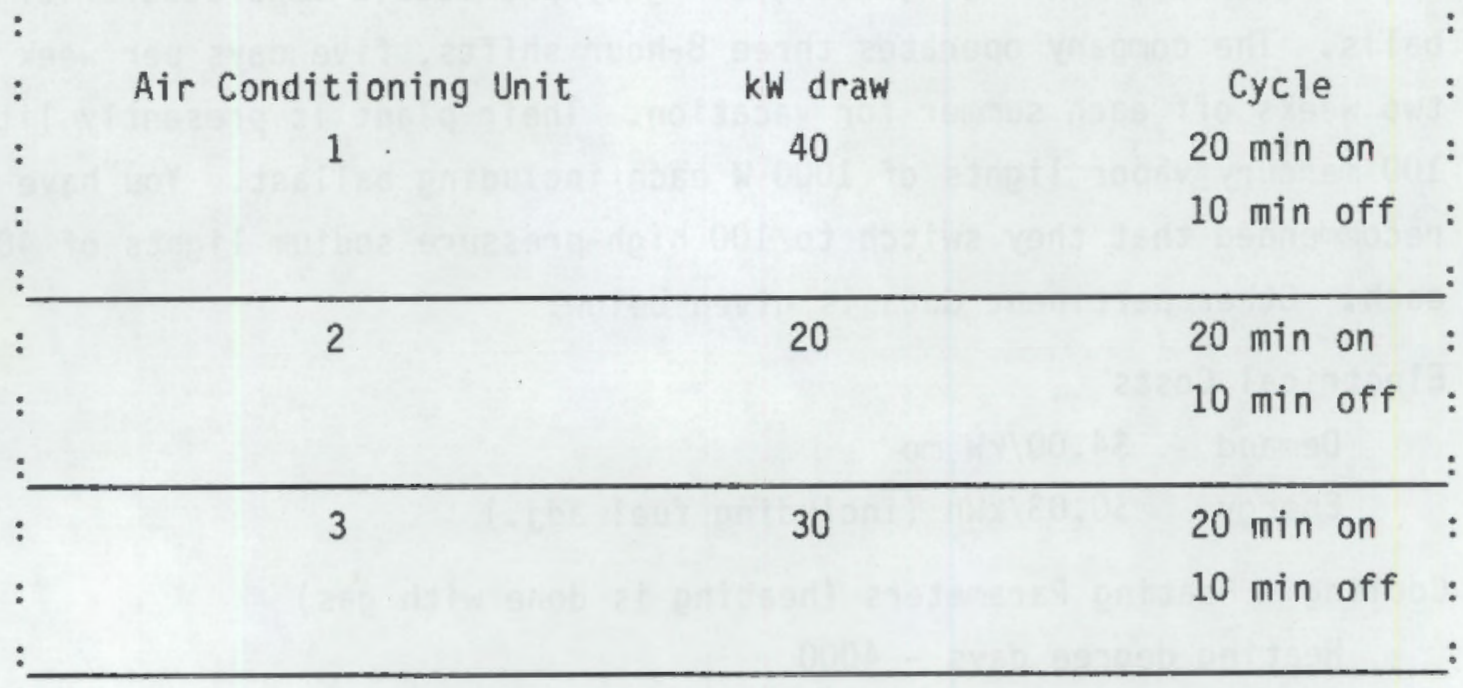

The company is paying $\$ 4.00 / \mathrm{kW}$ month for demand and $\$ 0.04 / \mathrm{kWh}$ for electrical energy. The cycling is such that one unit is always off. If the company operates $10 \mathrm{~h}$ per day, 250 days per year and air conditioning is supplied 3 mo of the year, what is the saving in kWh and dollars? 


\section{Excess Air}

40. In analyzing a gas-fired furnace of $5010^{6}$ Btu-rated capacity (burns natural gas costing $\left.\$ 4.00 / 10^{6} \mathrm{Btu}\right)$, you find the following:

Flue Gases

$\begin{array}{rc}\mathrm{CO}_{2} & 8 \% \\ \mathrm{O}_{2} & 6 \% \\ \text { Temperature } & 525^{\circ} \mathrm{F} .\end{array}$

A. What are the savings for correcting excess air?

B. What would be the savings for installation of turbulators that would reduce the stack temperature to $300^{\circ} \mathrm{F}$ ?

\section{Window Treatment}

41. In auditing an industrial plant, you find 200 windows each $3 \mathrm{ft} \times 5 \mathrm{ft}$ that serve little purpose except to provide natural lighting. The foreman does not want you to block his windows, so you propose "wonderstick." "Wonderstick" is an adhesive-backed transparent material that insulates the window but does not block light. Wonderstick's R-value is 3.0. It costs $\$ 0.50 / \mathrm{ft}^{2}$ installed. If the gas-fired heating plant efficiency is 0.7 , gas costs $\$ 3.00 / 10^{6} \mathrm{Btu}$, and the plant experiences 5000 heating degree days per year, what are the heating savings in dollars? Is the project worthwhile? The plant operates $24 \mathrm{~h}$ per day, 365 days per year.

HVAC, EMCS

42. For Bismark Manufacturing, estimate the savings per year $\left(10^{6} \mathrm{Btu}\right)$ for a 15-degree night setback. The company gas consumption is shown for the past year. Assume they have a heating demand of 5000 degree days. (Note: provide bin data or rule of thumb.) 


\begin{tabular}{lc} 
Month & Consumption, $10^{9}$ Btu \\
\cline { 2 - 2 } Jan. & 3000 \\
Feb. & 2000 \\
Mar. & 1500 \\
Apr. & 1400 \\
May & 600 \\
June & 550 \\
July & 600 \\
Aug. & 550 \\
Sept. & 600 \\
Oct. & 1200 \\
Nov. & 1500 \\
Dec. & 2000
\end{tabular}

\section{Electricity}

43. Given a 3-phase electrical motor with a phase angle (theta) of 30 degrees and an average draw of $15 \mathrm{~A}$ at $200 \mathrm{~V}$ :

A. What is the power factor?

B. What is the hp of the motor, assuming a physical efficiency of $85 \%$ ?

Combustion

44. Given the following balanced combustion equation for the burning of methane and the fact that air is $23.3 \% \mathrm{O}_{2}$ by weight, how many pounds of air are required to combust $10 \mathrm{lb}$ of methane? Assume perfect mixing and combustion.

$$
\mathrm{CH}_{4}+2 \mathrm{O}_{2}=\mathrm{CO}_{2}+2 \mathrm{H}_{2} \mathrm{O}
$$




\begin{tabular}{lccc} 
& Atomic Weight & & Molecular Weight \\
\cline { 2 - 3 } Hydrogen & 1 & 2 \\
Carbon & 12 & 12 \\
Nitrogen & 14 & 28 \\
Oxygen & 16 & 32 \\
Carbon Dioxide & -- & 44 \\
Methane & -- & 16
\end{tabular}

\section{Steam}

45. $2001 \mathrm{bm}$ of steam at $40 \mathrm{psia}$ and $400^{\circ} \mathrm{F}$ is mixed with $1001 \mathrm{bm}$ of $90 \%$ quality steam at 40 psia. Assuming no loss in heat and a constant pressure, what is the final state?

General

46. Some have stated that the U.S. energy crisis is not caused by the quantity of energy but rather by the choice of energy sources. Discuss this briefly giving some statistics to support your beliefs.

47. What is the chief argument against the breeder reactor and spent fuel reprocessing?

48. What is the single most important element for a successful energy management program? Justify your answer.

Audits

49. You work for the plant manager. You have been assigned the responsibility of initiating an energy management program. Your manager asks you:

(A) What is a gross audit, and why should we do one? Also, (B) What is a detailed audit (connected load), and should we do it? Tell me why or why not."

Answer him. 
Energy Balance

50. In your position as energy manager, you encounter several situations where you want to do an energy balance for specific pieces of equipment (SUM energy in = SUM energy out). One is a boiler producing $X$ pounds in steam per $h$ at certain conditions. Ten percent of the feedwater is new water at $50^{\circ} \mathrm{F}$, and $90 \%$ is condensate return at $190^{\circ} \mathrm{F}(10 \%$ of the steam is lost). Five percent of the steam is "blown down" (exhausted) for solids control. Describe how you would do a heat balance.

Heat Loss Insulation

51. In an energy audit, you have found a condensate return tank that is uninsulated. The diameter of the tank is $3 \mathrm{ft}$ and $5 \mathrm{ft}$ long. The surface temperature of the flat-black-colored metal tank is $270^{\circ} \mathrm{F}$. You are considering insulating the tank with 3 in. of fiberglass with an aluminum jacket. Assuming the insulation reduces the heat loss by $90 \%$ and the insulation costs $\$ 1.25 / \mathrm{ft}^{2}$ installed, what is the undiscounted payback on the project? The boiler is operated $8000 \mathrm{~h}$ per year and is $80 \%$ efficient. The ambient temperature is $70^{\circ} \mathrm{F}$. Fuel cost is $\$ 2.50$ per million Btu (natural gas). What is the total dollar savings?

Steam

52. For the same steam system as in the problem above, you found the following steam leaks. If the steam is 100-psig-saturated, what is the total dollar value (\$) of the leaks?

$\begin{array}{cc}\text { Size of Hole, Inches Diameter } & \frac{\text { Number of Leaks }}{0.1} \\ 0.25 & 8\end{array}$

\section{Steam Traps}

53. A. What is a steam trap?

B. Why is there so much fuss about monitoring steam traps?

C. Name three ways of checking steam traps.

D. What is the best way of checking these traps? 


\section{Waste Heat Recovery}

54. In a waste heat study, you have encountered a large gas-fired furnace with two primary sources of potential waste heat. They are 1) the cooling water for the furnace walls and 2) the flue gases. For the data given below, quantify the amount of waste heat available in both sources and discuss potential uses of each source. The furnace operates two 8-hour shifts per day, 250 days per year.

A. Cooling water:

$600 \mathrm{gal} / \mathrm{min}$

Outlet temperature $=150^{\circ} \mathrm{F}$

B. Flue gases

Temperature $2000^{\circ} \mathrm{F}$

Composition $7 \% \mathrm{CO}_{2}$

$8 \% \mathrm{O}_{2}$

$0 \% \mathrm{CO}$

$85 \% \mathrm{~N}_{2}$

Flow rate $410^{6} \mathrm{ft}^{3} \mathrm{~h}$.

\section{Waste Heat Recovery}

55. In another audit, someone found a large $150 \mathrm{hp}$ air compressor that was air cooled. They decided to use the air coming off the condenser as space heat and hooked it up as shown in the figure. You immediately spotted something badly wrong! Tell me what's wrong?

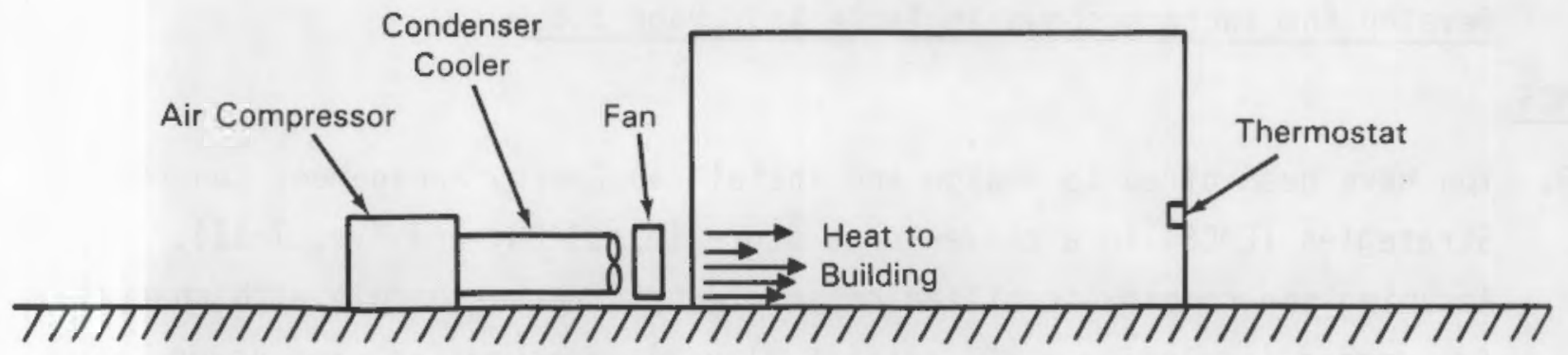


Heating, Ventilation, Air Conditioning

56. After a restudy of ventilation requirements, you find that ventilation requirements for a building can be reduced from $10,000 \mathrm{ft}^{3} / \mathrm{min}$ to $6,000 \mathrm{ft}^{3} / \mathrm{min}$. Presently, a $25 \mathrm{hp}$ motor drives the blower (assume it is correctly sized for $10,000 \mathrm{ft} 3 / \mathrm{min})$. Outside air is $25 \%$ and will stay at $25 \%$ after the reduction is made, i.e., $25 \%$ of $6000 \mathrm{ft} 3 / \mathrm{min}$. If you pay $\$ 0.03 / \mathrm{kWh}$ and $\$ 4.00 / \mathrm{kW}$ month for electrical energy and demand and $\$ 3.00 / 10^{6}$ Btu for natural gas, what is the savings for the change? Heating plant efficiency is $80 \%$, and the system operates $4000 \mathrm{~h}$ per year (assume it operates during peak times). The building is not cooled, but the fan runs for ventilation purposes. Heating degree days $=4000^{\circ} \mathrm{F}$ days. Density air is $0.07251 \mathrm{bm} / \mathrm{ft}^{3}$. Specific heat of air is $0.248 \mathrm{Btu} / \mathrm{lbm}{ }^{\circ} \mathrm{F}$.

Wind

57. We know the wind energy conversion equation

$$
P / A=1 / 2 V^{3}
$$

is equivalent to

$$
P / A=K V^{3}
$$

with values of $K$ as shown in the Energy Management Handbook, (Turner 1982).

Develop the factors shown in Table 163, Page 518.

EMCS

58. You have been hired to design and install an Energy Management Control Strategies (EMCS) in a convenience store (e.g., Buy and Bye, 7-11). Assuming the company is billed on an electric rate schedule with charges for demand (including a $80 \%$ ratchet clause), consumption, and power factor, design a comprehensive system assuming all ideas are cost effective. Then fill in the table below. 


\section{Likelihood of Being Cost Effective}

Equipment

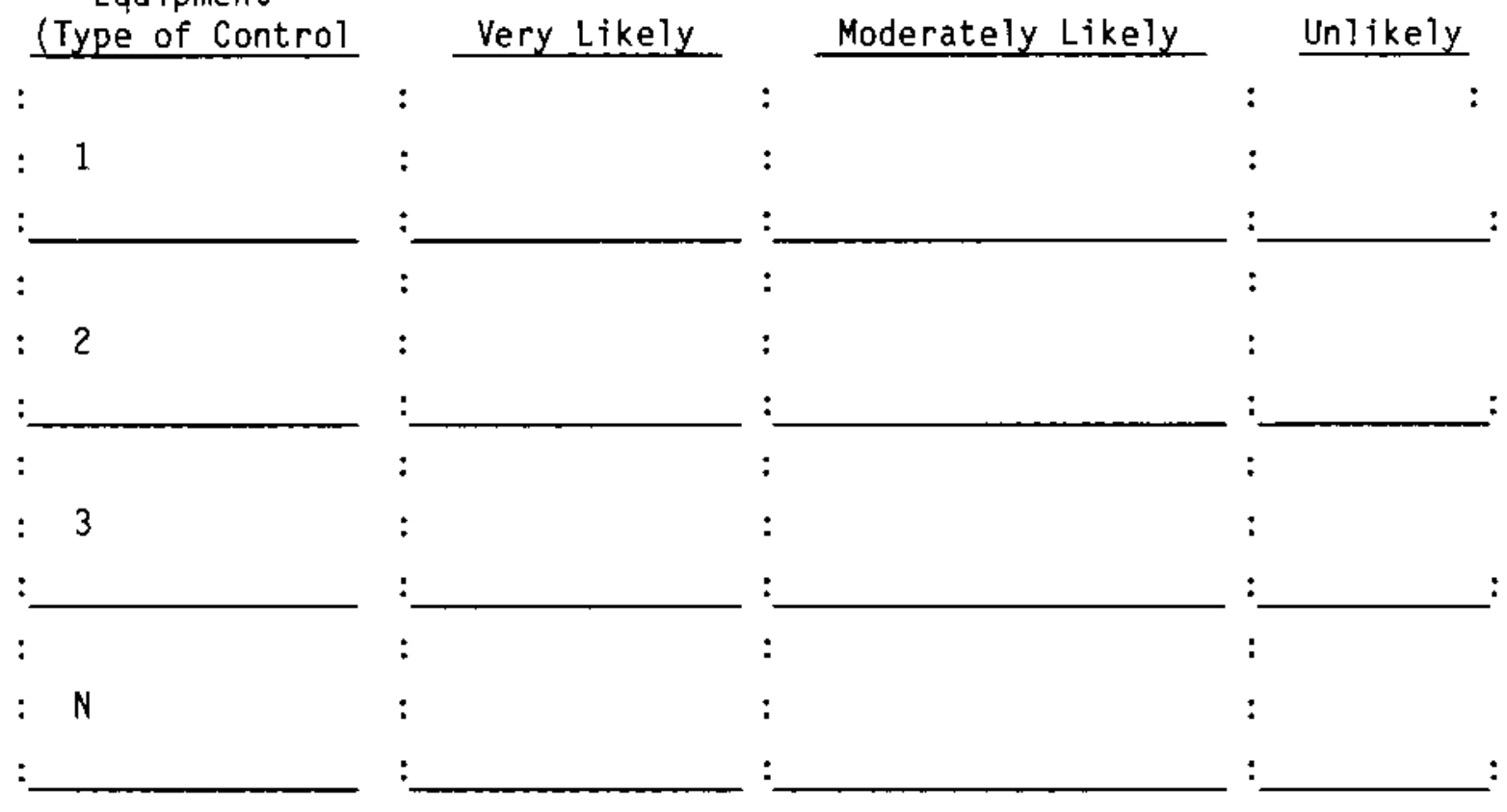

If you are uncertain, place the item in the middle column. Defend each placement with a footnote (state why).

Steam

59. You have a pressure-reducing station taking $20,0001 \mathrm{~b} / \mathrm{h}$ steam at $300 \mathrm{psig}-100^{\circ} \mathrm{F}$ superheat and throttling it down to $50 \mathrm{psig}$ steam for use in space heating. For a turbine efficiency of $65 \%$, what shaft power can be generated, and how much additional steam is necessary, if any? What is the quality of steam (\% steam and \% condensate) leaving the turbine?

\section{Cogeneration}

60. Briefly discuss what a chiller heater is, and show how it can be considered to be cogeneration. Develop a case study showing good economic analysis. For the first cost, make any reasonable assumption.

Boiler

61. An $80,000 \mathrm{lb} / \mathrm{h}$ boiler has been operating at a maximum impurity concentration of $3000 \mathrm{ppm}$ with $50 \%$ condensate return. Makeup water has $450 \mathrm{ppm}$ impurities. If the condensate return can be increased to $75 \%$, calculate 
the savings from reduced blowdown. The unit efficiency is 0.8 , natural gas fuel cost $\$ 3.00 / 10^{6}$ Btu and operating time is $8000 \mathrm{~h}$ per year. Steam pressure is 100 parts per square inch gage (psig).

\section{Steam Trap}

62. An inverted bucket with a $1 / 4 \mathrm{in}$. orifice is found to be stuck open. How much steam is being lost? Using the parameters from the problem above, how much is that costing?

63. Briefly discuss what ill effects can occur if a steam trap fails open. Repeat for failing closed.

\section{Cogeneration}

64. For cogeneration distinguish between

A. topping cycles

B. bottaming cycles

C. combined cycles.

65. Briefly describe a typical combined cycle.

Waste Heat Recovery

66. In a recuperator study, exhaust stack temperatures are $1100^{\circ} \mathrm{F}$ and combustion (room) air is supplied at $70^{\circ} \mathrm{F}$. A recuperator will yield combustion air of $500^{\circ} \mathrm{F}$. At $\$ 3.00$ per million Btu fuel cost and a required 3-year undiscounted payback, how much can be spent on the recuperator? Assume the unit is fired $8000 \mathrm{~h}$ per year, is 100\% efficient, and presently burns $20,000 \mathrm{ft}^{3}$ of natural gas per hour. Natural gas cost is $\$ 3.00$ per million Btu. Assume 13 lb of air are required per pound of natural gas. The density of natural gas is about $0.625 \mathrm{lbm} / \mathrm{ft}^{3}$.

$\underline{\text { HVAC }}$

67. During an energy audit, it is found that one large exhaust fan operating $8000 \mathrm{~h} /$ year presently exhausts $36,000 \mathrm{cfm}$ of air that is "made up" by infiltration. Studies show that $20,000 \mathrm{cfm}$ would be sufficient. If the fan is driven by a 30 hp motor operating at 100\% load, what would the savings be for A) fan hp reduction, B) reduced heating costs, and C) reduced cooling costs. Air conditioning is provided at an efficiency of 2.5 (COP) 
and heating at an efficiency of 0.7 . Heating fuel costs $\$ 3.00 / 10^{6} \mathrm{Btu}$; electricity for cooling costs $\$ 0.05$ per $\mathrm{kWh}$. Heating degree days $=4000$, and cooling degree days $=2000$. Specific heat of air $=0.02 \mathrm{Btu} / \mathrm{ft}^{3}$.

$\underline{\text { Steam }}$

68. A condensate return system returns condensate at 30 psig to an unpressurized - vented receiver tank. What percentage of the condensate is being lost as flash steam? (Calculate - do not use tables.) List the things that can be done to recover some of that lost steam.

69. A $100,000 \mathrm{lb} / \mathrm{h}$ boiler has been operating at $25 \%$ condensate return. Makeup water has 250 pprn impurities and the boiler can handle 3000 ppm. What would the savings be if the condensate return is increased to $50 \%$ ? (State savings in Btu and dollars.) Fuel is natural gas costing $\$ 5.00 / 10^{6} \mathrm{Btu}$, and the boiler is $80 \%$ efficient. Assume the boiler operates at $75,000 \mathrm{lb} / \mathrm{h}$ consistently for $8000 \mathrm{~h}$ per year. (Calculate - use no tables other than steam tables.) Boiler drum pressure is 100 psig.

General

70. Briefly discuss why it may be more important for a corporate level energy management program to have a technical committee than for a local plant. Assume both already have steering committees.

Combustion

71. Given the following balanced combustion equation for the burning of methane and the fact that air is $23.2 \% 0_{2}$ by weight, how many pounds of air are required for each pound of methane? Assume perfect mixing and combustion.

$$
\mathrm{CH}_{4}+2 \mathrm{O}_{2} \longrightarrow \quad \mathrm{CO}_{2}+2 \mathrm{H}_{2} \mathrm{O}
$$




\section{Atomic Weight}

Hydrogen

Carbon

Nitrogen

oxygen
1

12

14

16

Assuming that air is $100-23.2=76.8 \%$ nitrogen, how much nitrogen goes up the stack for each pound of methane? Why is that a problem? What can be done about it?

Flue Gas

72. You measure flue gas composition in a 50 million Btu per hour furnace and find that $\mathrm{O}_{2}$ is $8 \%$ and stack temperature is $800^{\circ} \mathrm{F}$. What is the savings for correcting that to the optimum realistic value? The fuel is natural gas costing $\$ 3.00 / 10^{6}$ Btu. Assume the furnace operates at full capacity, $8760 \mathrm{~h} /$ year. You may use any tables you wish.

Waste Heat Recovery

73. While studying the furnace above, you realize the flue gas temperature is pretty high. List at least three ways you could recover some of this heat.

\section{Power Factor}

74. One utility bilis $\$ 1.00$ for each "excess kvar" where "excess kvars" are all those greater than $60 \%$ of the actual $\mathrm{kW}$ average demand. What is their base pf, i.e., the pf below which a penalty is incurred? Another bills for pf by expressing demand in $k$ va. What is their base $p f$ ?

\section{Air Compression}

75. During an energy audit, you encounter a relatively large air compressor. List below five items that you would check for applicability in reducing energy costs. 
$\underline{\text { Insulation }}$

76. Given a 6-in. pipe covered by 2 in. of aluminum-jacketed fiberglass insulation, what is the surface temperature of the aluminum? The pipe carries a hot fluid at $300^{\circ} \mathrm{F}$. Ambient air is $80^{\circ} \mathrm{F}$.

Water

77. In a water audit, you find many steam leaks totaling $200 \times 10^{6}$ Btu energy loss per year (from size of leaks and tables). Determine how much water is being lost in these leaks. Steam is supplied at 120 psig saturated and makeup water is $70^{\circ} \mathrm{F}$. At $\$ 1.25 / 1000 \mathrm{gal}$, how much is the water loss costing?

Energy Accounting

78. In your energy management work with Stillwater Municipal Hospital, you decide to develop one or more "one-shot" energy productivity measures. Propose several candidates, and discuss their advantages and disadvantages.

Genera 1

79. It has been said that energy usage does not vary linearly with the level of production but that the rate of energy use, i.e., Btu unit of production does. Discuss this and develop a generalized forecasting model of energy consumption based on production only (ignore other factors). Hint: Btu/Unit of Production may drop as production increases.

\section{Energy Management Control Strategies}

80. Using an industrial setting, give me a good example of each of the following energy management control applications. For each, state the nature of the savings in the form, and enter yes or no as appropriate. 


\begin{tabular}{|c|c|c|c|}
\hline & $: \operatorname{Gas}(a)$ & $\begin{array}{r}\text { Ele } \\
S\end{array}$ & $\begin{array}{l}\text { ctricity } \\
\text { avings }\end{array}$ \\
\hline & : Savings & Demand & : Consumption \\
\hline \multirow{2}{*}{$\begin{array}{l}\text { A. } \quad \text { Demand limiting } \\
\text { Example: }\end{array}$} & $:$ & $:$ & : \\
\hline & : & : & : \\
\hline \multirow{2}{*}{$\begin{array}{l}\text { B. Optimized start stop } \\
\text { Example: }\end{array}$} & : & $:$ & : \\
\hline & $:$ & : & : \\
\hline \multirow{2}{*}{$\begin{array}{l}\text { C. Load Cycling } \\
\text { Example: }\end{array}$} & $:$ & $:$ & : \\
\hline & $:$ & : & $:$ \\
\hline \multirow{3}{*}{$\begin{array}{l}\text { D. Night Set Back } \\
\text { Example: }\end{array}$} & $:$ & $:$ & : \\
\hline & : & : & : \\
\hline & $:-$ & $\therefore$ & $\therefore-$ \\
\hline \multirow{2}{*}{$\begin{array}{l}\text { E. Optimized Air Source } \\
\text { Example: }\end{array}$} & : & $:$ & : \\
\hline & : & : & : \\
\hline \multirow{4}{*}{$\begin{array}{l}\text { F. Temperature Reset } \\
\text { Example: }\end{array}$} & $:$ & $:$ & : \\
\hline & : & $:$ & $:$ \\
\hline & $:$ & $:$ & : \\
\hline & $\therefore$ & & \\
\hline
\end{tabular}

(a) Gas or other "fuels" such as fuel oil, coal, wood, etc.

\section{Steam Traps}

81. In steam trap maintenance, sound is often used. Discuss how this works. Be specific for different types of traps.

\section{Insulation}

82. In an energy audit, you found a 4-in. dia pipe that was insulated. The pipe was carrying live superheated steam at $300^{\circ} \mathrm{F}$. The installation is indoors. You have decided to insulate the pipe with aluminum-jacketed fiberglass, but you don't know whether to use 2 in. or 3 in. Given that the 2-in. insulation costs $\$ 1.00 / \mathrm{ft}^{2}$ installed and the $3-i n$. costs $\$ 1.35 / \mathrm{ft}^{2}$ installed, which is better? You are using 3 -year payback as the decision criteria. You are paying $\$ 3.00 / 10^{6}$ Btu installed, and the boiler is $75 \%$ efficient. Ambient air is $80^{\circ} \mathrm{F}$. The boiler operates $8760 \mathrm{~h}$ per year. 
Wind

83. You are considering the use of wind-generated electricity to power an effluent treatment facility for a local manufacturing company. There is a relatively steady need of $100 \mathrm{~kW}$ for $8 \mathrm{~h}$ per day (any $8 \mathrm{~h}$ in the day). Assuming the wind speed is more than $20 \mathrm{mph}$ for $8 \mathrm{~h}$ per day, how many horizontal 5-ft dia windmills would be necessary? Conversion efficiency is $70 \%$ at the rated velocity of $20 \mathrm{mph}$.

Solar

84. As an alternative to the wind system in the problem above, you are looking at a photovoltaic system comprised of cells, each putting out $0.45 \mathrm{~V}$ and $1 \mathrm{~A}$. Assuming the power system in question is single phase and draws $440 \mathrm{~V}$ at $250 \mathrm{~A}$, what type of an array is required?

\section{Fleet Management}

85. You have been hired as energy manager for Joe Smith Office Supplies. They have a fleet of 100 trucks and small vans for delivery purposes. All trucks consume gasoline. The fleet manager asks for ideas that might reduce his fuel costs. List at least 5 such ideas. The trucks are used in town for delivery of no more than 100 miles.

Air Compression

86. In a combination water-energy management survey, you found a 100-hp air compressor that was water cooled. It was a once-through system; city water came in at $55^{\circ} \mathrm{F}$ and left at $100^{\circ} \mathrm{F}$. The flow rate was $10 \mathrm{gal}$ per minute. Assuming the water could be dumped directly into a boiler makeup tank with $1 / 2$ the heat recovered and reused, how much energy (Btu and dollars) and water (Btu and dollars) would the company save? The water costs $\$ 1.00$ per 1000 gal and sewage disposal is $\$ 0.30$ per 1000 gal. Fuel costs $\$ 2.50 / 10^{6} \mathrm{Btu}$, and the boiler is $80 \%$ efficient. All the water can be used, and both systems are "up" all the time.

\section{Cooling Tower}

87. In our discussion on water management, we looked at air fin cooling of cooling water in lieu of, or in conjunction with, water towers. 
Considering air fin cooling in conjunction with a water tower, there are two primary advantages or savings potentials. List those two.

Insulation

88. You are looking at a chilled water line (6 in.) in a process room. The water temperature is $47^{\circ} \mathrm{F}$. The room temperature is $70^{\circ} \mathrm{F}$ with $40 \%$ relative humidity. How much fiberglass insulation with kraft-paper backing is required to avoid condensation?

89. For the insulation level determined above, what is the heat gain per hour?

Wind

90. A city is considering the use of wind-generated electricity for its local sewer treatment plant. There is a relatively steady load of $150 \mathrm{~kW}$ for $10 \mathrm{~h}$ per day. Assuming that the wind speed is a constant $15 \mathrm{mph}$, how many windmills $6 \mathrm{ft}$ in dia would be required? Conversion efficiency is $65 \%$ ?

\section{Cogeneration}

91. A typical steam turbine cogeneration system is shown below. What is the overall plant efficiency with and without the process load recovery?

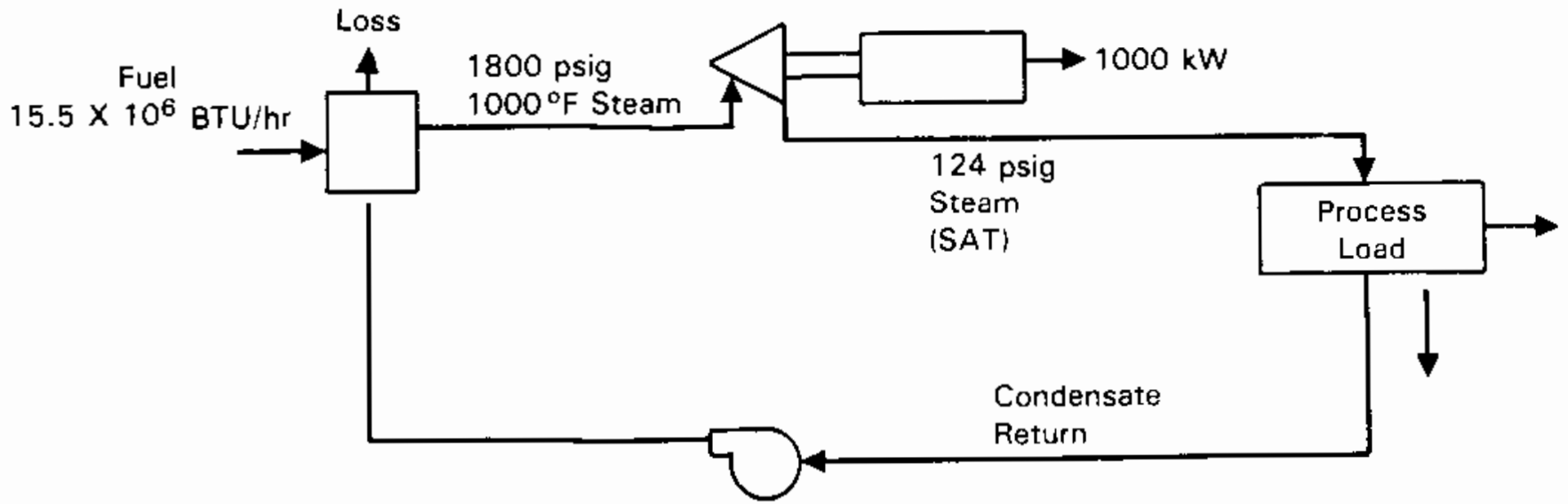

92. For the system depicted above, what is the net economic worth to a company with the parameters given below? Assume the system is baseloaded $8760 \mathrm{~h} / \mathrm{yr}$. 
Purchased electricity $\$ 0.3 / \mathrm{kWh} ; \$ 5.00 / \mathrm{kW}$-month

Fuel cost $\$ 5.00 / 10^{6} \mathrm{Btu}$

Normal Boiler Eff. $\quad$ (Process Load) 75\%

EMCS

93. For Energy Management Control Systems, define

A. Power Line Carriers

B. Direct Digital Control

C. Twisted Pairs

D. MUX

E. IMUX

F. FID

G. Optimal Start/Stop

H. Economizer (HVAC Operation)

I Duty Cycling

J. Chilled Water Temperature Reset.

Electric Rate Schedule

94. Given the attached rate schedule, calculate the monthly electric bill for Ace Manufacturing as described below:

Month:

January

kWh consumed:

100,000

$\mathrm{kW}$ (peak actual):

1,500

Power factor:

$70 \%$

No direct current motors

95. If Power ratcheted demand 70\% over the previous $12 \mathrm{mo}$, and the previous demands were $1500 \mathrm{~kW}, 1400 \mathrm{~kW}, 1300 \mathrm{~kW}, 1200 \mathrm{~kW}, 1000 \mathrm{~kW}$, $2000 \mathrm{~kW}, 1000 \mathrm{~kW}, 1000 \mathrm{~kW}, 1200 \mathrm{~kW}, 1300 \mathrm{~kW}, 2200 \mathrm{~kW}$, and $1300 \mathrm{~kW}$, respectively, what is the demand charge?

What if adjusts demand by penalizing for poor power factor (base $=80 \%$ ). Using the ratio method we discussed in class, what is the demand charge (ignore ratchet)? 
96. In conducting an audit for a manufacturing plant, you encounter a large industrial furnace with a closed firebox. You test the furnace and find the following parameters:

Stack Gas Temperature $\quad 600^{\circ} \mathrm{F}$

$\mathrm{O}_{2}$ in stack gas $10 \%$ (by volume)

Furnace Operating Capacity $100 \times 10^{6} \mathrm{Btu} / \mathrm{hr}$

Fuel cost (natural gas) $\$ 5.00 / \mathrm{mcf}$

97. Assuming the furnace above has been corrected to $10 \%$ excess air and you find $1000 \mathrm{lb} / \mathrm{h}$ of exhaust at $600^{\circ} \mathrm{F}$, what would be the maximum savings (in dollars) if you installed some type of heat recovery device? Assume the fuel replaced is natural gas at the same price.

98. Recommend and justify a lighting source for the following situations. Assume electricity rates are relatively high in all cases.

A. A large yarn manufacturer operates $24 \mathrm{~h} /$ day 365 days per year in a plant with a tall ceiling. The yarn is dyed various pastel colors that must be discerned.

B. A plant assembles components to a small chassis. The plant has a low ceiling and operates $8 \mathrm{~h}$ per day, 5 days per week.

C. A plant runs all the time. The ceiling is high, and the work is rough assembly with no color determination.

D. A large outdoor storage area needs light for security purposes onty. No one works in the yard at night, but the lights must be on all the time.

99. Given the following diagram for percent constituents in flue gases, match the gases to the lines (i.e., show which is which). 


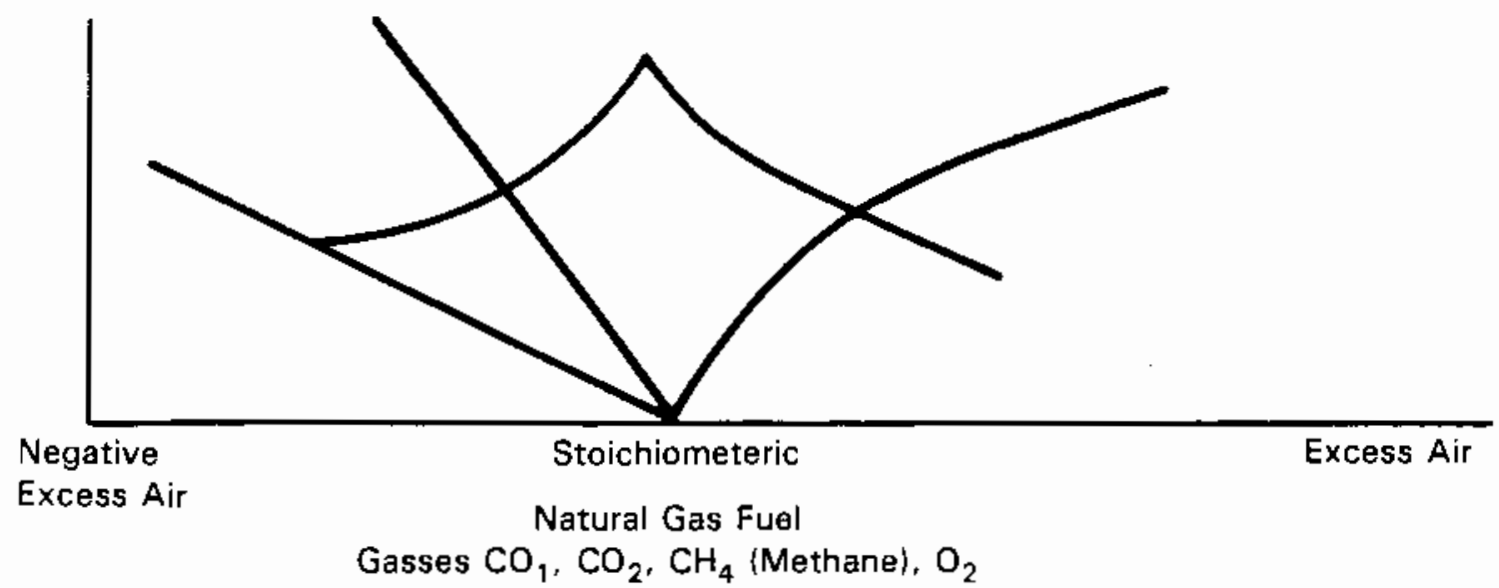

100. List 3 ways (your university) might reduce its demand charge (assume no power factor penalty or ratchet clause).

101. Define energy management.

102. The walls of a furnace are metal painted a dull green. The surface temperature is $200^{\circ} \mathrm{F}$. Calculate the heat loss per $\mathrm{ft}^{2}$ and the yearly cost of the loss. What is a reasonable savings estimate for insulating that furnace?

\section{Excess Air Control}

103. You are considering a waste heat boiler for an aluminum-can melt furnace with a stack temperature of $1200^{\circ} \mathrm{F}$. Flue gas measurement shows $4.5 \% 0_{2}$ under present conditions. The furnace has a rated $100 \times 10^{6} \mathrm{Btu} / \mathrm{hr}$ capacity but operates at $75 \%$ load most of the time. The marginal cost for natural gas is $\$ 3.00$ /thousand cubic feet. Show the savings if the furnace is adjusted for excess air control. The furnace operates $12 \mathrm{~h} /$ day, 250 days per year. 
<smiles>[131I-]</smiles> 
SELECTED ENERGY MANAGEMENT COURSES UNDERGRADUATE AND GRADUATE LEVEL

Several universities offer energy management courses. This section presents a brief description of the courses available, the prerequisites required, textbooks and references used, and course syllabi whenever available.

\section{ENERGY COURSES AT TEXAS A\&M}

Texas A\&M offers several energy management courses at both the undergraduate and graduate level. Some of the courses are presented as student syllabi, some include ABET information, and others appear in outline forms. (a)

The 400-level courses are all offered as senior level electives. The 600-level courses are offered at the graduate level only. Texas A\&M also offers energy-related courses in power engineering, solar energy, direct energy conversion, and combustion. Queries concerning courses offered at Texas A\&M should be directed to Or. Warren M. Heffington, Associate Professor and Assistant Department Head, Mechanical Engineering Department, College Station, IX 77843-3123.

The course outline for ME 436 "Heating, Ventilating, and Air Conditioning" is shown in Table 7. The text used in the course is listed at the bottom of the table.

Table 8 details "Principles of Building Energy Analysis," offered as ME 437 , a three-credit class.

The syllabus for Mechanical Engineering 438 "Energy Conservation Industry and Commerce" is presented in Table 9. Four courses are offered at the graduate leve1: ME 661 "Energy Systems," ME 662 "Energy Management in Industry," ME 664 "Energy Management in Commercial Buildings," and ME 665 "Applications of

\footnotetext{
(a) Course syllabi and outlines were provided by W. M. Heffington, Associate Professor and Assistant Department Head, Texas A\&M, Mechanical Engineering Department, College Station, Texas 77843-3123.
} 
TABLE 7. ME 436: Heating, Ventilating, and Air Conditioning--Texas A\&M

\begin{tabular}{|c|c|c|}
\hline $\begin{array}{l}\text { Closs } \\
\text { Perlad }\end{array}$ & Tople & $\begin{array}{l}\text { Reading } \\
\text { Assignment }\end{array}$ \\
\hline 1 & Introduction/Overvlew & $\rightarrow \rightarrow$ \\
\hline 2 & Refrlgeratlon EquIpment/Cycle & 8.1 to 8.7 \\
\hline 3 & Refrlgeration Cycle Revleu & 15.1 to 15.3 \\
\hline 4 & Compressors & 15.4 \\
\hline 5 & Control Valves, Real System & 15.5 to 15.6 \\
\hline 6 & AbsorptIon Refrigeration & 15.7 to 15.11 \\
\hline 7 & Heating Equipment & lecture notes \\
\hline 8 & Heating Equlpment & lecture notes \\
\hline 9 & Performance Calculatlor & lecture notes \\
\hline 10 & Molst Air Propertles & 2.1 to 2.4 \\
\hline 11 & ConditIonIng Processes & 2.5 to 2.7 \\
\hline 12 & Exam No. 1 & \\
\hline 13 & Fluld Flow/Measurement & 9.1 \\
\hline 14 & Centrlfugal Pumps & 9.2 \\
\hline 15 & Plpling System Design & 9.3 to 9.5 \\
\hline 16 & Room Alr Distribution & 10.1 to 10.3 \\
\hline 17 & Fans & 11.1 to 11.2 \\
\hline 18 & Fans and Ducts & 11.3 to 11.6 \\
\hline 19 & Duct Design: Gener of & 11.7 to 11.9 \\
\hline 20 & Duct Design: Low Veloclty & 11.10 to 11.11 \\
\hline 21 & Duct Deslgn: High Velocity & $11 \cdot 12$ \\
\hline 22 & Humldity Measurement & 12.1 to 12.4 \\
\hline 23 & Exam No. 2 & \\
\hline 24 & Direct Heat and Mass Transfer & 13.1 to 13.2 \\
\hline 25 & Coolling Towers & 13.3 \\
\hline 26 & Heat Exchanger DesIgn 1 & 14.1 to 14.3 \\
\hline 27 & Heat Exchanger Design 2 & 14.4 to 14.6 \\
\hline 28 & Heat Exchanger Deslgn 3 & 14.7 \\
\hline 29 & Fleld Trlp to HVAC Company & \\
\hline 30 & $\begin{array}{l}\text { Review/ASHRAE Weeting } \\
\text { FINAL EXAM }\end{array}$ & \\
\hline
\end{tabular}

\footnotetext{
Text: Heoting, VentllatIng, and AIr Conditlonling: Analysls and Design, F. C. MCQulston and J. O. Parker, WIIey.

FINAL EXAM
} 


\section{TABLE 8. ME 437: Principles of Building Energy Analysis--Texas A\&M}

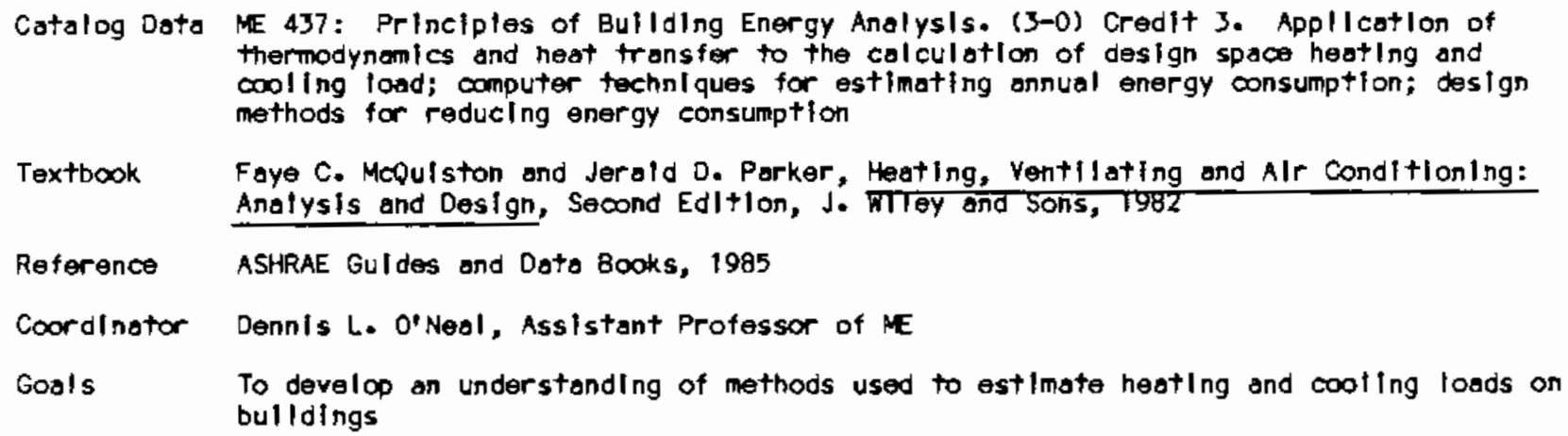

Textbook Faye C. MCQulston and Jerald D. Porker, Heating, Ventilating and Alr Conditionling: Arafysis and Design, Second EdItion, J. FlTey ard Sons, 1982

Reference ASHRAE Guldes and Dato Books, 1985

Coordinator Dennis L. O'Neol, Assistant Professor of ME

Goals To develop an understending of methods used to estimate heating and cooting loads on bulloings

1. Thermodynamics

Prerequistes by Tople

2. Fluid machanies

Toples

1. Molst air propertles and processes (2 classes)

2. Comfort and health (2 classes)

3. Heat transmission in bullding structures (4 classes)

4. Solar rodiation ( 3 closses)

5. Infiltration (2 classes)

6. Heating loads ( 3 classes)

7. Steady-state cooling load methods (4 classes)

8. Translent coolling load methods (3 classes)

9. Energy estimating methods ( 3 classes)

10. Exans (2 classes)

11. Fleld trlp/Professtonal meetings (2 classes)

Loboratory Projects

None

EstImoted ABET Category Content

Englneerling Sclence 1.5 credits or 508

Englneering Design 1.5 credits or $50 \%$

Energy Management." Student syllabi for the classes are presented in Tables 10, 11, 12, and 13. ME 661 details the various kinds of energy systems available or being developed. ME 662 concentrates primarily on the aspect of energy management in industry, ME 664 covers energy management in commercial buildings, and ME 664 indicates various applications of energy management. 
TABLE 9. ME 438: Energy Conservation in Industry and Commerce--Texas A\&M

\begin{tabular}{|c|c|c|}
\hline $\begin{array}{l}\text { Class } \\
\text { Perlod }\end{array}$ & $\begin{array}{c}\text { Reading } \\
\text { Assignment }\end{array}$ & Subject \\
\hline 1 & - & Introduction to industrlal and commerclal energy conservetion \\
\hline 2 & Chapter 1, pp. 1 to 13 & ImplementIng an energy conservation program; careers \\
\hline 3 & Chapter 2 & Industrlal and commercial energy systems; energy audit \\
\hline 4 & - & Walk-through audit \\
\hline 5 & Chapter 3 & Electricity and rate structures \\
\hline 6 & Chapter 3 & Fossli fuels \\
\hline 7 & Chapter 4 & Energy conservation economics \\
\hline 8 & Chapter 1, pp. 15-25 & Energy accounting \\
\hline 9 & Chapter 5 & Lighting systems \\
\hline 10 & Chapter 6 & HVAC systems \\
\hline 11 & Chapter 6 & Bullding envelope \\
\hline 12 & - & Hour Examlnation 1 \\
\hline 13 & - & Second law efflclency \\
\hline 14 & Chapter 7 & Fuels and combustion \\
\hline 15 & Chapter a & Combustion and bollers \\
\hline 16 & Chapter 8 & Bollers and other ffred systems \\
\hline 17 & Chapter 8 & Steem and condensate systams \\
\hline 18 & Chapter 9 & Waste heot recovery \\
\hline 19 & Chapter 8 & Cogeneration \\
\hline 20 & Chapter 8 & Cogeneration \\
\hline 21 & - & Hour Examination 2 \\
\hline 22 & -- & Electrical consideratlons \\
\hline 23 & - & Electric motors and circults \\
\hline 24 & Chapter 9 & Computer control systens \\
\hline 25 & Chapter 10 & Malntenance \\
\hline 26 & - & Hour Examlnation 3 \\
\hline 27 & Chapter 11 & Insulation \\
\hline 28 & Chapter 12 & Process efergy management \\
\hline 29 & Chapter 12 & Process anergy management \\
\hline 30 & - & Revien for final examlnation \\
\hline
\end{tabular}

Textbook: Energy Menagement, by Willlam J. Kennedy, Jr. and Wayne C. Turner, Prentice-Hal1, 1984. 
TABLE 10. ME 661: Energy Systems--Texas A\&M

1. Introduction

A. The retationship of energy consumption to stendard of tiving

B. History of energy consumption and future projections

C. Energy sources, prlces, and avellabillty

11. Fuel supplles

A. Natural gas

B. Petroleum

C. Cosl

1. Government policy and mining restrictions

2. Westerm coal supplies

3. Coal storage

4. Converting to coal

5. Cool gasification

5. Coal conversion

D. Electric utilities

111. Environmental conslderations

A. $\mathrm{SO}_{2}$ control

B. Particulate control

C. Scrubbers

D. NO control

E. Thermal pollution

F. Environmental constralnts on plant location

IV. FInanclat and other considerations

A. Capltal formation

B. Tox polficy

C. Occupational sofety - OSHA rules and regufations

D. Codes and standards

V. Nuclear power

A. Baslics of nuclear power

B. Nuclear power plants

C. Nuclear plant regulation

D. Delays in development

V1. Development of new concepts

A. Financing new concepts

B. Oll shale dovelopment

C. Waste utillzation

D. Integrated utility systems

E. Heating and Cooling distrlats

VII. Thermodynamics

A. Revlew of concepts

B. Second las limitations on energy conversion

VIII. Efflclent energy utiflization

A. Heating and cooling systems

B. Heat rejections systems

C. Solar energy

D. Integrated utllity systems

E. Energy conservation

1x. Speclal toples

A. Oll shale, far sands, geothermal

B. Polftics in the Mideast

C. Safety

D. Student presentations 
TABLE 11. ME 662: Energy Management in Industry--Texas A\&M

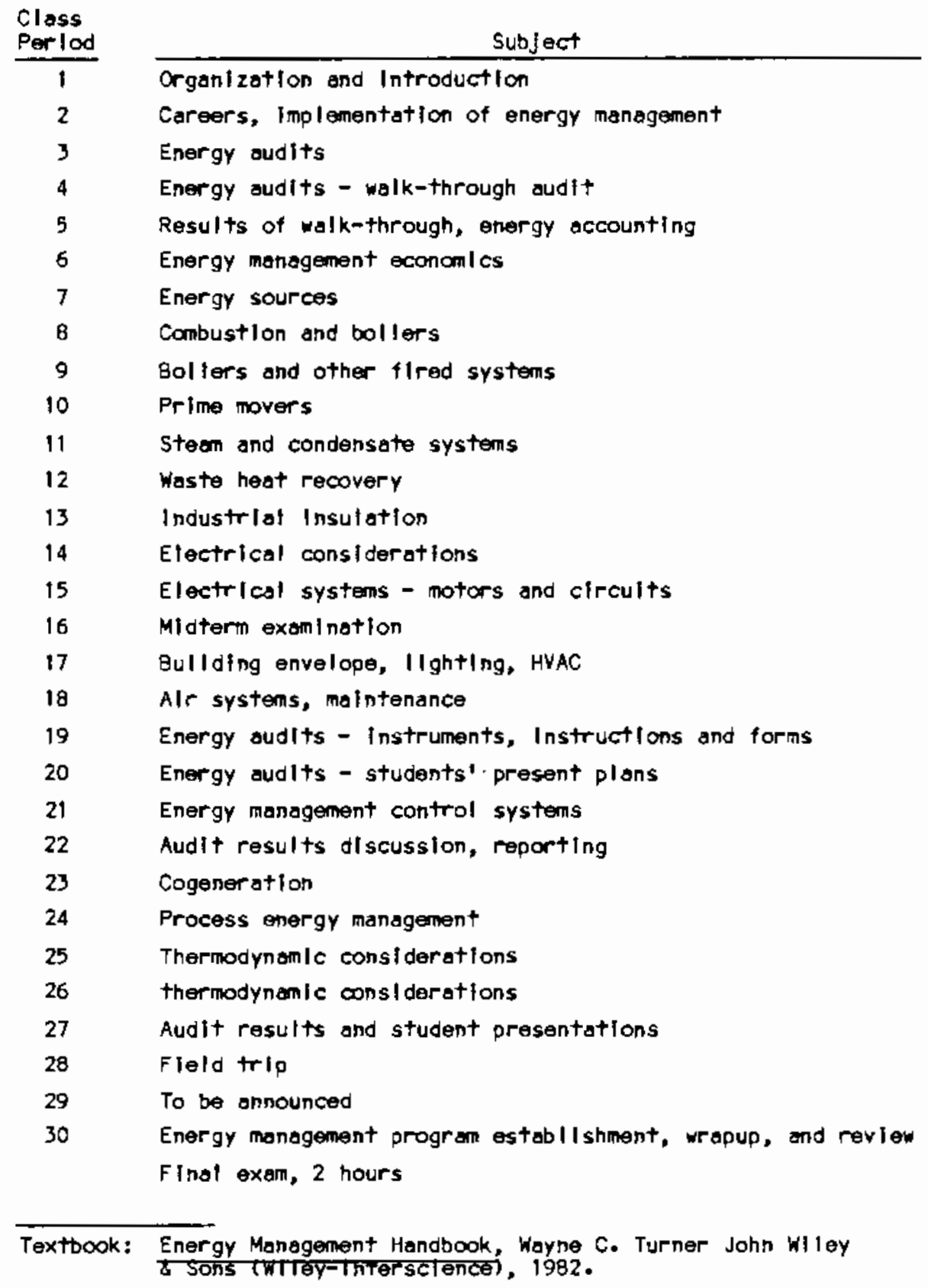


IABLE 12. ME 664: Energy Management in Commercial Buildings--Texas A\&M

QBJECTIVES: To famlifarize students with: a) energy-using equipment and systems in commerclal bulldings, b) ways to improve energy efflclency in this equipment, and c) energy economlcs procedures.

Class

Perlod

Tople

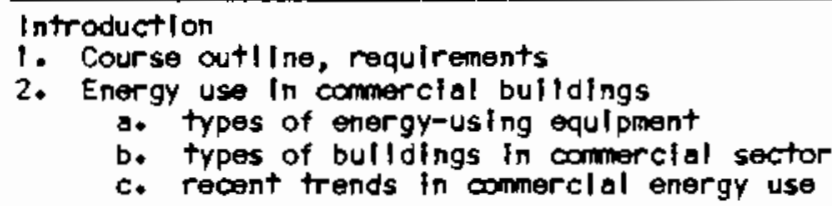

2 to 3 Energy Economles

1. Analysis of energy bill - energy, power, power factor

2. Economic analysls procedures

a. time value of money

b. simple payback

c. discounted payback

d. Ilfe-cycle costs

4 to 5 EstImatling Annual Energy Use/Demand

1. New bulldings: modeling energy use/comparisons

Messurement mothods

a. slngle meosurement nethods

b. bin method

c. hourly method

2. Audits in commerclal bulldings: audit procedures, what to look ot and for, and expected results

6 to $7 \quad$ Llghting Systems

1. Significance of Ilighting on energy use

2. Definitions of lighting terms (footcandle, lumen)

3. types of lights: efflcacy and appllcatlons, $\theta \cdot g *$, fluorescent, Incandescent, sodlum

4. New Ilighting technologles and their applicotions, e.g., photocelis, solidustate bollasts

$8 \quad$ DDC

Presentation by private compony in Dallas

9 to 10 Energy Managenent Sympos Iums

Attendance of commerclal-bullding-related poper sessions and seminars

$11 \quad$ Electrlc Motors

1. Applications of electric motors, e.g., fans, compressors,

2. Types of motors, a discussion of starting chorocteristies, efficiency, power factor, and part-load characterlistics

3. Typlcal economics of electric motors

12 to 15 Alr OIstrlbutlon Systems

1. Overview of systems and energy-using characterlstics including

a. single-zone

b. variable alr volume

c. reheat

d. dual duct

2. Psychrometrles revlew

3. Duct design

4. Fans, Including

a. types and characterlistics

b. applications: fan laws

c. energy use

5. Air flow measurement 
TABLE 12. (contd)

Class

Period

16 to 17

Tople

Project No. 1: Presentations

Topic: recent energy management appllcotions in commerclal bulfidings

Requirement: a ritten report and a 20-minute oral presentation sunwarizing 4 or more papers or articles all on the same theme $(e . g \cdot$, heat pump appllcatlons, retrofits)

IB to 19 Water Distribution Systems

1. Types of systems: 2-plpe, 3-plpe, and 4-plpe

2. System sizing and balancling

3. Pumps, including characterlstics and sizing

20 to 21 Refrigeration Plant

1. Chillers - slzes, typlcal performance

a. centrifugal

b. reciprocating

c. screw

d. absorption

2. Single package systems

22 to 23 Control Systems

1. Role of controls in energy management

2. Types of control strategles: on-off and proportional (integral and derlyative)

3. Typlcal translent performance of components

a. valves and dampers

b. heat exchangers

c. thermostats

4. Energy management control systems-types and applications

24 to 26 Energy Recovery Systems

1. Typlcal applicetions

1. Types of systems

a. ff fxed, rotating, etc.

b. heat recovery and enthalpy recovery

3. Colculating sizing, performance, and economles

27 to 28 Thermal storoge Systems

1. Typlcal appllcations

2. Types of systems. DIscussion of heating applicatlons and cooling applicatlons

3. Calculation of performence

29 to 30 Project No. 2 Presentations

Topic: Probably use DOE 2.1B to model a sImple commercial bullding. Evaluato prospective retroflt possibllitles.

REQUIREMENTS: Written report and 20- to 25-minute oral presentation 
TABLE 13. ME 665: Applications of Energy Management

1. Load Calculation Fundamentals

A. Design bullding loads

1. heoting load

2. coolling lood

B. Bullding energy analys \$s

1. Transfer function method

2. commonly used algorlthms

2. state-of-the-art programs

11. C. Development of a system energy model

11. Energy Audit Analys is

A. Steam generation and use

B. Process heatIng

1. design and control

2. heat recovery

C. HVAC

1. IIghting loods

2. comfort conditioning

3. ventilation requlrements

D. Prime mover energy consumption

1. pumps

2. tans

UNIVERSITY OF FLORIDA - INDUSTRIAL ENERGY MANAGEMENT COURSE

The University of Florida offers one course in industrial energy management. (a) Prerequisites include junior level standing and courses in physics, calculus, engineering economy, and thermodynamics. Topics covered in the course include:

- energy supply and demand

- the National Energy Act

- energy audits

- energy conservation and management

- alternative energy sources

- investment analysis

- the energy future.

(a) Dr. B. L. Capehart, Department of Industrial Engineering, University of Florida, provided information concerning this course. 
Application areas for this course include homes, institutions, businesses, Targe buildings, and industry. The emphasis is the appliance of energy conservation. Guest speakers from other departments and from industry give students the opportunity to hear "real world" energy applications. Previous guest speakers for the class have included lighting design consultants, utility energy conservation representatives from utilities, and a phosphate industry energy manager.

EIN 4321 presents both the current energy picture and the trends for the future. The following objectives are listed for the class:

- to enable the student to understand the basic energy picture and where the world is heading

- to enable the student to review basic energy-related sciences

- to enable the student to understand the methods of energy management in homes, institutions, businesses, large buildings, and industry

- to enable the student to understand the realistic potential of renewable energy sources by listening to speakers, researching, and formulating their own opinions

- to enable the student to develop an overall energy awareness and a conservation ethic.

A course outline is shown in Table 14. Grading in the course was done on the following basis:

- Exam No. 1 $20 \%$

- Exam No. 2 $25 \%$

- Exam No. 3 $25 \%$

- Audit report and case study $20 \%$

- Homework assignments $10 \%$ 


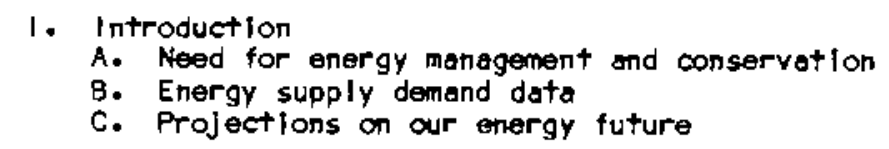

11. Energy Economles

A. Economic decision criteria

B. Energy prlcing structures

C. Energy-conservation Investment anelysis

III. Energy Audits

A. NECPA and residential conservation service

B. Schools and hospltals audit program

C. Industrial audits

1v. Energy conservation and use legistation

A. EPCA and ECPA

B. NEA 1978

1. Power PIant and Industrial Fuel Use Act

2. PURPA

3. Energy Tox Act

V. Energy Management Systems

A. Monltoring and control functions

B. LIghting, HVAC, demand leveling

C. Reseorch In optimum scheduling for cost minimizetion

vi. Other Tools

A. Lighting and llghting deslgn

B. Heating and cooling load calculations

C. Insulation cost and benefits

Vil. Waste Heat Recovery
A. Waste heat bollers
B. Cogeneration
C. Toppling and bottoming cycles
D. Total energy-system case study

Vill. Commerclal Energy Management

A. Energy use characteristics

B. Lighting, HVAC systems, boller effliclency

C. Cose studles-grocery store, fast food establishment

1X. inspection Tours

A. Natural gas I lquids plant

B. University heat plant

C. University energy management computer

D. UnIversity solar nesearch park

$x$. Guest Speakers

A. Lighting design consultant

B. Utility energy conservation representative

C. Phosphate Industry energy manager 
California State Polytechnic University at Pomona offers ME 306 "Energy Management."(a) The course covers the history of energy management, strategies used in efficient management, HVAC, lighting, electrical power, sources of energy, automation systems, sources of energy, economics, and energy and the environment. Tables 15 and 16 detail the course outline, outlines of the required texts and appendices, and a list of references used in the course.

TABLE 15. ME 306: Energy Management--California State Polytechnic University

\begin{tabular}{|c|c|}
\hline $\begin{array}{c}\text { Class } \\
\text { Sesston }\end{array}$ & Tople \\
\hline 1 & Introduction \\
\hline 2 & Past, Present and Future \\
\hline 3 & Strategies \\
\hline 4 & strategles \\
\hline 5 & Total Energy Manegenent \\
\hline 6 & TEM Surveys \\
\hline 7 & Thermodynamles \\
\hline B & Heat Transfer \\
\hline 9 & Bullding Structure and Systems \\
\hline 10 & Spectal Systems and Processes \\
\hline 11 & Heating and Ventllating \\
\hline 12 & Alr Conditioning Systems \\
\hline 13 & Survey of a Compus Bullding \\
\hline 14 & Refr I geration \\
\hline 15 & LIghting and Electrical Power \\
\hline 16 & Automation Systems \\
\hline 17 & Survey of a Campus Bufliding \\
\hline 18 & Energy Economies \\
\hline 19 & Sources of Energy \\
\hline 20 & Energy and the Environment \\
\hline
\end{tabular}

\begin{tabular}{|c|c|}
\hline ReadIng Assignment & Other Assignments \\
\hline None & None \\
\hline Chapters 1 and 2 & $S P-1$ and 2 \\
\hline Chapters 3 and 4 & $\mathrm{SP}-3$ \\
\hline Chepters 5 and 6 & $S P-4$ and 5 \\
\hline Chapter 7 & SP-6 \\
\hline Chapter 7 & SP-7 and 8 \\
\hline Chapter 8 & Audft Report No. 1 \\
\hline Chapter 9 & $S P-9,10$ and 11 \\
\hline Chapter 10 & $\mathrm{SP}-12$ \\
\hline Chopter 11 & $\mathrm{SP}-13$ and 14 \\
\hline Chapters 12 and 13 & Audit Report No. 2 \\
\hline Chapter 14 & $S P-15$ and 16 \\
\hline None & Update/Supp Report \\
\hline Chapter 15 & SP-17 through 25 \\
\hline Chapters 16 and 17 & Audit Report No. 3 \\
\hline Chapter 18 & Sp-26 through 35 \\
\hline None & $S P-36$ \\
\hline Chapter 19 & None \\
\hline Chapter 20 & Audft Report No. 4 \\
\hline Chapter 21 & Course Evaluation \\
\hline
\end{tabular}

Text: Readings for ME 306 , Energy Management.

(a) Course information was provided by Dr. Douglas Dowell, California State University, Pomona, California. 
TABLE 16. Text Contents--Readings for ME 306--California
State Polytechnic University

\begin{tabular}{|c|c|c|}
\hline Chapter & $T i+1 e$ & Poge \\
\hline 1 & Energy Management & $1-1$ \\
\hline 2 & Energy Data, Problems and Management & $2-1$ \\
\hline 3 & Past, Present and Future & $3-1$ \\
\hline 4 & Energy Strategles & $4-1$ \\
\hline 5 & Personal Strategles & $5-1$ \\
\hline 6 & Government Strategles & $6-1$ \\
\hline 7 & Total energy Management & $7-1$ \\
\hline 8 & Energy and Thermodynamies & $B-1$ \\
\hline 9 & Heat Transfer & $9-1$ \\
\hline 10 & Bullding Structure and Systems & $10-1$ \\
\hline 11 & Speclal Systens and Processes & $11-1$ \\
\hline 12 & Comfort Heoting Systems & $12-1$ \\
\hline 13 & Ventilation & $13-1$ \\
\hline 14 & Air-Conditionling Systems & $14-1$ \\
\hline 15 & Refrigeration Systems & $15-1$ \\
\hline 16 & Lighting Systems & $16-1$ \\
\hline 17 & Electrlcel Power & $17-1$ \\
\hline 18 & Energy Management Automatlon Systems & $18-1$ \\
\hline 19 & Energy Economics & $19-1$ \\
\hline 20 & Sources of Energy & $20-1$ \\
\hline 21 & Energy and the Environnent & $21-1$ \\
\hline- & Appendices & $A=1$ \\
\hline
\end{tabular}

\footnotetext{
Appendlces

1. Excerpt from the Californito Energy Commission, Energy Conservation Manual for New Residentlal Bulldings

2. Home Energy Manual

3. Excerpt from the Callfornla Energy Comission Energy Auditor Tralning Manual

4. Southern Cafifornfa Edison: If This Number is ToO High

5. Southern Callfornla Gas Company: Free Do-lt-Yourself Energy Survey Questionnaire

6. Son Diego Ges and Electrlc: LiHte Thlings Do County

7. Los Angeles Department of Water and Pover: OptImum Energy House

8. Southern Callfornile Edison: How to Beat the Heat

9. Southern Cafifornia Edison: Join the Conservation Generation

10. Shefl oll Company: Conservation Payback

11. Shell oll Company: The Conservation Bonus

12. Discount Foctors

13. UPW Factors Modifled for Energy Price Escalation

14. Dato and Control Polnts for Varlous HVAC Systems
} 


\section{TABLE 16. (contd)}

References

1. Calffornla Energy Comission. Aprit 1980. Energy Auditor Training Manual.

2. Callfornia Energy Combsion. Fall 1984. Energy Conservation Manual for New Residentlal Bulldings.

3. O'Bannon, Donoho and Hunt. 1977. Energy Conservation and Alternative Energy Curriculum. Californfa Energy Resources Conservaftó and Development Commsston.

4. Turner, Wayne. 1982. Energy Managenent Handbook. Wlley Interscience.

5. Kennedy and Turner. 1984. Energy Management. Prentlce Hall.

6. Smith. 1981. Energy Management Principles. Pergamon Press.

7. Gibbons and Chandler. 1981. Energy, The Conservation Revolution. Plenum Press.

B. Energy Graphlcs, 1983. Prentlce Hałt.

9. U.S. Department of Energy. Date? The Residentlal Energy Audit Manual. Falrmont Press.

10. Dorf. 1978. Energy Resources and Pollicy. Addlson Wesley.

11. Gibbons and Chandler. 1981. Energy, The Conservation Revolution. Plenum Press.

12. Energy Economles, Poltcy and Management. Fall 1982.

13. Energy Conservation with Comfort. 1979. Honeywell.

14. Total Energy Management. 1976. NECA, NEMA, USDOE and PGSE.

15. Watker. 1977. Energy, Optlons and Issues, U. C. Devis.

16. Providing for Energy Efflclency in Homes and Small Bulldings. 1980. U*S. Department of Energy.

17. Progress Bulletin. November 25, 1979. Pomona, Callfornila.

18. RIdgeway. Date? Energy Efflclent Communlty Planning. The J. G. Press.

19. The Fuel Shortage Contingency Plan Workshop. June 26, 1981. Orange County, Callfornla.

20. Energy Conservation, A Management Report for State and Local Governments. 1975. Publle Techiology, Inc.

21. Energy Management and Conservation. Date?

22. ? Refrigeration Data

23. Queston and Parker. Date? HVAC Analysis and Design. Wiley

24. Russell, Jim. 1985. Basic Refrlgeration. Southern Californfa EdIson.

25. Llbach, Nadine. June 1984. Evolution in Lighting. EPRI Journal.

26. Plugging Cogeneration into the GrId. July/August 1981. EPRI Journal.

27. Introduction to Automation Systems. December 1983. Southern Callfornia Edison Training Manual.

28. Handbook 132. Date? Natlonal Bureau of Standards.

29. Ruegg and Marshall. July 1981. "Economles of Bullding Deslgn." Solar Age.

30. Thomas. Date? Conservatlon, Its Promlses and Problems. University of New Hampshire.

31. Rouse and 5mith. Date? Energy, Resource, Slave, Pollutant. MacMIIlan.

32. Controls DIvision, Butler Manufacturing Company. January 1986. Facllities Management Systems. 


\section{COURSES AT LOUISIANA TECHNICAL UNIVERSITY}

Prerequisites for Mechanical Engineering 438 "Industrial Energy Conservation" include Chemical Engineering 321 or Mechanical Engineering 331. The course offered at Los Angeles Technical Institute stresses identification and analysis of energy conservation opportunities in the manufacturing and process industries. As a part of the course, each student visits an industrial plant, participates in the identification and analysis of energy conservation opportunities, and prepares a report.

A syllabus for the class is presented in Table 17. In order to share the knowledge gained from individual studies, each student is expected to present an oral report. (a)

The course covers the following areas:

- energy sources and rate structures

- combustion (analysis, fired equipment, controls)

- waste heat recovery

- steam systems

- electrical equipment (motors, power factor, demand control)

- compressed air systems

- insulation

- heating, ventilating, and air conditioning

- lighting

- cogeneration

- energy management systems

- energy conservation survey (energy usage analysis, plant survey, data gathering and measurements, analysis, and reporting).

(a) Course information was provided by Dr. James Lowther, Mechanical Engineering, Louisiana Tech. 
TABLE 17. ME 438: Industrial Energy Conservation--Louisiana Technical University

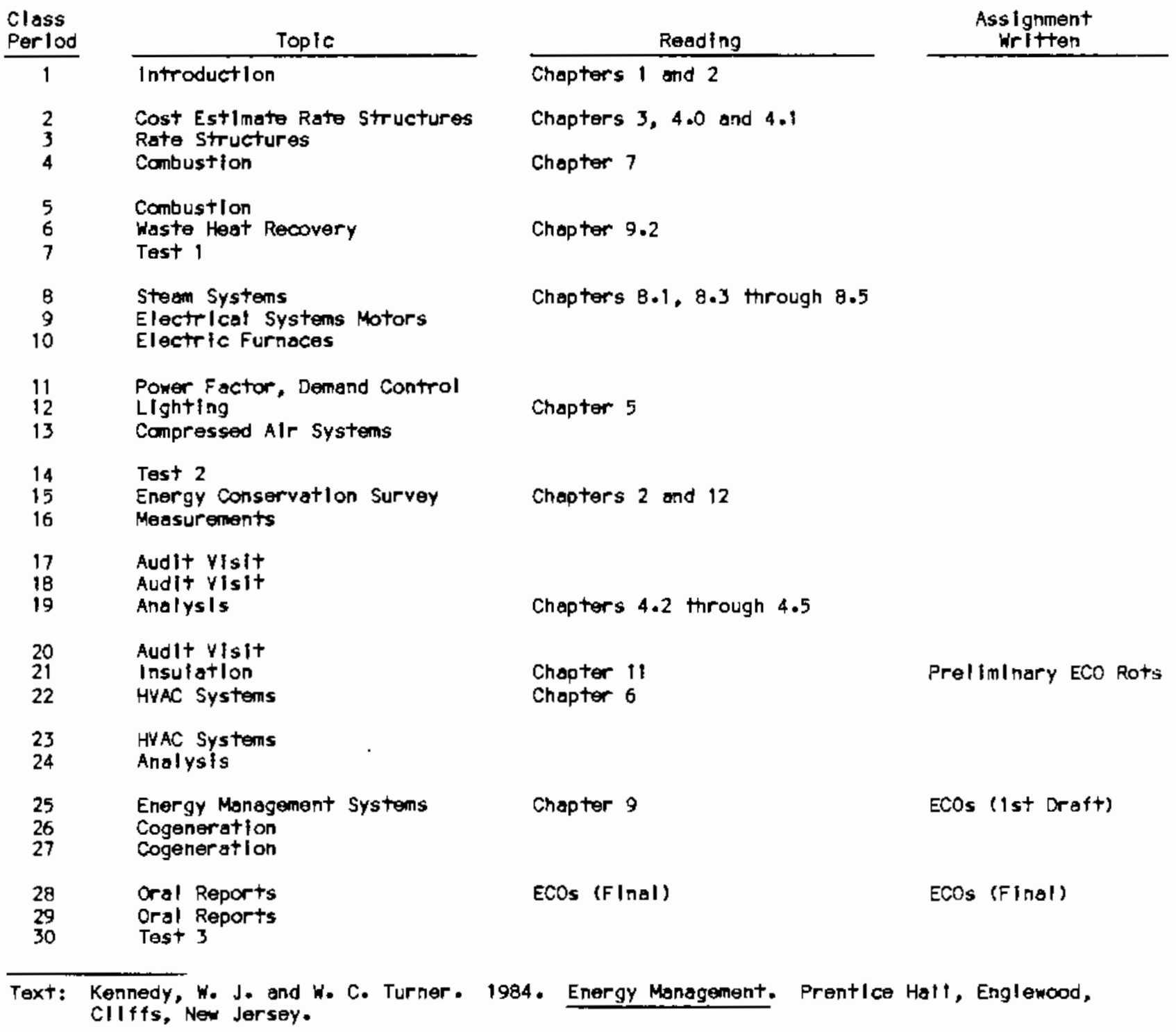




\section{COURSES AT THE UNIVERSITY OF KANSAS}

ME 729 "Introduction to Energy Management," a semester class, was designed to enable students to recognize and evaluate energy management opportunities in manufacturing plants. Students participate in four all-day energy audits and report on these. ME 612 "Heat Transfer" is a prerequisite for this class. (a)

Grading for the course was done on a point system. Each of the four field trips was weighted at 100 points for a total of 400 points. The one project report was weighted at 50 points. Table 18 details the course outline.

TABLE 18. ME 729: Introduction to Energy Management--University of Kansas

\begin{tabular}{|c|c|c|}
\hline Perlod & Tople & Text ReadIng \\
\hline 1 & Startup & \\
\hline 2 & Startup & \\
\hline 3 & $\begin{array}{l}\text { Lighting: Lomp choracteristics, efflcacy, replocement } \\
\text { Trequency }\end{array}$ & $\begin{array}{l}\text { Chapter 2, p. } 42 \\
\text { Chapter 5, pp. 90-109 }\end{array}$ \\
\hline 4 & $\begin{array}{l}\text { Lighting (Continued): Implementation costs, if fe-cycle costs, } \\
\text { Calculations }\end{array}$ & Chapter 12, pp. 231-240 \\
\hline 5 & Llghting (Continued): Sensors, audit procedure & \\
\hline 6 & $\begin{array}{l}\text { Inflltratlon: Theory, calculations, Implenentation costs, } \\
\text { addit procerdure }\end{array}$ & \\
\hline 7 & Infiltration (Continued) & \\
\hline 8 & $\begin{array}{l}\text { Domestlc Hot water: Reduce temperature, switch from } \\
\text { electiflc to gas hiet, calculatlons, oudit procedure }\end{array}$ & \\
\hline 9 & $\begin{array}{l}\text { Insulation: Types, temper ature ranges, conductivities, } \\
\text { costs, optimal thickness, iliquid surface energy loss, } \\
\text { operating temperature reduction, audit procedure. } \\
\text { Audt Fleid Trip }\end{array}$ & $\begin{array}{l}\text { Chapter 8, p. } 161 \\
\text { Chapter if }\end{array}$ \\
\hline 10 & $\begin{array}{l}\text { Compressed Alr: Compressor heat recovery, outslide air, } \\
\text { pressure reduction, schedulling and laad control, fllters, } \\
\text { air-leaks, audit procedure. ECos and audit report preparation }\end{array}$ & \\
\hline 11 & Compressed Alr (ContInued) & \\
\hline 12 & $\begin{array}{l}\text { Cambustion Equipment: Bol lers and furnaces, flue gas analy- } \\
\text { sis, olr-ful ratio control, stack dempers, turbulators, } \\
\text { stack heat recovery, preheat combustion alr, audlt procedure. } \\
\text { ECos and audft report preparatlon }\end{array}$ & $\begin{array}{l}\text { Chapter } 7 \\
\text { Chapter } 8\end{array}$ \\
\hline 13 & Combustion Equipment (ContInued) & \\
\hline
\end{tabular}

(a) Dr. Louis Burmeister, Department of Mechanical Engineering, University of Kansas, provided the course information. 
TABLE 18. (contd)

\begin{tabular}{|c|c|c|}
\hline Perlod & Tople & Text ReadIng \\
\hline 14 & $\begin{array}{l}\text { Bollers: Blowdown control and heat recovery, condensate } \\
\text { returh, preheat makeup and feed water, water treatment, } \\
\text { steen traps, steam leaks, boller and steem I Ine Insulation, } \\
\text { audlt procedure. Audit Fleld Trip }\end{array}$ & \\
\hline 15 & Bollers (ContInued): ECOs and audit report preparotion & \\
\hline 16 & Bolters (ContInued) & \\
\hline 17 & $\begin{array}{l}\text { Synthetlc Lubriconts: Types, cost, eppll cottons, audit pro- } \\
\text { cedure. Fans: fan aws, verlable speed control, ventllation } \\
\text { time and Pate reduction, point booths }\end{array}$ & Chapter 6, p. 124 \\
\hline 18 & SynthetIc Lubricants (Contl nued): & \\
\hline 19 & $\begin{array}{l}\text { Exhaust Heat Recovery: Goses, liqulds, cost } \\
\text { Afr Cleaners: ECOs and audit report preparation }\end{array}$ & $\begin{array}{r}\text { Chapter 8, pp. } 165-168 \\
\text { Chapter } 12, \quad p p \cdot 227-23 \text {; } \\
\text { and } 240-241\end{array}$ \\
\hline 20 & Atr Cleeners (Continued): & \\
\hline 21 & Congeneration & $\begin{array}{l}\text { Chapter 8, pp. } 172-175 \\
\text { Chapter 3, p. } 67\end{array}$ \\
\hline 22 & Cogener at Ion (Continued) & \\
\hline 23 & $\begin{array}{l}\text { Utility Data: Plots, information from U-Dato, examples, } \\
\text { quick calculations and formulas }\end{array}$ & \\
\hline 24 & $\begin{array}{l}\text { utility Blits: Structure, demand cost and its control, } \\
\text { power factor correction and cost }\end{array}$ & $\begin{array}{l}\text { Chapter } 3 \\
\text { Chapter } 4\end{array}$ \\
\hline 25 & $\begin{array}{l}\text { Thermostat Control: Weather data, bullding toed and } \\
\text { energy colculditobs, heatling and coolling degree hours, } \\
\text { setup and setback }\end{array}$ & Chapter 6 \\
\hline 26 & $\begin{array}{l}\text { Thermostat Control (Continued): Destratificatlon, } \\
\text { Caniputer progialn, audit procedure. Audit Fleld Trip }\end{array}$ & \\
\hline 27 & $\begin{array}{l}\text { Thermostat Control (Continued): ECOs and audit report } \\
\text { preparation }\end{array}$ & \\
\hline 28 & $\begin{array}{l}\text { HVAC Equlpment: Chlllers, controls, economlzers, dirty } \\
\text { Colls, alr-handler cablinet leakoge }\end{array}$ & \\
\hline 29 & HYAC Equlpment (ContInued) & \\
\hline 30 & ECOs and audit report preparation & \\
\hline 31 & Alternatlve Energy Sources: Wood, solar, waste & Chapter 13 \\
\hline 32 & Alternative Energy Sources (ContInued): Completed Audlt Report & \\
\hline 33 & ECOs and audit report preparation & \\
\hline 34 & $\begin{array}{l}\text { Process Energy Conservation Opportunities, Control Systems } \\
\text { Matntenance }\end{array}$ & Chapters 9, 10 \\
\hline 35 & Conti nued & \\
\hline 36 & Utll1ty Data Reduction: Example of computer program use & \\
\hline 37 & Congeneration & \\
\hline
\end{tabular}


TABLE 18. (contd)

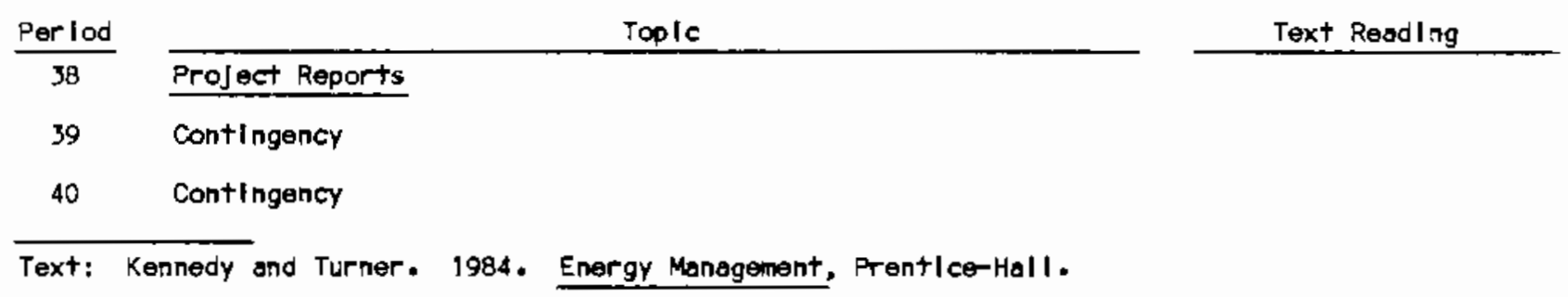


UNIVERSITY OF UTAH-INOUSTRIAL ENERGY MANAGEMENT

The University of Utah offers Industrial Engineering 579 "Energy Management." Students must have previously completed courses in chemistry, thermodynamics, and engineering economy. (a)

An energy audit, estimation of cost savings, cash flow analyses, examination of industrial energy systems, waste heat recovery, and boiler efficiency comprise the major topics covered in this class.

An outline of the course and the topics covered during each class period are shown in Table 19. Three tests, homework assignments, and an energy audit. have all been weighted equally in grading the class.

When students have successfully completed Industrial Engineering 579, they should be able to perform the following:

1. Do a thorough energy audit of an industrial facility, complete with a report of the findings and of possible cost savings or production improvements, in a form that is technically correct and easily understood.

2. Estimate the cost savings possible from these measures: inside and outdoor relamping, boiler combustion improvements, pipe insulation, waste heat recovery, HVAC system improvements, rescheduling, motor rewinding, and maintenance improvements.

3. Perform a technically correct after-tax, after-inflation discounted cash flow analysis of a proposed energy management project.

4. Develop, initiate, and monitor a maintenance improvement program intended to reduce energy costs.

5. Describe techniques for examining each of these systems: lighting, HVAC, electrical, boiler and steam distribution, hot water, compressed air distribution, envelope, and general industrial process.

6. Perform a heat balance for use in determining potential for waste heat recovery and process improvement.

(a) Dr. W. J. Kennedy, University of Utah, Industrial Engineering Department, provided the information on IE 579. 


\title{
TABLE 19. Industrial Engineering 579--University of Utah
}

\author{
Class \\ Session \\ The energy audit process. Analysis, Action, Monitoring. The report format: \\ introduction, graphics, methodologles, Electricity, and natural gas costs. Power and \\ lood foctors. Estimating first-yeor cost sovings. Problems: Numbers 1 and 2 \\ 2 Weighing costs versus benef1ts. Simple payback. Engl neerIng economy techniques with \\ Inflation and taxes. The effect of ACRS. Problems 3 and 4. \\ 3 The major systens and how to evaluate them. Problems 5 and 6 \\ 4 One hour test. Estimeting first-year cost savings fram various Improvements: \\ lightIng, boller Improvements, waste heat recovery, reschedulling, motor rewlinding. \\ Problems 7 and 8 \\ 5 Lighting systens. Klnds of lamps. Desirable lighting levels, Indoor and outdoor \\ Ilghtling. Color rendition, maintenance, the building envelope, physical and \\ psychologlcol foctors. Problems 9 and 10 \\ 6 Energy audit of an Industrial focility. Assignment: Energy oudlt report by teoms. \\ 7 HVAC systems. Kinds of HVAC systems, controls, estimoting heating ond cooling loods, \\ energy Improvenents. Problems 11 and 12 \\ 8 Bollers, Industrlat processes, and flue gas anolysis. Estimating efficlency from flue \\ gos onolysis. Problems 13 and 14 \\ 9 One-hour test on moterial. The steam distribution system. Problems 15 and 16 \\ 10 The heat balance as an onalytical tool. Colculoting Inputs and outputs, flnding \\ improvements, presenting results. Problems 17 and 18 \\ 11 Insulotion and woste heat recovery, developing and maintenance program. Problems 19 \\ and 20 \\ 12 Deslgning, inltlotIng, and managlng an energy management program \\ 13 Final examinotion. Comprehensive, 3 hours
}

Text: Turner, Wayne et al. 1982. Energy Managenent Handbook, Wlley/lntersclence, Ney York.

7. Analyze the composition of flue gas coming from a fuel with known proximate analysis in order to determine boiler efficiency. 
UNIVERSITY OF CINCINNATI --ENERGY MANAGEMENT/AUDITING CURRICULUM

The University of Cincinnati offers a certificate in Energy Management/Auditing Technology for students who have already earned a bachelor's degree or who are enrolled and actively pursuing a bachelor's degree. Requirements, a description of the technical core and three course syllabuses are shown in Tables 20 to 23 . (a)

(a) Information on the Energy Management/Auditing Technology program at the University of Cincinnati was provided by University College, Mathematics and Applied Sciences Department, Cincinnati, Ohio 45221. 


\title{
TABLE 20. Energy Management/Auditing Technology--University of Cincinnati
}

\author{
Technical Core
}

\section{REQU IREMENTS}

5tudents must take a minimum of twenty-seven (27) quarter credft hours of courses from the Energy Management/Audting Technology core of courses. The speciflic program for each student wlll be developed In consultation with the Program Coordlnator. An assumption of the program is that students from the College of Engl neering shall have different educational needs and interests than students from the College of Buslness AdmInIstratlon or the College of Design, Architecture and Art, etc. A maximum of three (3) quarter credit hours in the program may be awarded as advanced standing for courses taken outside of the University College.

See opproved core courses.

17-241-191 Energy Resource Technology. General overvlew of world, national, and reglonal energy situation and Its Implication for enterprise or institutional management. Discussion of present and future utllization for varlous energy sources wlll be feotured. $6 \mathrm{ug} / \mathrm{Cr}$

17-241-184 Electrical Energy Systems. Comporative study of electrlcal power distribution and area Illumination systems for commerclal, Institutional, and Industrlal facilities. Discussion of varlous system design concepts lll be emphaslzed. $6 \mathrm{ug} / \mathrm{cr}$

17-241-174 Mechenlcal Energy Systems. Comporative study of heating, ventilating, and alr conditloning systems for commerclal, Institutlonal, and industrial facilfties. Discussion of varlous system design concepts ill be empheslzed. $6 \mathrm{ug} / \mathrm{cr}$

17-241-271 Energy Systems Laboratory. Energy analysis presentation; correct use of arafting equipment In producling clear, preclse, and attractlve drawings. (6 contect hours) $3 \mathrm{ug} / \mathrm{cr}$

17-241-272 Independent Study in Energy Managenent. IndIvidual research and work for students related to career development in Energy Managenent/Auditing Technology. $3 \mathrm{ug} / \mathrm{cr}$

17-24i-284 Sol or Energy Systems. Comparative study of the application of active and passive soler energy systems to residential and commerclal structures. Discussion of various system desIgn concepts 11 ll be featured. $6 \mathrm{ug} / \mathrm{\sigma}$

17-241-273 Energy Auditing Procedures. Methods of conducting energy use surveys in commercial, institutional, and industrial facliltles. Proctlcal experiments in meosuring building energy consumption and distribution will be performed. Use of energy metering and instrumentation will be demonstrated. $6 \mathrm{ug} / \mathrm{cr}$

17-445-204 Data Processing for Energy Manegement 1, 11, 111. Introductlon to computers and com205 puter systems, numeric boses used In computers, flowcharting, programing using BASiC, 206 FORTRAN, and COBOL. To be taken sequentially or with permIssion of instructor. $3 \mathrm{ug} / \mathrm{Cr}$ 


\section{TABLE 21. Mechanica1 Energy Systems--University of Cincinnati}

Course No. 17-241-174

Course Description: A comparative study of heating, ventllation, and air-conditionling systems foi commerctal, Tnsfifutional, and Industrfal facllitles

The course will stort with the basic concepts of heating, ventilating, and alr-conditioning

systems. The terms used to describe these systems will be alscussed. Basle concepts of heat galn and heat foss colculations ill be presented and problems in the calculation of these concepts wlll be developed and problems assigned.

Varlous types of heating systems will be dlscussed and methods of heat distrlbution. Alrconditioning systems will be studied Including refilgerotlon. Concepts on comfort heotling and cooling using various types of temperatures vill be learned.

I deas and concepts of energy management of these varlous systems will be presented. Course Evaluatlon:

The following criteria will be used in determining final grades for this course:

$\begin{array}{cr}\text { Assignnents } 4 \text { e } 50 & 200 \text { polnts } \\ \text { Mid-term exam } & 300 \text { polnts } \\ \text { FInal exam } & 500 \text { polnts } \\ \text { Total } & 1000 \text { points } \\ \text { Course Outilne } & \end{array}$

\begin{tabular}{|c|c|c|}
\hline \multicolumn{3}{|l|}{ Class } \\
\hline Session & Tople & Ass I gnment \\
\hline $\begin{array}{l}1 \\
2\end{array}$ & $\begin{array}{l}\text { Introductlon and General D1scussion } \\
\text { Environmental Comfort }\end{array}$ & $\overline{4.1}$ to 4.12 \\
\hline $\begin{array}{l}3 \\
4\end{array}$ & $\begin{array}{l}\text { Heating Losses } \\
\text { The Arkansas Story }\end{array}$ & $\begin{array}{l}4.13 \text { to } 4.19 \\
4.23\end{array}$ \\
\hline $\begin{array}{l}5 \\
6\end{array}$ & $\begin{array}{l}\text { Heat Gains } \\
\text { Heating Systems }\end{array}$ & $\begin{array}{l}4.24 \text { to } 4.27 \\
5.1 \text { to } 5.3\end{array}$ \\
\hline $\begin{array}{l}7 \\
8\end{array}$ & $\begin{array}{l}\text { Herm Alr Heating } \\
\text { Hot Water, Steam and Central Heating } \\
\text { Systems }\end{array}$ & $\begin{array}{l}5.4 \text { to } 5.6,5.9 \\
5.7 \text { to } 5.8\end{array}$ \\
\hline $\begin{array}{r}9 \\
10\end{array}$ & $\begin{array}{l}\text { Coolling Systens } \\
\text { Heat Pumps }\end{array}$ & $\begin{array}{l}5.10 \text { to } 5.13 \\
5.14 \text { to } 5.16\end{array}$ \\
\hline $\begin{array}{l}11 \\
12\end{array}$ & $\begin{array}{l}\text { Mid-Term } \\
\text { Ventifation }\end{array}$ & 5.17 to 5.18 \\
\hline 13 & $\begin{array}{l}\text { Termina! Reheat Systems } \\
\text { Varfable Air Yolume Systems }\end{array}$ & 5.17 \\
\hline $\begin{array}{l}15 \\
16\end{array}$ & $\begin{array}{l}\text { Environmental Pianning } \\
\text { Climate Control Systems }\end{array}$ & $\begin{array}{l}6.1,6.8 \\
7.1 \text { to } 7.6\end{array}$ \\
\hline $\begin{array}{l}17 \\
18\end{array}$ & $\begin{array}{l}\text { Ali-Electric Systems } \\
\text { Solar Energy and Energy Conservation }\end{array}$ & $\begin{array}{l}7.9 \\
8.1 \text { to } 8.6\end{array}$ \\
\hline $\begin{array}{l}19 \\
20\end{array}$ & $\begin{array}{l}\text { Solar Heat Pump } \\
\text { Energy Conservation in Design and } \\
\text { Operation of Mechenlcal Systems }\end{array}$ & $\begin{array}{l}8.6 \\
8.10\end{array}$ \\
\hline
\end{tabular}

Text: McGulness, W. J., B. Stoln, and John S. Reynolds. Mechanical and Electrical Equlpment for Bulldings.

in addition to the above reading ossigments starting with the third and every other week thereafter, a problem 111 be assigned covering materlal that has been discussed In prevlous class sesslons. The problems will be due one weok after they are ossigned. 
TABLE 22. Electrical Energy Systems--Course No. - 17-241-184--
University of Cincinnati Course outline

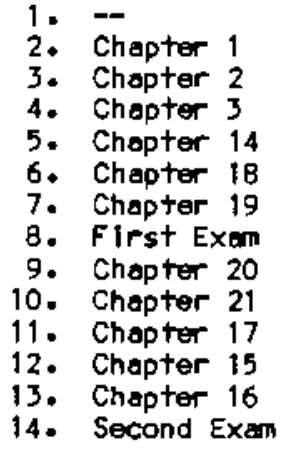

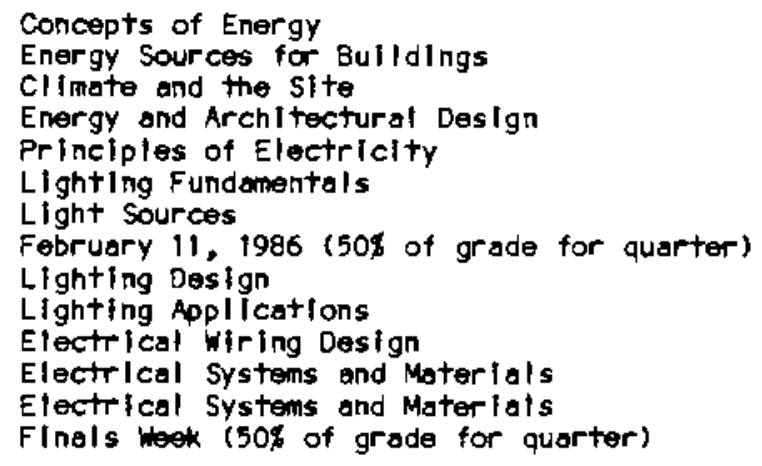

Text: McGulness, W. J., B. Steln, and John S. Reynolds. Mochanlcal and Electrlcal Equlpment for Bulldings.

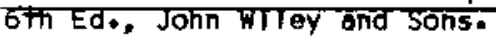

TABLE 23. Energy Resource Technology--Course No. - 17-241-191-University of Cincinnati

Textbook--None (Exams illt be based solely on materlals covered in lectures)

Exams--Closed book and no reference to lecture notes

Attendance-No speciffic penalties for missed classes

Course Outline

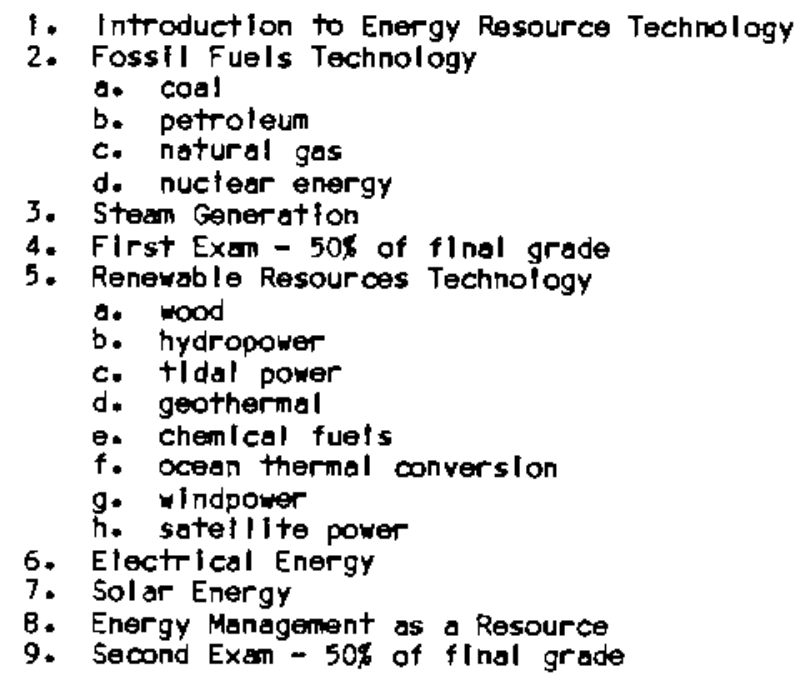


$d$

$\checkmark$

. 
CONTINUING EDUCATION COURSES

Several universities and colleges of fer energy management courses through their continuing education programs. These courses are often aimed at two distinct groups of individuals. One type of course is specifically directed toward the practicing professional in such disciplines as engineering, architecture, or physical science.

Another type of course trains high school graduates for entry-level positions with constructions, engineering, and architectural firms.

VIRGINIA POLYTECHNIC INSTITUTE AND STATE UNIVERSITY

Virginia Polytechnic institute and State University offers an Energy Management Diploma Program with continuing education (CE) credit. The four courses offered in this program are 1) EMl Organized approach to Managing Energy, 2) EM2 Developing a Cost-Effective Energy Project Inventory, 3) EM3 Energy Systems, and 4) EM4 Energy Design and Analysis. A detailed outline of course topics is given in Table 24 . (a)

(a) Information from Virginia Polytechnic Institute and State University was provided by Dr.W.H. Mashburn, Department of Mechanical Engineering, Virginia Polytechnic Institute and State University, Blacksburg, Virginia 24061 . 


\section{TABLE 24. Energy Management Diploma Program--Virginia Polytechnic Institute}

and State University

EM1 OrganIzed Approach to Managing Energy

Steps In Developling an Energy Management Program

a. sltuation reporting

b. organization

c. budget

d. audits

e economic analysis

f. selling the program

g. using consultants

h. educatlonal goals

i. strategle planning

Group Dynamics

a. IdentIfylng barrlers

b. workshop problem solving

Proflle of a New Corporate Program

a. organlzation

b. strategy

c. reporting

d. successful projects

EM Computer Selection Process
a. deflning needs
b. vendor selection
c. Installation
d. follow-up

Personet Computer for Reporting

a. spread sheet

b. flle systems

c. ward processing

d. hands-on experlence

Energy Strateglc Planning

o. components of a strategle plan

b. a successful corporate progrem

c. developling key issues - workshop

A Corporate TunIng-Operatlons-Maintenance Program

a. Identifying TOM Opportunitles

b. coordinating with energy surveys

c. economlcs of TON

Orgenization and Implementation of EM
a. basic organization
b. role of the plant
c. energy coordi nator
d. successful projects

utility Monitoring and Reporting

a. evolution of MRS

b. establishing and justifying the MRS

c. practical examples

Information Sources

a. publications

b. associations

c. people

Round Roblin Workshops

a. successfut projects

b. probtem solutions
EM2 Developing a Cost-Effective Energy ProJect Tतventory

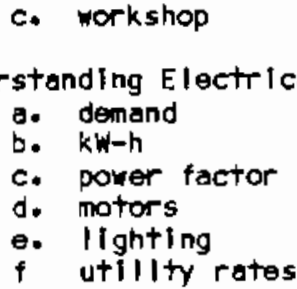

b. $k w-h$

c. power factor

d. motors

e. II ghting

f utillty rates

Utillty Load Management

a. economle dispatching

b. load management

c. hands-on simulator

Energy Audits

a. types

b. tean selection

c. climatic data

d. energy equations

$\theta$. energy index

Industrlal Audit Process

a. consulting arrengement

b. case history

Industrlal Audft

a. case history

Walk-Through Audit

o. audit of local Industrlaf plant

Economlc Evaluation

a. time value of money

b. paybeck return on Investment

c. Iffe-cycle costing

d. Internal rate of return

Workshop

o. preparation of audit report 


\section{TABLE 24. (contd)}

EM 3 Energy Systems

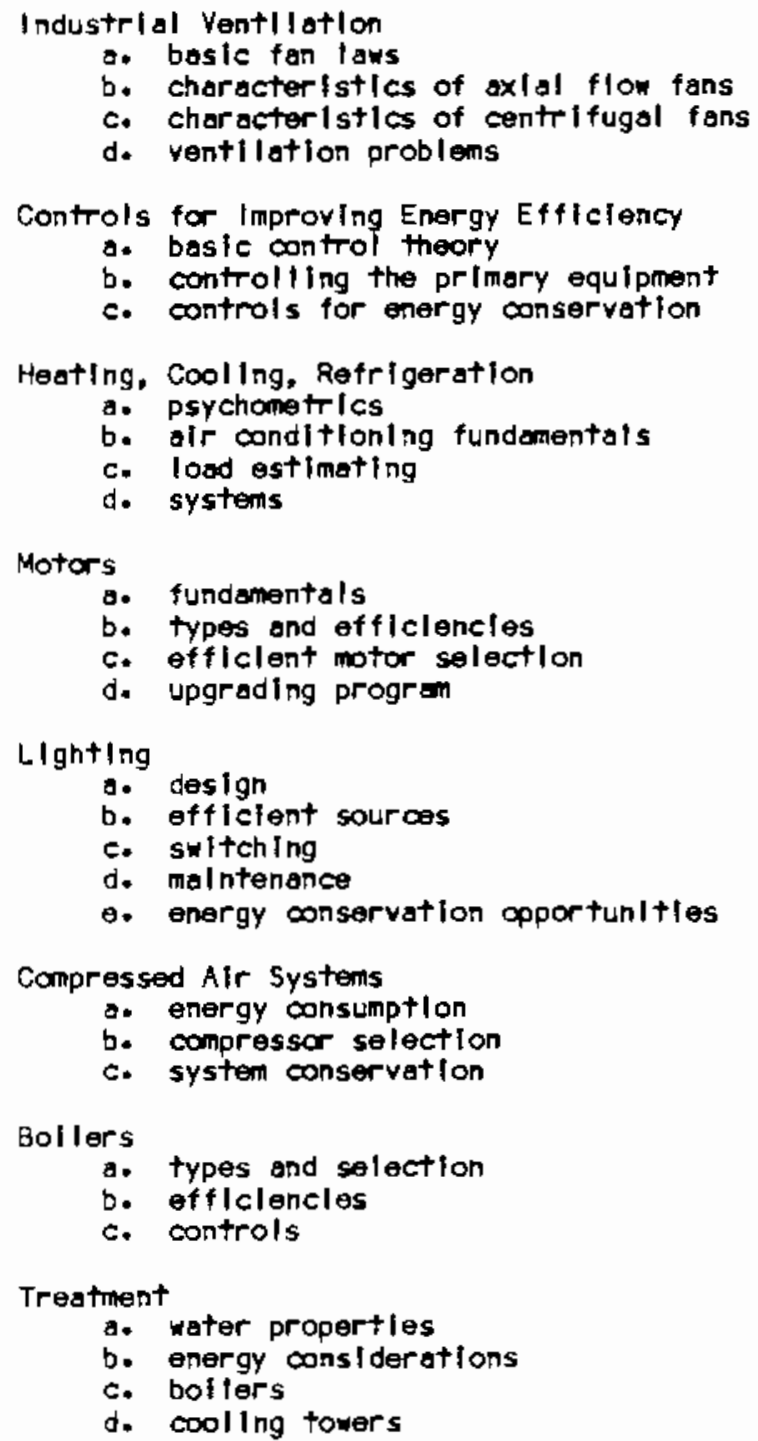

EM4 Energy Design and Analysis

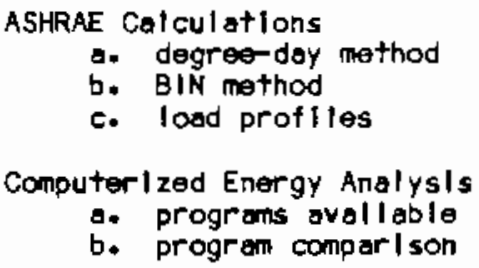

a* discussion of successful projects 
ENERGY MANAGEMENT SERIES - UNIVERSITY OF WISCONSIN

The College of Engineering at the University of Wisconsin-Madison has developed a series of four one-week courses. An Energy Management Diploma is available to qualified individuals who complete all four courses. Instructors include practicing energy managers, management consultants, and engineers. Participants earn continuing education units (CEU).

Courses are presented in a workshop format and are limited to no more than 30 students. Participants are encouraged to share work experiences that relate to course topics.

Energy Management Diploma candidates are required to have professiona? registration or a B.S. degree in engineering, architecture, or a physical science. Individuals who cannot meet the prerequisites but who have previous energy or engineering experience may inquire about their eligibility. (a) Previous engineering or management experience is especially helpful.

The University of Wisconsin describes these courses to students in their "Energy Management Series" brochure as follows:

Role of the Energy Manager (EM1) Effective energy managers in business and industry will present their keys to success. You will discover how you can reduce your firm's energy usage indices by 50 percent within a few years. Plan to study energy management program organization, management strategies, and specific tools for obtaining reliable, affordable energy supplies and efficient energy use in your facility.

This five-day course will teach you how to:

- Identify your organization's critical needs

- Organize a successful energy management program

- Identify barriers to effective energy management programs and develop solutions

- Utilize methods for working with groups and committees

- Incorporate energy into your strategic planning process

Data Gathering and Analysis (EM2) This course will help you develop an organized approach to energy data gathering and analysis

(a) This information was provided by Dr. Charles E. Dorgan, Department of Engineering and Professional Development, University of Wisconsin, Madison, Wisconsin 53706 . 
in your facility. You will learn how to use a key energy management tool--a thorough and efficient walk-through energy audit. You will analyze energy use and identify measures to conserve energy. In addition, you will evaluate the different sources of energy use information--in-house technical personnel, consultants and utility companies, studying the strengths and weaknesses of each and determining the best source of information for your facility.

Study of the following will help ensure good energy calculation and economic analysis:

- What to include in effective energy audit reports

- How much time to budget

- What auditor experience is necessary

- What procedures and calculations to use

- What instruments and measurements are useful

- How to determine or evaluate energy savings estimates

- How to calculate economic benefits

Building Energy Systems (EM3) Using sound energy management practices, you can obtain a 35-50 percent reduction in energy use for existing buildings. New buildings, properly designed, may consume only 25 percent of the energy required by existing buildings. In this course you will learn how your building and energy systems operate, how to analyze present system efficiencies, what improvements are possible and what gimmicks to avoid. Concepts apply to individual buildings, complexes and nonprocess industrial applications.

This five-day course will cover building envelope characteristics and energy-using systems. Topics include:

- Energy system operating principles

- Energy efficiency of typical existing systems

- Operation and control strategies for optimum efficiency

- Recommended efficiency-improving retrofits

- Energy-efficient systems and components for replacement and new construction

Industrial Energy Systems (EM4) Successful industrial energy managers have cut energy indices by 25 percent or more. This course will provide methods to help you develop an appropriate energy index for measuring performance and controlling energy costs. You will review the basics of process energy analysis and compare theoretical, potential, and actual performance of industrial energy systems. Your learning will include the latest heat recovery technology, combustion equipment, energy efficient electric motors and variable speed drives. Plan to work with other energy managers in solving typical industrial energy problems. 
Topies for this course will include:

- Energy management performance analysis and forecasting

- Process energy analysis techniques

- Energy efficiencies of commonly used systems

- Optimization of process and non-process operation and control

- Cost-effective retrofits

- Latest technology for waste heat utilization

- Energy-efficient designs, systems, and components for replacement and new construction

- Methods for analyzing potential savings

Individuals completing all four courses may take an Energy Management Diploma examination. In most cases, participating individuals can take this exam where they work. Individuals who have other energy responsibilities may wish to consider other courses of fered at the University of Wisconsin - Energy Audit Programs, Air Conditioning Design, and Alternative Energy Systems.

\section{ENERGY MANAGEMENT/AUDITING TECHNOLOGY - UNIVERSITY OF CINCINNATI}

The University of Cincinnati has developed the Energy Management/Auditing Technology program, which teaches students basic skills necessary for entrylevel positions in construction, engineering, and architectural firms. This program is one of only five such programs in the nation offering a complete associate degree curriculum. The program was designed to develop engineering technicians with specific vocational skills, including

- the ability to draft engineering drawings

- the ability to measure energy consumption and distribution in a variety of buildings

- capability to assist in designing energy-efficient mechanical and electrical systems

- a knowledge of various detailed energy auditing procedures.

An energy management laboratory, containing the latest equipment and instrumentation, provides students with practical experience.

High school graduates, or those who have completed the General Education Development (GED) test, may enter the course. Requirements for successful completion of this program are detailed in Table 25. 


\section{TABLE 25. Certificate in Energy Management/Auditing Technology University of Cincinnati}

Program A. This progran Is offered for students who have a high school diplona but do not plan to Eontinue on and earn an assoclate degree or hlgher degree. However, all courses requlred for this certiflcote are also required in the associlate degree progrem in Energy Management/Auditing Technology. If a student would later decide to earn the assoclate degree he/she would normally expect to be able to complete those requlrements by taking one additional full year of course work.

1.

$$
\begin{array}{cl}
\text { 17-241-184 } & \text { Electricol Energy Systems } \\
17-241-174 & \text { Mechanlcal Energy Systems } \\
17-241-271 & \text { Energy Systens Laboratory } \\
17-241-272 & \text { Independent Study in Energy } \\
17-241-273 & \text { Energy Auditing Procedures } \\
& \text { or } \\
17-241-284 & \text { Solor Energy Systems }
\end{array}
$$$$
\text { Technical Core Requlrements }
$$$$
\text { 17-241-212 Independent Study in Energy Manogement }
$$

11. Related Studles Requirements

$$
\begin{aligned}
& \text { 17-241-101, 102, } 103 \text { Princlples of Economics 1, 11, 111 } \\
& \text { or } \\
& \text { 17-025-101, 102, } 103 \text { Elementary Math Analysis 1, 11, 111 } \\
& \text { or } \\
& \text { 17-025-201, 202, } 203 \text { Calculus and Analytic Geometry 1, 11, 111 }
\end{aligned}
$$

III. General studies Requirements

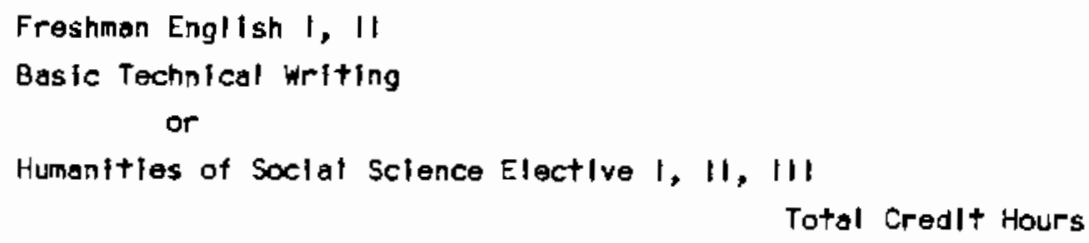


ANNOTATED BIBLIOGRAPHY

Ref .

No.

1. Kennedy, J., Jr. and W. C. Turner. 1984. Energy Management. Prentice Ha11, Englewood Cliffs, New Jersey.

Written specifically as a textbook for college courses in energy management organizations the text book discusses, energy auditing, rate structures, lighting, HVAC, combustion, and many other topics. The text contains worked-out examples as well as homework problems at the end of each chapter. Due to the instructional content of the book, some of the topics are not covered in as much depth as they would be in a reference book.

2. Lawrence, K., A. MCRae and A. Salley. 1980. Energy Conservation Sourcebook. Aspen Systems.

This book contains many topics concerned with energy management policy rather than the quantitative side of energy management. Among the topics covered are energy trends, government involvement, and industry programs. The text also contains reproductions of sample reports. There are also some worked examples given, but no homework problems.

3. Mahon, H. P., M. G. Kiss and H. T. Leimer. 1983. Efficient Energy Management. Prentice Hall, Englewood Cliffs, New Jersey.

This book was written for plant engineers as well as students. Topics include management decisions, heat recovery and cogeneration, and energy-saving examples. There is a complete chapter dedicated to examples of various energy-management case studies. The text is easy to read with very good illustrations and checklists. The subject matter is general and not very quantitative. There are no assignment problems given at the end of the chapters.

4. O'Callaghan, P. W. 1981. Design and Management for Energy Conservation. (Pergamon Press, Oxford, New York.

Written as a handbook for plant engineers and designers, the text covers many topics concerning the scope of energy management activities, alternate energy sources, and system design. The text also reviews areas of thermodynamics as they apply to the energy conservation field. The subject matter of the book is quite technical. There are very few example problems given and no assignment problems at the end of the chapters. The text does cover a wide range of energy-related topics and would make a useful reference book.

5. Payne, G. A. 1984. Managing Energy in Commerce and Industry.

Butterworth and Company, London, England. 
This book covers economical aspects of energy management at the plant and household level. Among the many topics covered are energy auditing, combustion and heat transfer, boilers, heat recovery, and electricity. The text covers a wide range of topics and is presented in a very practical manner. Although many good ideas are presented, the text does not show how to implement the ideas. No example problems or assignment problems are given at the end of the chapters.

6. Thumann, A. 1984. Fundamentals of Energy Engineering. Fairmont Press.

This text was written as a reference book assuming the reader had no prior knowledge of energy topics. The text covers topics in economic anaTysis, energy auditing, electrical systems, waste heat, HVAC, and others. The wide range of coverage makes this book a good choice for a course text. Although the book does show some worked examples, it does not provide homework problems.

7. Thumann, A. 1983. Plant Engineers and Managers Guide to Energy Conserva-tion. Van Nostrand Reinhold Company, Inc., New York.

Written as an engineer's guide to reducing energy consumption in both new and existing buildings, the book covers many topics in the energy management field. Topics include economic decision making, electrical systems, heat transfer, HVAC, and maintenance. The book is easy to read and covers a broad range of topics. The text includes example problems but no assignment problems. Due to the breadth of the book, topics often lack detail in their explanation.

8. Turner, H. C., et al. 1982. Energy Management Handbook. Wiley and Sons, Inc., New York.

Written as a handbook for the daily practitioner of energy management, the text covers topics in boilers, waste heat, insulation, lighting, and others. Sections review thermodynamics, economics, and electricity. Because the text covers such a wide range of topics, it could be used for two energy courses. The text would also be a valuable tool after graduation. Since the book was not designed specifically as a text, onty a few examples are used; no homework problems are included.

9. Zackrison, H. B. 1984. Energy Conservation Techniques for Engineers. Van Nostrand Reinhold Company, Inc., New York.

This book concentrates primarily on electrical systems. Sections on lighting, HVAC, and controls are extensive. The text presents many practical methods of electrical energy consideration. The topics are covered in a very easy-to-read and easy-to-follow manner. Because the book concerns primarily electrical systems, no topics are presented in process energy, steam, heat recovery, or insulation. No examples or assignment problems are given. 


\section{REFERENCES}

Kennedy, Jr.,W. J., and W. C. Turner. 1984. Energy Management, PrenticeHall, Englewood Cliffs, New Jersey.

Lawrence, K., A. McRae and S. Alley. 1980. Energy Conservation. Aspen Systems Company.

Mahon, H. P., M. G. Kiss and H. J. Leimer. 1983. Efficient Energy Management. Prentice-Hall, Englewood Cliffs, New Jersey.

0'Callaghan, P. W. 1981. Design and Management for Energy Conservation. Pergamon Press, Dxford, New York.

Payne, G. A. 1984. Managing Energy. Butterworth and Company, London, England.

Thumann, G. A. 1984. Fundamentals of Energy Engineering. Fairmont Press.

Thumann, G. A. 1983. Plant Engineers and Managers Guide to Energy Conservation. Van Nostrand Reinhold Company, New York.

Turner, W. C., et a1. 1982. Energy Management Handbook. John Wiley and Sons, New York.

Zackrison, Jr., H. B. 1984. Energy Conservation Techniques for Engineers. Van Nostrand Reinhold Company, New York. 


\section{DISTR IBUTION}

No. of

Copies

OFFSITE

30 DOE Technical Information Center

$50 \mathrm{Mr}$. James Demetrops

U.S. Department of Energy Office of Industrial Programs Forrestal Building

Washington, DC 20585

15 Dr. Wayne C. Turner Industrial Engineering and Management

Oklahoma State University Stillwater, Oklahoma 74078
No. of

Copies

ONSITE

DOE Richland Operations Office

$$
\text { J. J. Sutey }
$$

15 Pacific Northwest Laboratory

B. A. Garrett-Price

N. L. Moore (5)

J. A. Shaw

S. A. Smith

Technical Report Files (5)

Publishing Coordination (2) 
